Historic, Archive Document

Do not assume content reflects current scientific knowledge, policies, or practices. 



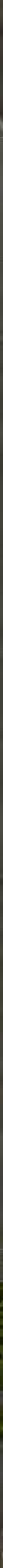




\section{Terms of Business}

Location.-General Office and Nurseries at Glen Saint Mary, Baker County, Florida, on the Seaboard Air Line Railway, thirty miles west of Jacksonville. Office and Citrus Nurseries at Winter Haven, Polk County, Florida. Office, Greenhouse and Display Grounds, Riverside Gardens, Jacksonville, Florida.

Long-Distance Telephone and Western Union Telegraph office in our main office.

Invitations to Visitors. - We take pleasure in showing our stock to persons wishing to purchase; if notified in time, we will meet visitors at the station on arrival.

No Agents.-We employ no agents, and have no connection with any other nursery. Trees sold to dealers must be resold by them upon their own responsibility. We are responsible only to parties purchasing direct from our nurseries.

Minimum Orders.-We do not care to ship orders amounting to less than $\$ 2$.

Applying Prices.-Five, fifty and five hundred trees of one class, at ten, hundred and thousand rates, respectively, purchaser's selection from varieties of one fruit having a common price. For instance, fifty or more peaches, in one or more varieties, would come at the hundred rate, and five hundred or more at the thousand rate. The foregoing does not apply to badly assorted orders, or to long lists made up of a few each of many varieties.

Terms Cash with order, if for immediate shipment. Orders for trees to be held for some weeks after the shipping season opens should also be accompanied by full payment. On orders booked in advance of the shipping season 25 per cent down, with the balance due when the shipping season opens. We do not care to ship C. O. D.

Remittances.-To secure safety and prompt acceptance, remittances should be made by Bank Draft, Express or Post-Office Money Order, Registered Letter, or Prepaid Express.

Method of Shipment.-Shipping directions should be plainly written, and we urge our customers, in all cases, to use our order sheets. We shall be pleased to forward additional ones upon application. Kindly indicate whether shipment is to be made by freight, express or mail. When method of shipment is left to us, or when no directions are given, we will ship according to our best judgment, by such means as we believe to be in the best interests of our customers.

Transportation at Purchaser's Risk and Expense.-All transportation charges are to be paid by the purchaser, and our responsibility ceases upon delivery to forwarding companies; claims for losses or damages must be made upon the latter. We will, however, start a tracer for delayed shipments, if notified, and use every means at our command to secure prompt delivery, or recovery in case of damage or loss.

Shipping by Parcel Post.-In ordering trees or plants for shipment by post, add 25 per cent to the list price, to cover cost of packing and postage.

Time of Shipment.-Unless instructed otherwise, orders received during the shipping season will be forwarded as soon after their receipt as possible, and orders booked in advance will be shipped as soon as may be after the shipping season opens.

Shipping and Planting Season.-November to March for all trees and shrubs grown in the open field; balled plants, bamboos, grasses and pot-grown plants may be shipped at any time. Shipments March to November should go by express or post.

Selecting Varieties suited to locality is of the first importance, and can often be more advantageously done by ourselves than by purchasers. We are always glad to aid our customers in their selections, when so desired, and will, upon request, cheerfully furnish additional information in regard to the adaptability or desirability of particular varieties.

Substitution. - It is our desire to furnish stock exactly as ordered. On orders for commercial planting, substitution of varieties will not be made without permission from customer. On small orders, items which we are unable to supply will be omitted unless we are instructed to substitute.

Printed Labels attached with brass wire to everything sent out.

We Guarantee all stock sent out to be well rooted, well grown, true to name, properly packed, and shipped according to instructions. Our liability under the foregoing guaranty is limited in amount to the original price received.

Claims.- - If, by any possibility, errors should occur, they will be promptly rectified, if claim is made within ten days after the receipt of the goods. 


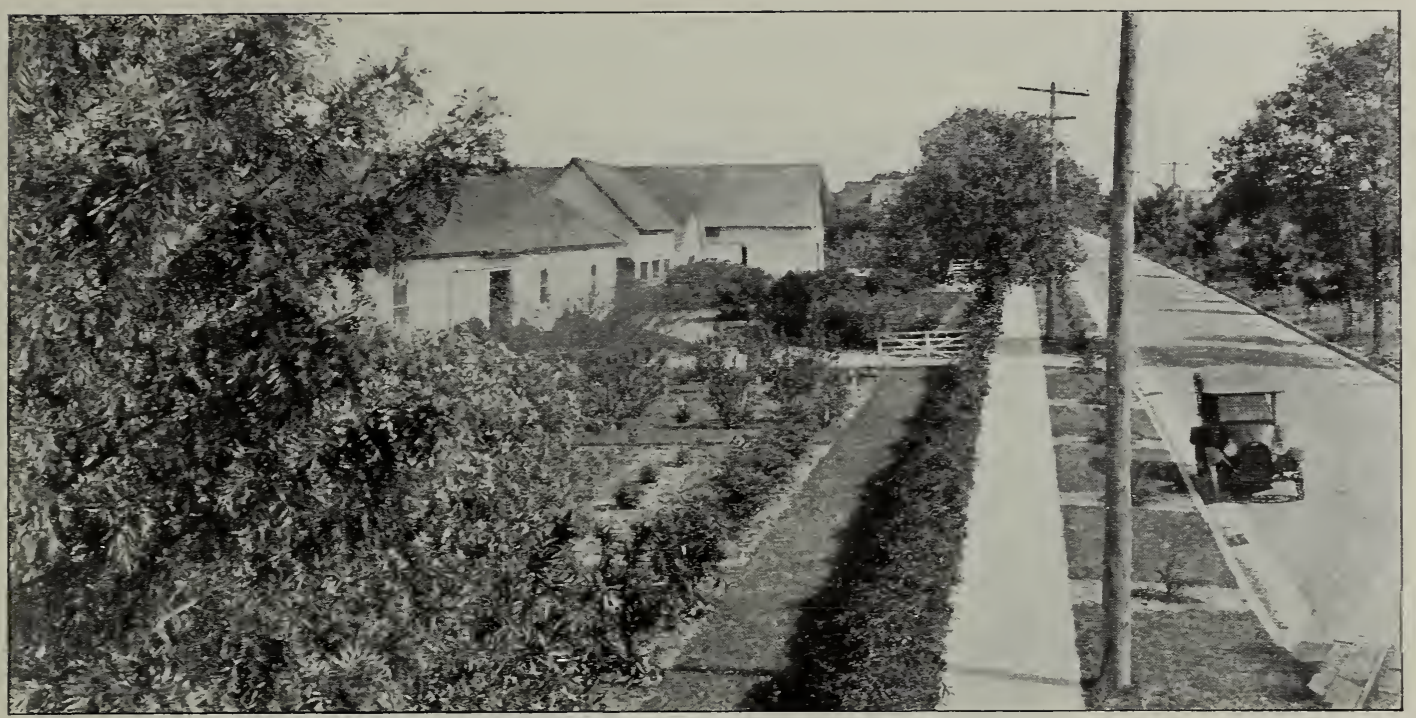

GLEN SAINT MARY GROUNDS AND PACKING HOUSE, WINTER HAVEN, FLA.

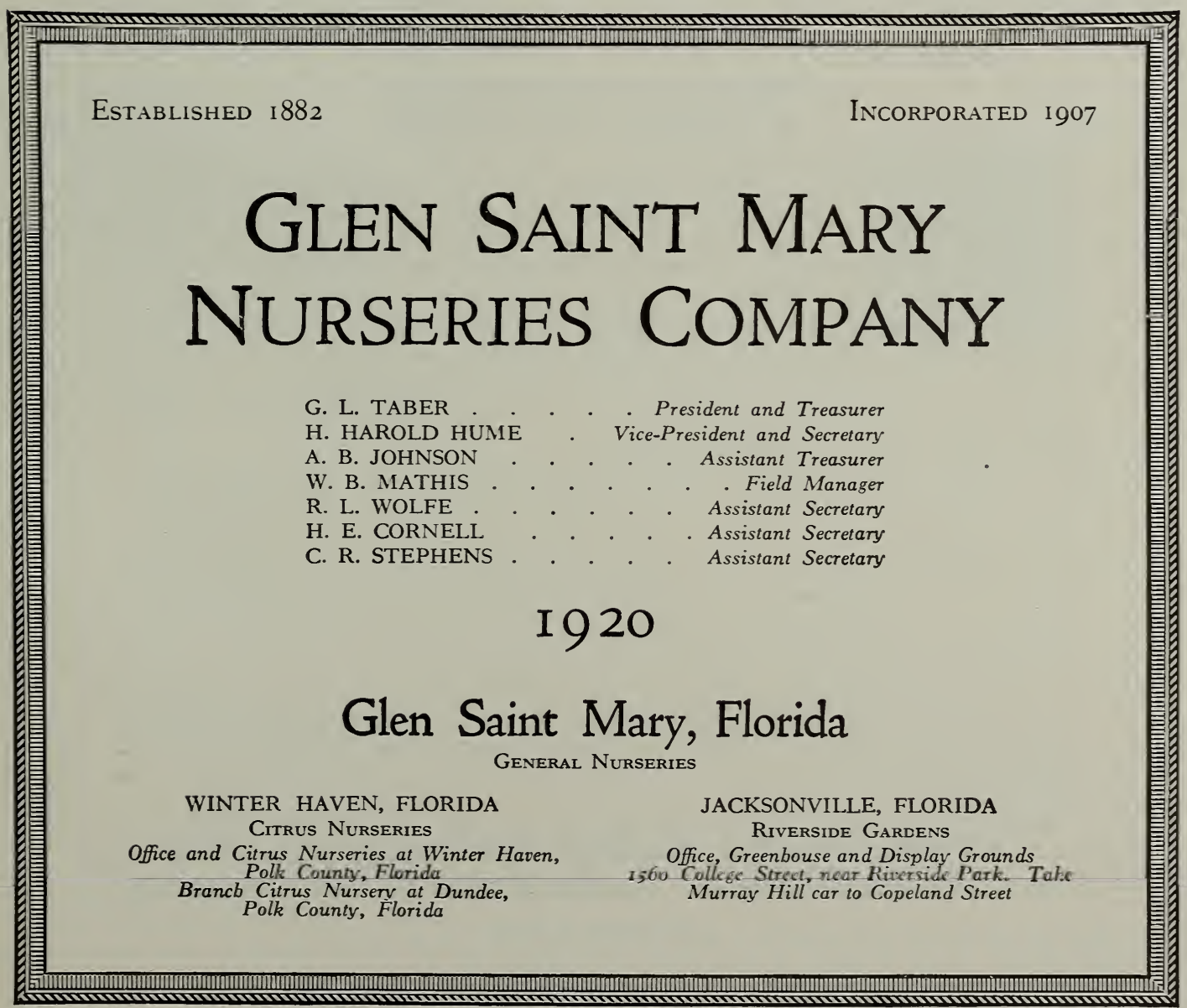




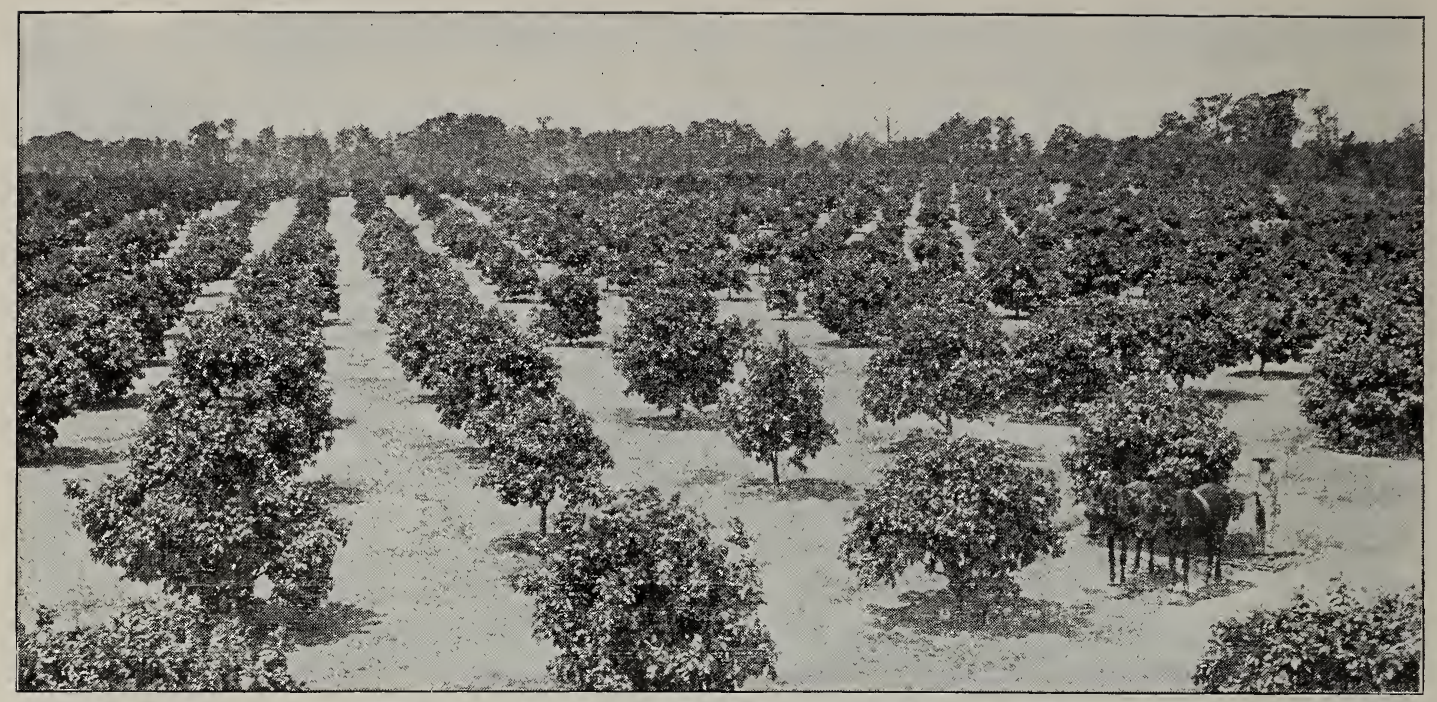

View in one of our Orange and Grapefruit groves

\section{FुOREWORD}

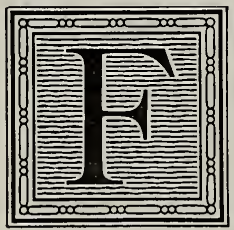

ROM April, I9I7, to November, 19I8, our country devoted its entire energy toward the winning of the world war. In this struggle, our Company did its utmost to render every service possible. In consequence, our usual output was curtailed, and we were unable to meet the requirements of all our customers. But now that peace has come, we are again devoting ourselves with renewed energy to the work of furnishing, to the treeplanting public, trees and plants of the quality for which our nurseries have been long and justly famous.

Thirty-seven years of painstaking nursery work have placed us in a position to meet the requirements of the most exacting, and today the products of the Glen Saint Mary Nurseries are regarded as standards of quality. This quality has been steadily maintained, and, under the general improvement in conditions of transportation and Iabor, we will be able to furnish in larger quantities than have been possible during the last two or three seasons.

In the confidence that our trees and shrubs will give the same satisfaction that through many years has secured new customers and held our old ones, we solicit the opportunity of furnishing your requirements.

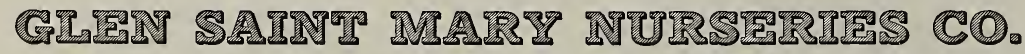
(G. Ia 捾A

October I, I9I9 


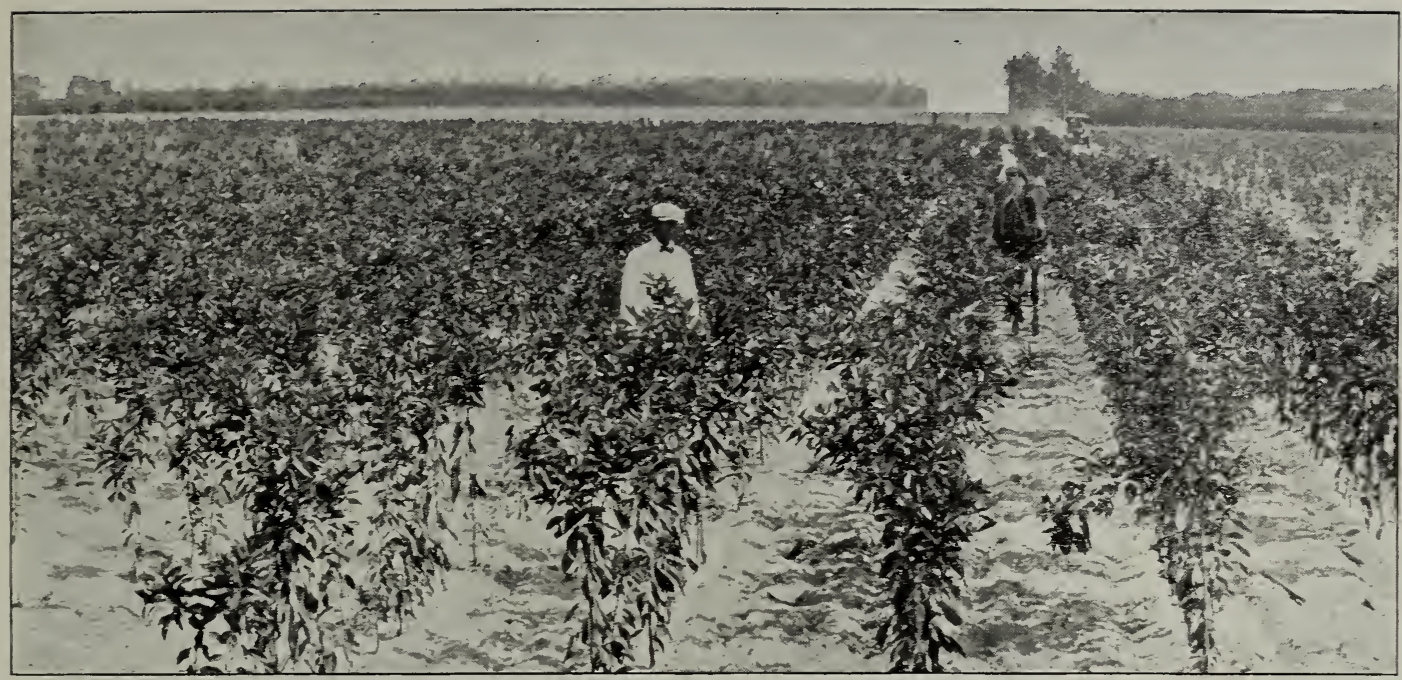

Citrus trees in our Nursery, Winter Haven, Florida

\section{Citrus Fruits}

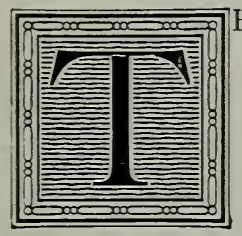

HE GLEN SAINT MARY NURSERIES COMPANY has for a great many years grown by far more citrus trees than any other nursery in the world. While we do not grow citrus trees exclusively, producing other nursery trees as well, still the growing of citrus trees has always been the paramount and largest interest of our nursery business. Words like "largest" or "biggest" do not necessarily mean much to a prospective buyer until he stops to consider that the reason for this largeness is nothing more or less than the result of a continued and ever-increasing demand for stock that has absolutely made good with our customers in every sense.

It is the purpose of this section of our catalogue to present to our customers a precise description of the citrus nursery stock we grow. It is not our purpose to give a history of the citrus industry or to write a complete treatise on the culture of these fruits. The subject is too broad and extensive to permit of our doing this.' The prospective planter has a general knowledge of the business, gained by association with it in some of its phases, and our thirty-seven years of experience in it are entirely at his command by personal visit or by mail.

We ourselves are deeply interested in growing Citrus Fruit. We know it to be a profitable business and we are constantly adding to our own plantings. During the past several years the prices of Citrus Fruit have steadily increased and the demand has at the same time more than kept pace with the supply. There is absolutely no danger of overproduction and at this time the growing of Citrus Fruit commercially is, we believe, a safe and profitable industry.

Sour Orange, Rough Lemon, and Citrus trifoliata seedlings used in our nurseries are grown in our own seed-beds, thrifty, vigorous, well grown, carefully selected and graded at time of setting in the nursery rows. They have not been forced beyond their normal growth.

After transplanting in the nursery rows, the stocks are carefully fertilized and cultivated according to the methods worked out in the thirty-seven years of our nursery experience. Needless to say that, in this period of time, we have learned how to grow the very finest nursery trees that can be produced. That our customers agree with us is evidenced by the annually increasing volume of our business. These years of experience are of untold value to our customers.

We know the comparative value of different sorts because we are growing them in our test orchards. in these orchards the largest-known collections of Citrus Fruits are to be found. For instance, at the meeting of the American Pomological Society in Washington, in November, I9I3, we exhibited eighty-three varieties of Citrus Fruits of our own growing. We venture to say that no such collection of Citrus Fruits grown by one firm was ever before brought together. Not all of these varieties are, of course, offered in our lists; but the best, as determined by actual test throughout the citrus districts, are propagated.

The varieties we are propagating are selected strains, with a straight-line history going back to an individual tree of known merit. In our propagation work, care is taken to select well-developed 
Citrus Fruits

buds from trees of authentic parentage, thus making sure that the young trees are true to namequality trees in every particular.

At the time the trees are sold, the roots of one-year trees are four to five years old. The age of the root has an important bearing on the established character of the trees, as well as on the time the trees will come into bearing.

We grow and furnish varieties of citrus trees on different stocks to suit conditions wherever Citrus Fruits are grown throughout the world. We supply trees for Florida, the Gulf Coast, Mexico, South and Central America and have made shipments to the more remote citrus-growing areas in South Africa, the Philippines, Egypt and elsewhere.

\section{STOCKS FOR GITRUS TREES}

To one not familiar with the industry, about to plant Citrus trees, the question of which stock to use must seem very perplexing. So many apparently conflicting claims for and against this or that root system are made. However, it should be remembered that the knowledge of an individual grower, unless he be a very extensive one, possibly may not extend beyond his own grove or his own immediate locality. Our experience and observations of many years embrace the entire citrus area.

Citrus trees can be grown on roots of any member of the whole citrus family. We have tried a great many of them. Most of them, for one cause or another, are not adapted for citrus fruit culture under general conditions. We have found that practically all requirements for success under different climatic and soil conditions can be met with Sour Orange, Rough Lemon, or Citrus trifoliata stocks.

Instead of being difficult to arrive at, we believe the choice of stocks almost imperatively settles itself. Each of the three stocks on which we grow Citrus trees possesses distinctive marked characteristics as well as adaptability to the location in which it should be used. Successful, heavy-bearing, beautiful groves are produced from trees on all of these stocks. But no one of them will meet all conditions. It is largely a matter of soil, location and climatic conditions.

Some varieties of citrus grow equally well on all stocks, under proper conditions. Others are failures. Our extensive experience has taught us which varieties do not fully succeed on certain roots and our customers may rest fully assured that the varieties we offer are well adapted to the different stocks on which they are grown.

ROUGH LEMON. This stock has a decided influence on the variety or top worked upon it, especially as affecting its growth and degree of hardiness. Rough Lemon is the thriftiest growing of all stock and induces a vigorous growth of top. On account of its wide-spreading root system and very thrifty growing characteristics, it is the best stock for light sandy soils. Trees worked on it do well on soils so lacking in fertility that other stocks would be complete failures. On account of its rapid, vigorous growth, trees on Rough Lemon stock are more tender than when propagated on other stocks and should be planted where there is little or no danger from cold. As a rule, light sandy soils such as are found on the lower East Coast and in the high rolling regions of Polk, Orange and Lake Counties are fairly immune from frosts, and to this type of soil the Rough Lemon stock is best suited.

SOUR ORANGE. No stock on which citrus fruits are produced is more widely used than Sour Orange; no stock is better adapted for the production of healthy, vigorous trees and fine quality fruit under a wide range of soil and climatic conditions. It is safe to say that the bulk of the world's citrus fruit crops are grown on this stock. The first budded groves in Florida were grown on Sour Orange roots and this stock is being used almost entirely in all of the other citrus-producing sections of the world. It is a deep-rooted stock, healthy, free from disease and hardy. It is adapted to the heavier soils such as good flat woods land, hammock and muck, and on these lands produces fine, vigorous trees. For the production of high-quality, late-keeping fruit it is unsurpassed.

CITRUS TRIFOLIATA. This is the hardiest species of citrus known in this country. It has become of great importance as a stock for Citrus trees of all kinds. Varieties budded on it are made hardier because of its dormant and hardy character, and the fruit is of exceedingly fine quality, ripening two or three weeks earlier than if budded on other stocks. It has been claimed that it dwarfs the trees budded upon it, but the tests of years in our test groves have not proved this to be so, except in the case of a few varieties. For the Satsuma Orange, it is the only stock to use, because of its influence on the quality of the fruit and the fruitfulness and hardiness of the tree. It is adapted to planting on alluvial lands, clay lands, soils underlaid with clay, and those which naturally contain plenty of moisture or to which water can be applied by irrigation. It should not be planted on high, dry, sandy lands lacking moisture. On such soils it is a failure. It is the stock which should be used for Citrus trees in most parts of northern and western Florida, Alabama, Mississippi, Louisiana, and in Texas as far south as Beeville. In some parts of this territory Sour Orange stock is recommended. 


\title{
GLEN SAINT MARY NURSERIES
}

\author{
Citrus Fruits
}

\section{VARIETIES PROPAGATED ON DIFFERENT STOGKS}

Some varieties are more successfully grown on certain stocks than on others. Having this in mind, as well as certain other features, we do not attempt to grow or to offer to our customers citrus nursery trees of every kind budded upon each of the three stocks. It sometimes happens of course that a variety on one of the stocks is sold out, in which case it cannot be supplied until the next season. For this season's trade we have propagated the different varieties as follows:

\section{VARIETIES ON ROUGH LEMON STOCK-}

Oranges: Homosassa, King, Lue Gim Gong, Parson Brown, Pineapple, Ruby, Tangerine, Valencia. Grapefruit: Duncan, Marsh Seedless, McCarty, Silver Cluster, Triumph, Walters.

Lemons: Ponderosa, Villa Franca. Limes: Tahiti.

Kumquats: Marumi, Neiwa, Nagami.

VARIETIES ON SOUR ORANGE STOCK-

Oranges: King, Lue Gim Gong, Parson Brown, Pineapple, Ruby, Tangerine, Valencia, Washington Navel.

Grapefruit: Duncan, Marsh Seedless, McCarty, Silver Cluster, Triumph, Walters.

Lemons: Ponderosa, Villa Franca.

VARIETIES ON CITRUS TRIFOLIATA STOCK-

Oranges: Homosassa, Parson Brown, Pineapple, Satsuma.

Grapefruit: Duncan. Kumquats: Nagami.

PRICES ON ALL VARIETIES OF CITRUS, EXCEPT KUMQUATS.-On Sour Orange, Rough Lemon and Citrus trifoliata stocks.

Each Per Io $\$ 5$ I0 I00 $\$ 50$ oo $\$ 450$ oo in color, roughened and pitted on the . tith a rather thick rind The flesh is $\ldots \ldots \ldots \ldots \ldots \ldots \ldots \ldots, 80$ : in color, quality excellent, with a spris ble flavor in which sweet and subacic 7 oo 65 o0 600 o0 9 o0 85 o0 800 o0 II 50 IIO OO I, 000 OO $\ldots \ldots \ldots \ldots \ldots \ldots$ I 75 I6 oo I40 o0 1,250 oo

Satsuma, Tangerine, King and Limes caliper somewhat less than the measurements given above on account of their more slender growth. All Citrus trees are pruned for planting before shipment.

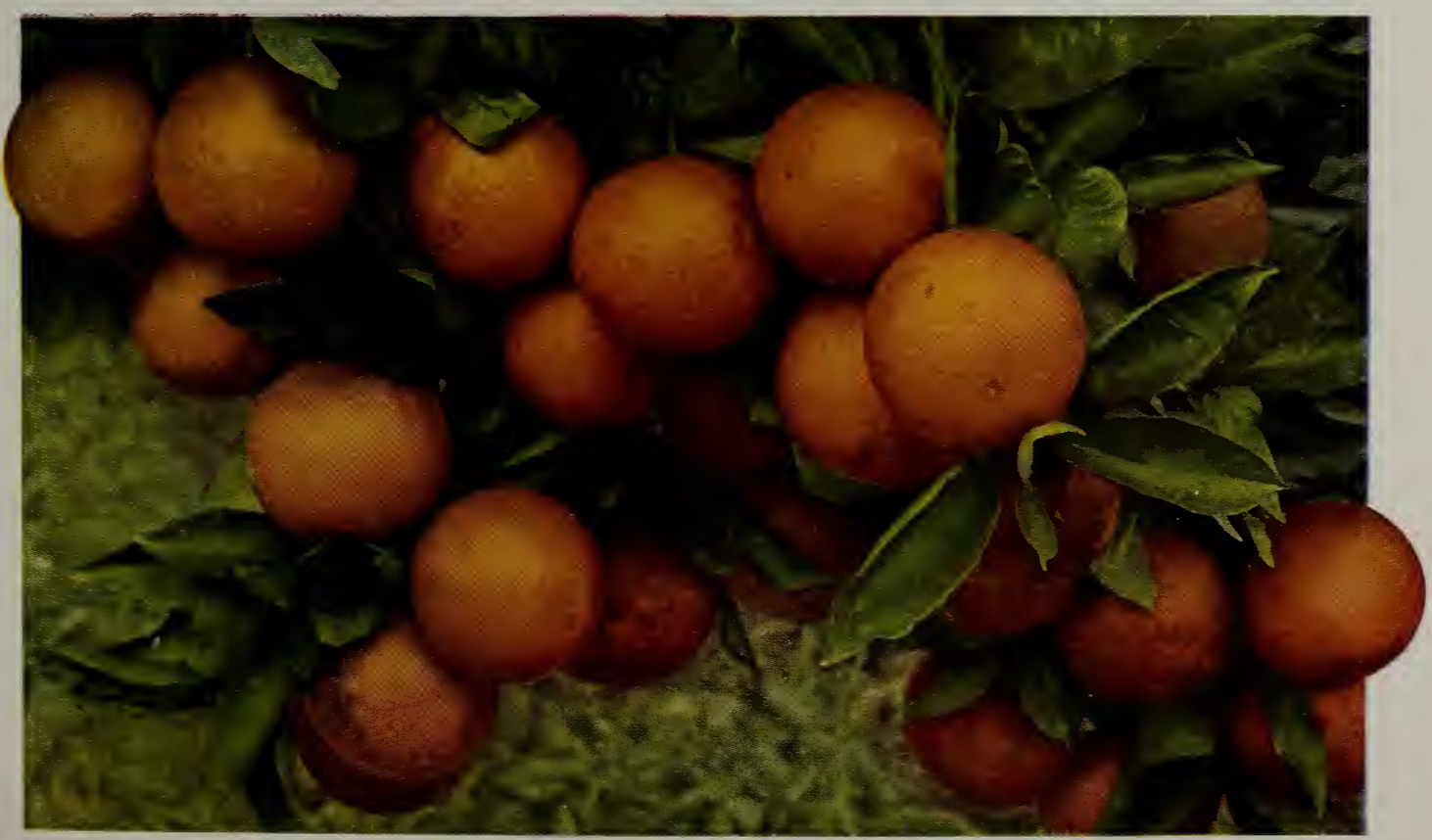

Pineapple Orange 


\section{SOUTHERN Planting FACTS}

Citrus Fruits

\section{ORANGE}

Since the very earliest days, the Orange has attracted the attention of fruit growers and fruit consumers. Today it is one of America's most important fruit crops and based upon it an enormous industry has been built up, and in addition to its importance in commerce, it has lost none of the charm that has come down to us from ages past.

From time to time during the period which has brought the Orange to its present important place in industrial development, it has been prophesied that too many trees were being planted, that the fruit supply would so outrun the demand that producers would not receive satisfactory returns from their crops. In moments of pessimism, many have been guilty of such predictions. Yet, they have not come true, and looking at the matter broadly it is a safe venture to say that such a condition will never come about.

So far as our markets are concerned, the United States and Canada are one, with a population of one hundred and twenty-five millions. Last season, Florida's citrus production was approximately eight million boxes. This includes both Oranges and grapefruit, other kinds being produced only in negligible quantities. Allowing one hundred and fifty-six fruits per box, which, counting grapefruit, is certainly a liberal basis, we produced only enough to supply each one of our possible consumers with ten fruits. This of course for Florida's production only. Certainly there is no reason to be alarmed over our production if the distribution of the crop is handled properly. More than that, there is no immediate chance of increased plantings increasing the number of fruits per person, because of the natural increase in population. In this relationship of population and production lieș the most satisfactory answer to any possibility of over supply. But ts trees possesses distinctive marked c, so that

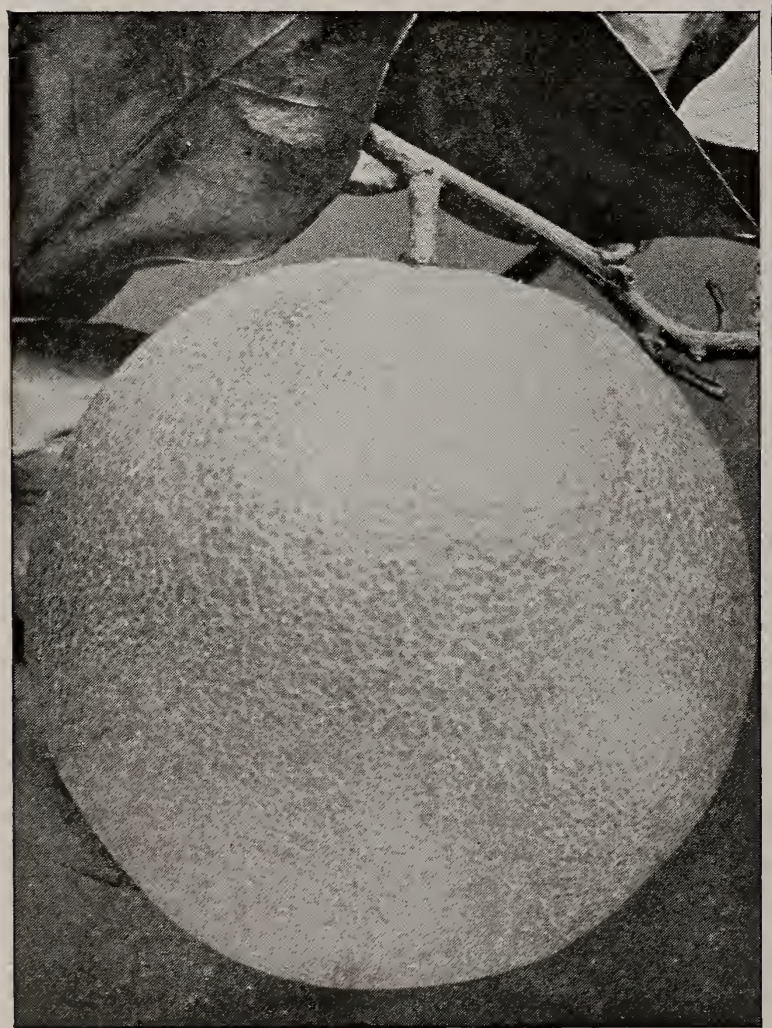

Homosassa Orange it should be used. Successful, heavyal comese stocks. But no one of them will ment of climatic conditions.

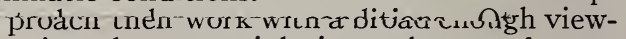
point, there certainly is no danger of overproduction.

Having this in mind, the Orange grower of today, considering the limited areas in which the crop can be successfully grown, can certainly look forward with confidence to the future of the industry in which he is engaged.

There was a period in the development of Orange growing in Florida when a very large number of varieties were propagated by nurserymen and set out by planters. Year by year, however, as the industry became stabilized their number has decreased until at the present time the list is confined to a sufficient number of varieties to adequately cover the fruiting season with a few special varieties to meet special conditions and special tastes. The list of standard varieties of Oranges which we are propagating for our customers cannot be improved upon and when a planter has decided upon the season at which he desires to market his crop, the question of varieties to plant is easily settled.

With the establishment of our nurseries in I 882 the propagation of the Orange was undertaken. We have seen many varieties come and go. For thirty-seven years we have been growing citrus nursery stock. Naturally during these years we have learned much, and our work today is backed by an intimate knowledge of how to grow good Orange trees that is of the utmost value to our customers. 


\section{GLEN SAINT MARY NURSERIES}

\section{Citrus Fruits}

\section{Homosassa Orange}

This is a real Florida Orange, a direct descendant of the early varieties introduced by the Spaniards. It is no hothouse variety, but a sturdy, dependable sort. Candidly we do not believe there is a variety of Orange in Florida that will outbear it, and it is the best we know of for its season-late November to early January. For marketing at this season, no mistake can be made in planting it. The fruit is of large size-remarkably so, considering how heavily it yields-orange-yellow in color, with thin, smooth, tough skin. Its flavor is sprightly, rich, and vinous; the juice is abundant; the quality excellent. It is a good shipper and it was with Oranges such as this that Florida's reputation as an Orange-producing state was established.

\section{King Orange}

The King Orange is the latest-maturing of the Mandarin (sometimes called the Kid-glove) group. It is ready for marketing in March and April. The fruit is of large size, flattened, deep orange in color, roughened and pitted on the surface, with a rather thick rind. The flesh is deep orange in color, quality excellent, with a sprightly agreeable flavor in which sweet and subacid are well blended. The tree is an upright grower, with very dark green, shiny foliage. It is a very prolific

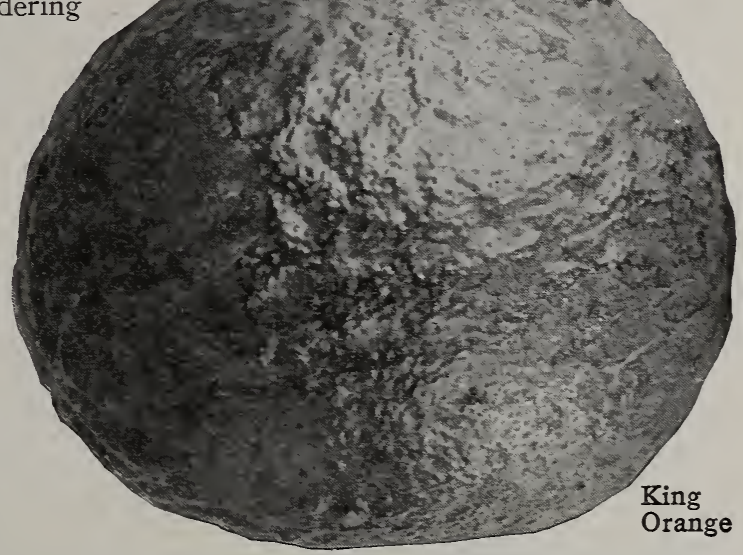
sort and this, together with its late-ripening season and high quality of fruit, have combined to make it a very profitable variety. It always commands a high price in the markets. In any mixed orchard it is well worth planting, and it has a place in every home grove. This side of citrus fruit culture is very often lost sight of. Our whole attention is so often given solely to our commercial work that we lose sight of fruits to be grown for home use, and which add so much to the comfort and joy of living.

\section{Lue Gim Gong Orange ( $\left.\begin{array}{c}\text { See illustration } \\ \text { page } 8\end{array}\right)$}

In 1886, Mr. Lue Gim Gong, a Chinaman, in his grove near DeLand, Fla., pollinated Hart's Late flowers with pollen from what was believed to be a Mediterranean Sweet Orange. An Orange resulting from this cross contained fifteen to eighteen seeds, and from these seeds twelve trees were raised, no two of which proved to be the same. One tree, the variety now known as Lue Gim Gong, when it came into fruiting, proved to be a decided improvement over Hart's Late, in fact, was a fruit quite out of the ordinary. From observations extending over a period of several years, it was found that in addition to being an Orange of fine appearance, of exceptionally good flavor and quality, it did not ripen until extremely late in the season; in fact, it was not fully ripe until several months after Hart's Late. Also, it was found that the fruit hung on the tree throughout the summer months with very little dropping. So convinced were we of its merits, that we entered into a contract with Mr. Lue Gim Gong for the exclusive right to undertake the propagation of the new Orange. Convinced that the Lue Gim Gong possessed merit in many particulars which placed it in a class by itself, we offered it to our customers for the first time in August, I9II. Several of our largest customers planted heavily of it and now report to us that it has proven out fully the splendid qualities we knew it possessed. In our own commercial groves we now have many acres of bearing trees of the Lue Gim Gong Orange. The most noted horticultural organization in the country today, as it has been for the past sixty years, is the American Pomological Society. This Society, recognizing the merits of the Lue Gim Gong Orange, awarded a Wilder Silver Medal to this variety. We believe this is the first time a Wilder Medal has been awarded for a new variety of Orange since the Society was organized, and gives a fair idea of the estimation in which this fruit is held by experts.

The Lue Gim Gong Orange is an established commercial success. Based on reports from our customers, and upon the behavior of bearing trees in our own groves, we give the following information: In size, the fruit is large, packing 126 to I 76 per box; in form oblong, carrying its full diameter well 


\section{SOUTHERN PLANTING FACTS}

\section{Citrus Fruits}

\section{Lue Gim Gong Orange, continued}

down to the rounded base. The color is a deep orange-red; skin smooth; sections ten or eleven in number; flesh deep orange, very juicy, and free from rag. The flavor is a rich blending of sweet and subacid and, when fully ripe, of delicious, unsurpassed quality. It is nearly or quite seedless. The fruit is a good keeper and fine shipper and in itself is very hardy and resistant to cold.

Lue Gim Gong trees are hardy, thrifty growers. In our own groves and nurseries we have observed during several cold snaps that trees of this variety invariably suffer less injury than any other variety of round or sweet Orange. With us there is no question but that it is the hardiest of the sweet Orange group. This statement is amply borne out by the observations of many growers under widely different conditions.

The tree is a good bearer, the equal, if not the superior of any late Orange in this particular. It is a regular bearer, and this is very unusual, for in the case of most late varieties, if the Oranges are allowed to hang on the trees until late in the season, the crop following will be light. It produces a low, well - rounded head, spreading rather than high and upright, and is the thriftiestgrowing variety of all the Orange trees we know.
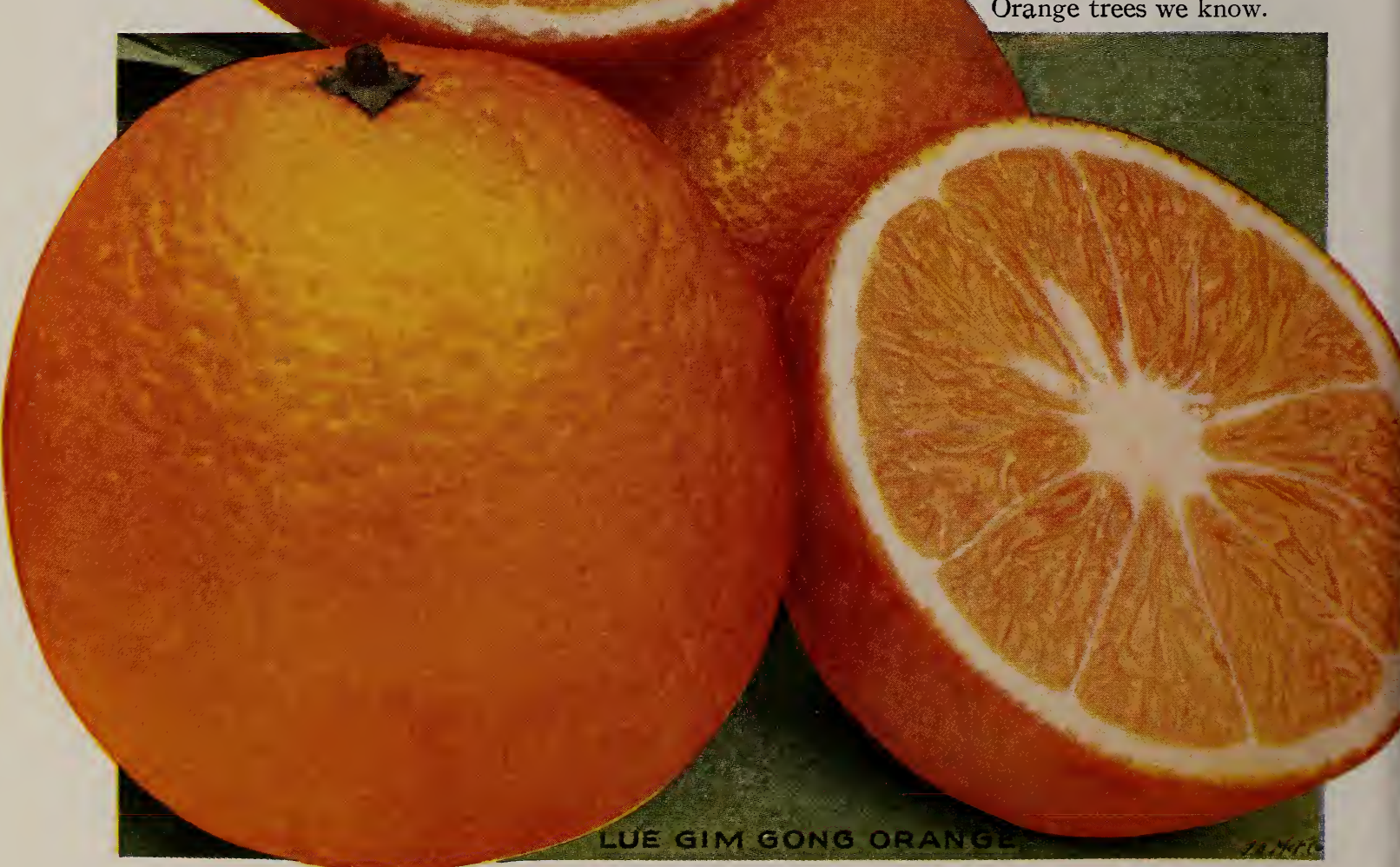


\section{GLEN SAINT MARY NURSERIES}

\section{Citrus Fruits}

\section{Lue Gim Gong Orange, continued}

The fruit is edible in March and April, but is then too acid for most tastes. It begins to ripen in June, and from then on is delicious. It will hang on the trees for months, but for all practical purposes would be marketed as a remarkably late Orange for one year, say in June or July, or as an exceptionally early one for the next season, in September or October. Certainly there is no risk of violating the green-fruit law when shipped at the later dates. From our own groves, Lue Gim Gong has brought us splendid prices and now, with our complete knowledge of the variety, we unqualifiedly recommend it for commercial planting as a remarkable money-making Orange.

\section{Owari Satsuma Orange}

For many years it was believed that there was but one Satsuma Orange. The investigations of Dr. T. Tanaka. however, have shown that in Japan there are at least a half dozen well-marked varieties of Satsuma, with still others showing minor distinctions. A careful investigation of Satsuma orchards has been made in America by Dr. Tanaka and Mr. Leo. B. Scott, of the United States Department of Agriculture. They found that three strains of Satsuma have been unknowingly mixed together, propagated, sold, and planted. The result in the bearing orchards is most unsatisfactory, as the resulting crops are not uniform in size, quality, or time of ripening.

When the propagation of Satsumas was undertaken by the Glen Saint Mary Nurseries (trees were first offered for sale in I888), but one single introduction was made. The propagating material of this strain came from Maj. O. P. Rooks, Fruitland Park, Fla. To this single introduction, all our subsequent propagations trace back. Orchards planted with Glen Saint Mary trees throughout the Gulf Coast country became noted for the fine, large, uniform, early-maturing crops of fruit they produced. An investigation made by Dr. Tanaka and Mr. Scott has shown that our trees in orchard and nursery consist of a pure strain-Owari Satsuma. This is the variety most commonly grown in Japan, where it has practically supplanted other strains. Through all these years-the past thirty-one years to be exact-this is the variety we have furnished our customers. This is so as the direct result of our policy of line propagation, beginning with a definite specimen of known worth. The fruits of Owari

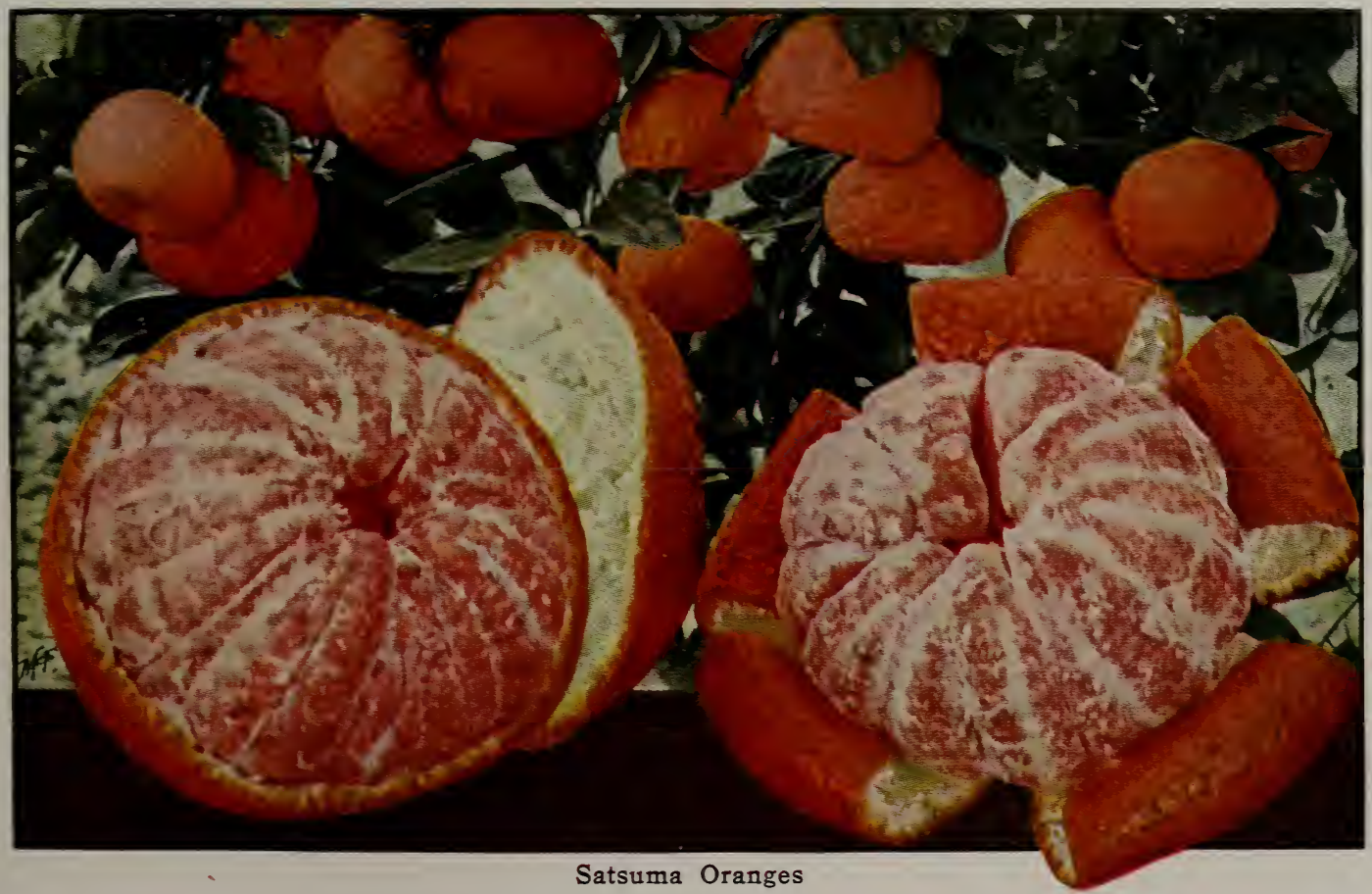




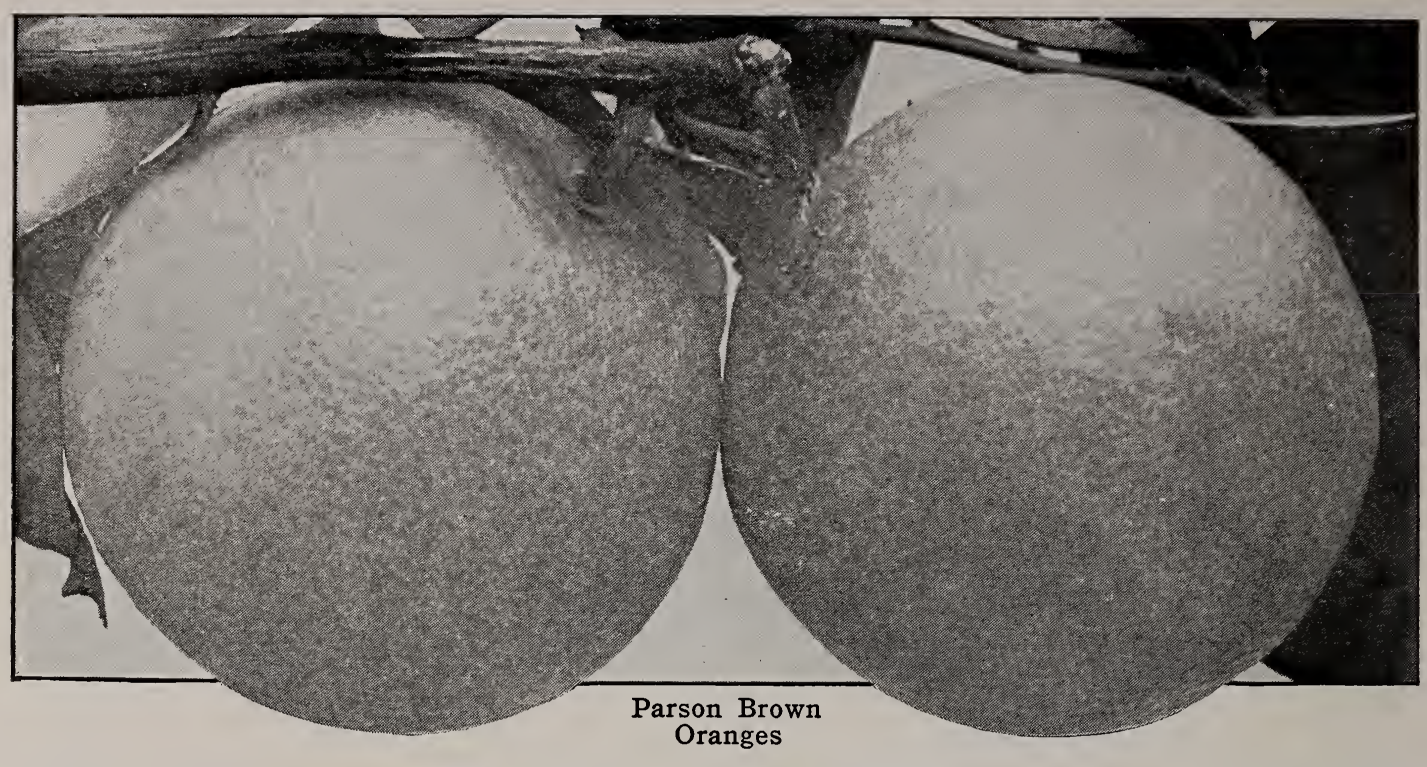

\section{Owari Satsuma Orange, continued}

Satsuma are large, flattened, depressed at both stem and blossom end, deep orange in color, with thin smooth rind, which may be stripped from the pulp with the fingers without breaking the sections into which the fruit is divided (see illustration), and nearly or quite seedless. No citrus fruit that we know of surpasses a well-grown, well-ripened fruit of Owari Satsuma from our orchards. Trees of this strain are thornless, prolific, vigorous, rather upright growers. For years we have marketed our crop during October and early November, though sometimes we have shipped in September. Owari Satsuma is an extremely hardy tree, having gone through I 5 degrees Fahr. without injury, and its natural hardiness is increased by budding on Citrus trifoliata stock. This is the only stock adapted to it, the only one on which we grow it. Young trees are heavy bearers, and under proper conditions an orchard of this variety brings early returns on the investment. It is particularly adapted to west Florida, southern Georgia, Alabama, Mississippi, Louisiana, and the Gulf Coast country of Texas. In this section Owari Satsuma should have a place in every home orchard, and in many sections it is a high-class commercially profitable orchard fruit. In the fall of I9I8, Owari Satsuma fruit registered a new high price level of $\$$ I2.60 per strap.

\section{Ruby Orange}

A valuable variety, and, when well grown, it is not too much to say of Ruby that it is a standard of quality. This Orange came from southern Europe. It does not, like most Oranges, possess marked acidity, so can be shipped and eaten early in the season, November and December. As the fruit hangs on the trees longer, however, its full, rich flavor develops, the skin usually becomes streaked or mottled over with red, and toward the end of its season, about March, the entire pulp often becomes blood-red. The fruit is of medium size, about I 76 to the box, usually somewhat flattened, skin thin, very tough; pulp melting, rich, juicy and of exquisite flavor; quality unsurpassed. Ruby on Rough Lemon root is earlier and its season not so long as when grown on other stocks. The tree is a good grower, dense foliaged, thornless, and a regular, prolific bearer.

\section{Parson Brown Orange}

Many early Oranges have been tried out, but of all these only one remains that can at this time be considered. It is not all that might be desired, but Parson Brown is, so far, the best early Orange that has been grown on a commercial scale. And it has made money on the early market, since it is the earliest variety that will stand the government acid test. Our strain of Parson Brown goes straight back to the original source, and we have been growing it in orchard and nursery for more than twentyfive years. We have selected and reselected it from bearing trees until we know there is no better Parson Brown than the old Carney Parson Brown, Glen Saint Mary-selected and -grown. It was introduced about $\mathrm{I} 878$ by Capt. J. L. Carney, of Lake Weir, Fla., and soon attracted attention because of its early ripening habit and other desirable features. The fruit is of medium to large size, of good quality, and is ready for market in November or sometimes in October. For early market, it is the best early Orange to plant. 


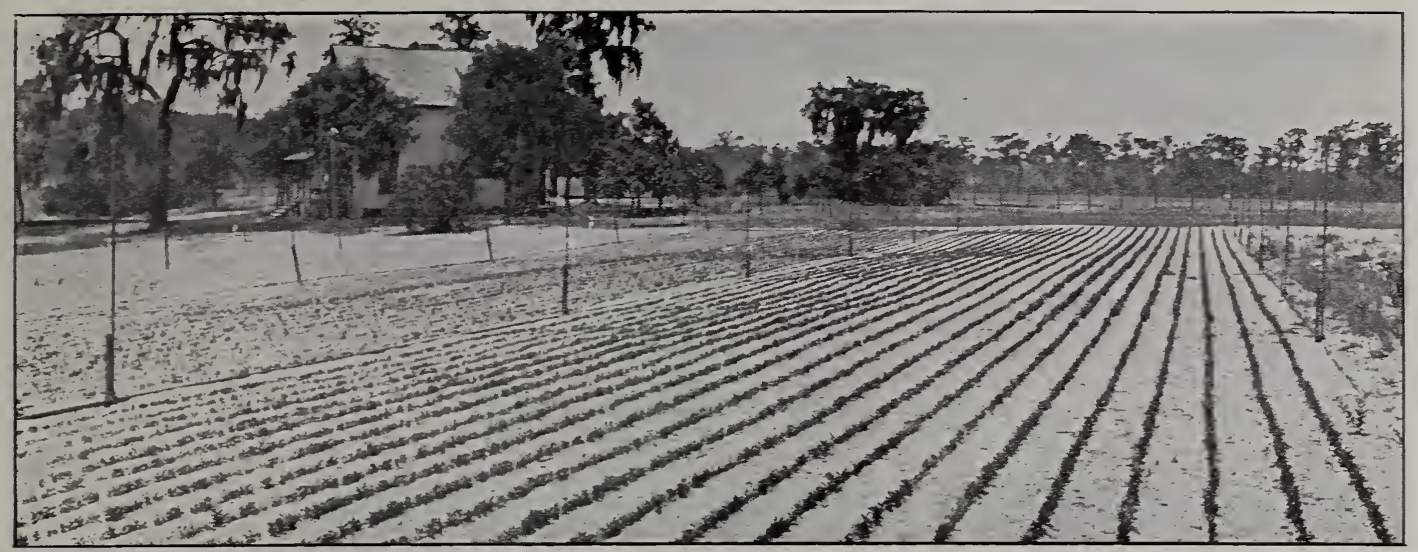

Seed-bed at Dundee, Fla., where our stocks are started

\section{Pineapple Orange}

The fame of this variety was established many years ago, and of all the Oranges which have originated in Florida it has been most largely planted. It often happens that varieties in favor at one time are later supplanted by others, but this has not been the case with Pineapple. No orchard planting today is contemplated without considering this variety, and we venture to say that so long as Oranges are grown in Florida the Pineapple Orange will make up a generous part of the output. It originated in the heart of the old citrus belt of Florida, near Citra, in the grove of Dr. James B. Owens. Because of its peculiarly fine flavor and its fancied resemblance in flavor to a pineapple, it was so named. The fruit was first marketed in quantity by Bishop, Hoyt \& Co. It soon established a reputation, a reputation it has maintained and increased from year to year.

The fruit is of good size, a deeper, richer red in color than any other round Orange we know. Of course, it has to become well ripened before its full color develops, and in some localities it takes on higher color than in others. In quality it is unsurpassed, its flavor being a rich blending of sweet and subacid peculiar to the variety, and it not only resembles the pineapple in taste but also in odor. Pineapple Orange trees bear well. For its season, January to February. it has no superior. Groves planted to this variety are among the most profitable in Florida, and wellgrown $\mathrm{P}$ ineapple Oranges will always command high prices. See illustration in natural colors on page 5 .

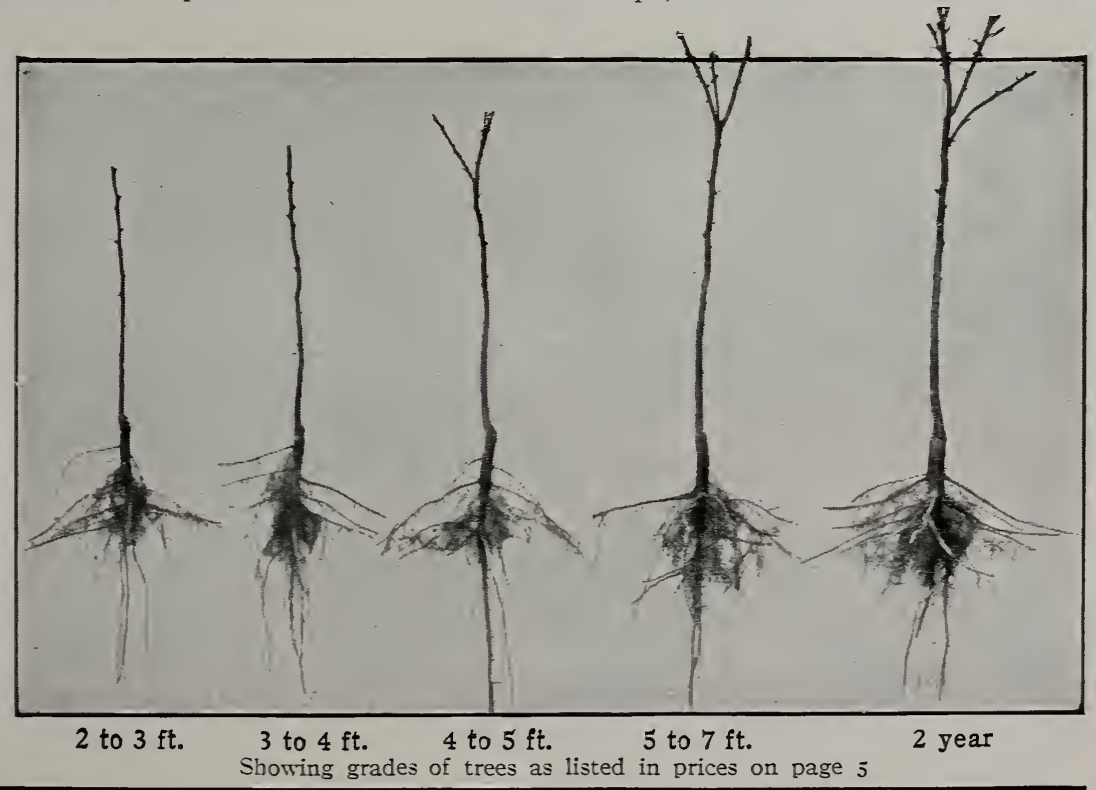

We are the largest growers of citrus trees in the world, and have been for many years, which is an indication that our stock has always measured up to our descriptions of it. Fruit-growing is a profitable business for us and will be for you if you plant the thrifty, vigorous trees such as we supply. Prices are steadily increasing and the demand is always ahead of the supply. 


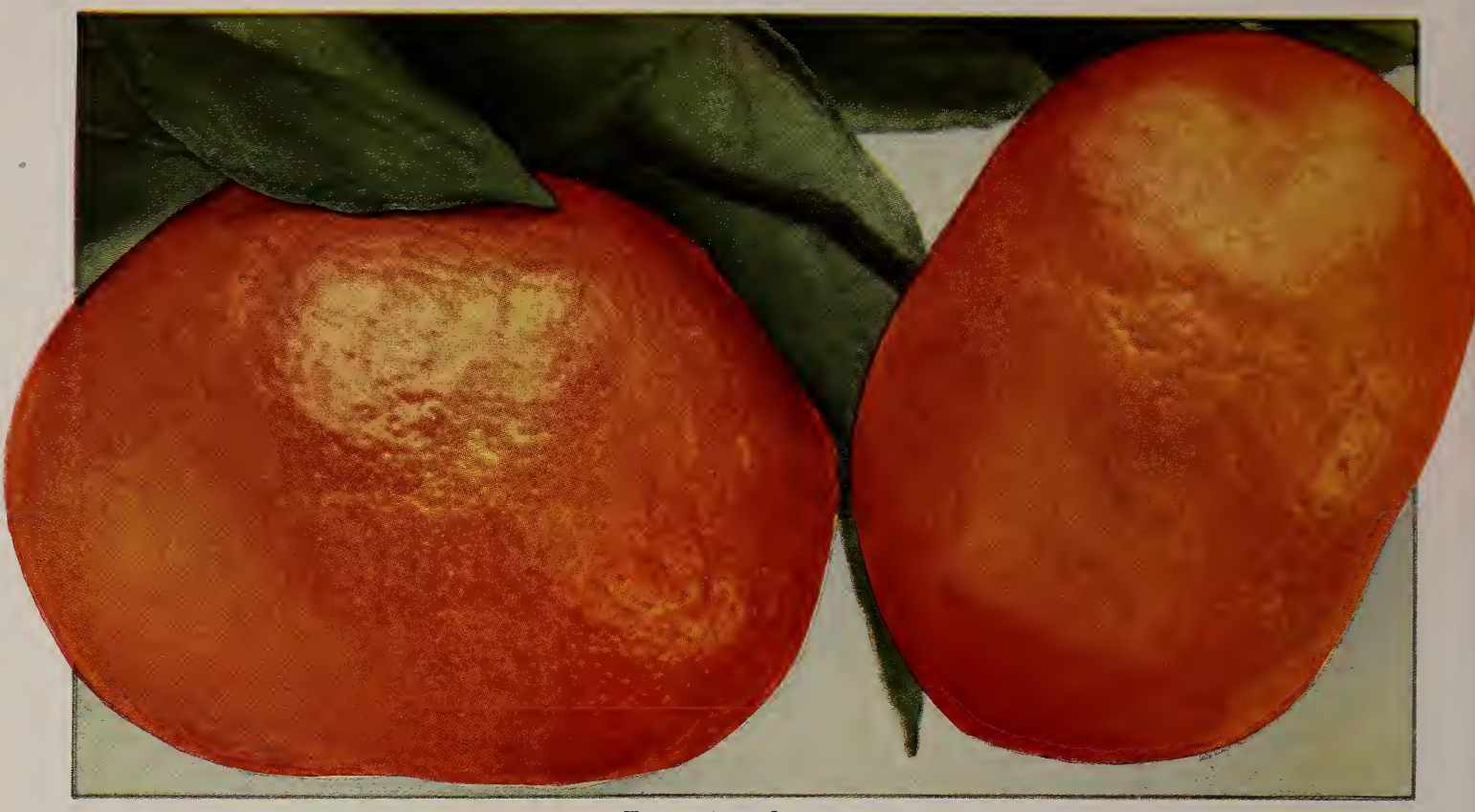

Tangerine Oranges

\section{Dancy Tangerine Orange}

This Orange, a "kid-glove" Orange by the way, is so often referred to as a fancy fruit that its real value as a straight money-making variety is often lost sight of. Plantings of Tangerines have proved to be very profitable, and quantities now produced are always marketed at good profit. Moreover, it ripens and is ready for market when its extremely high color lends most value to its sale.

The tree is compactly headed, dense, and rather upright, but tending to spread as it grows older, the head being opened by the weight of heavy crops of fruit. It is a very ornamental as well as a wonderfully prolific variety. This feature has been further increased in Glen Saint Mary trees by the careful attention we have given to its propagation for many years. The fruit is flat, of medium size, with very smooth rind and very high color; a brilliant deep orange-red, almost tomato-red, sets it in a distinct class from all other citrus fruits. The flesh is dark orange in color, with melting pulp, very free from fiber, and filled with delicious juice. Like Satsuma and King, the skin is very easily removed and the sections readily separated without breaking the juice sacs or soiling the fingers. Dancy originated in Florida, at Buena Vista, in St. John County, the original tree being raised by the late Col. G. L. Dancy, and it was brought into cultivation about $187 \mathrm{r}$. For the grower who desires to produce a high-grade fruit that is just a little out of the ordinary, Dancy Tangerine is a safe variety to plant.

\section{Valencia Orange}

\section{See illustration on page 13}

This Orange has been known by many names, Hart's Late, Tardiff, Valencia Late, etc. It came to America from Spain in different ways, but it is all one Orange. Today it is the most widely grown late Orange and the only one to be considered for its season, March to May. At this time of year, Oranges generally command a fine price, and, consequently, plantings of Valencia are very profitable In planting Valencia, a locality must be selected that is reasonably free from frost, as the fruit remains on the trees throughout the winter months. Valencia fruit is of medium size, of good color, with thin skin, and firm, deep orange flesh. It contains only a few seeds. In quality, it is delicious, and in this respect nothing more could be desired. The tree is a strong grower, and our selected strain from one of the finest Valencia orchards in California is a good bearer. We have tested out a large number of different strains of Valencia and still have many of them in fruit in our test orchard at Winter Haven, Fla., where our customers may see them. While these show little or no variation in fruit or tree characteristics, we believe the one we are propagating is the most prolific. 


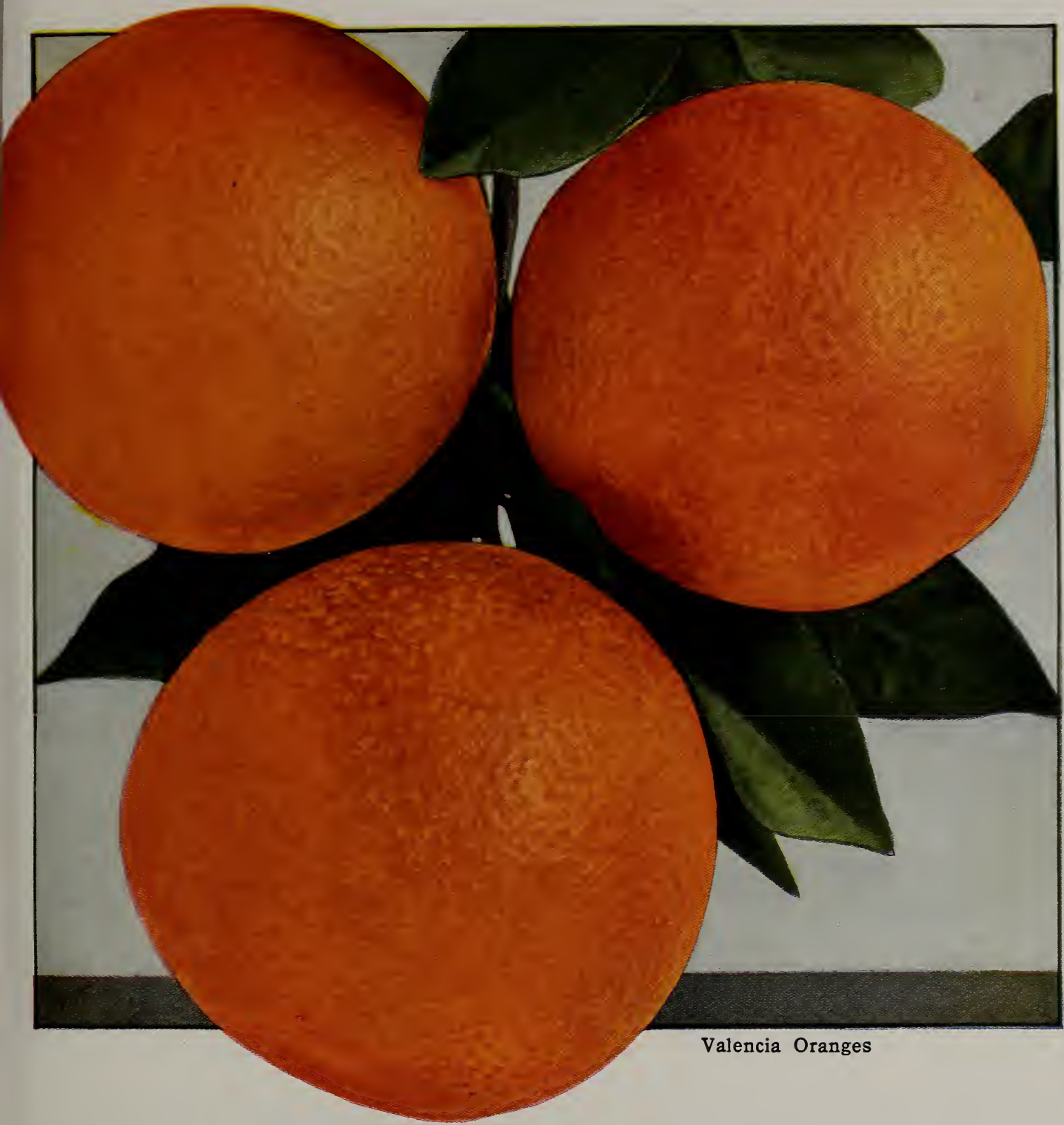

\section{Washington Navel Orange}

In many ways this is the most remarkable Orange grown today. It is the Orange which standardized the output of California citrus orchards, and perhaps it is not too much to say that this single variety has been in a large measure responsible for citrus development in that state. Florida growers are not, or should not be, interested in it, because it will not yield enough fruit to pay for planting it. Fruit can be secured from trees budded on Rough Lemon or Citrus trifoliata stocks, but even then it has no place in a commercial planting. We grow it for our trade in other countries. The fruit carries its own trade-mark - the navel marking on the blossom end of the fruit. In size, it is large, the pulp meaty, not so tender and juicy as some of the finer varieties, but still a very fine Orange. It is an excellent shipper, and its high color and seedlessness are other important points in its favor as a market fruit. It can be grown successfully on heavy soils in irrigated districts, and for such localities it is highly recommended. Introduced from Brazil, in 1870 , it was exhibited at Riverside, Calif., in I879 and shortly after that its propagation and planting were undertaken. 


\section{SOUTHERN Planting FACTS}

Citrus Fruits

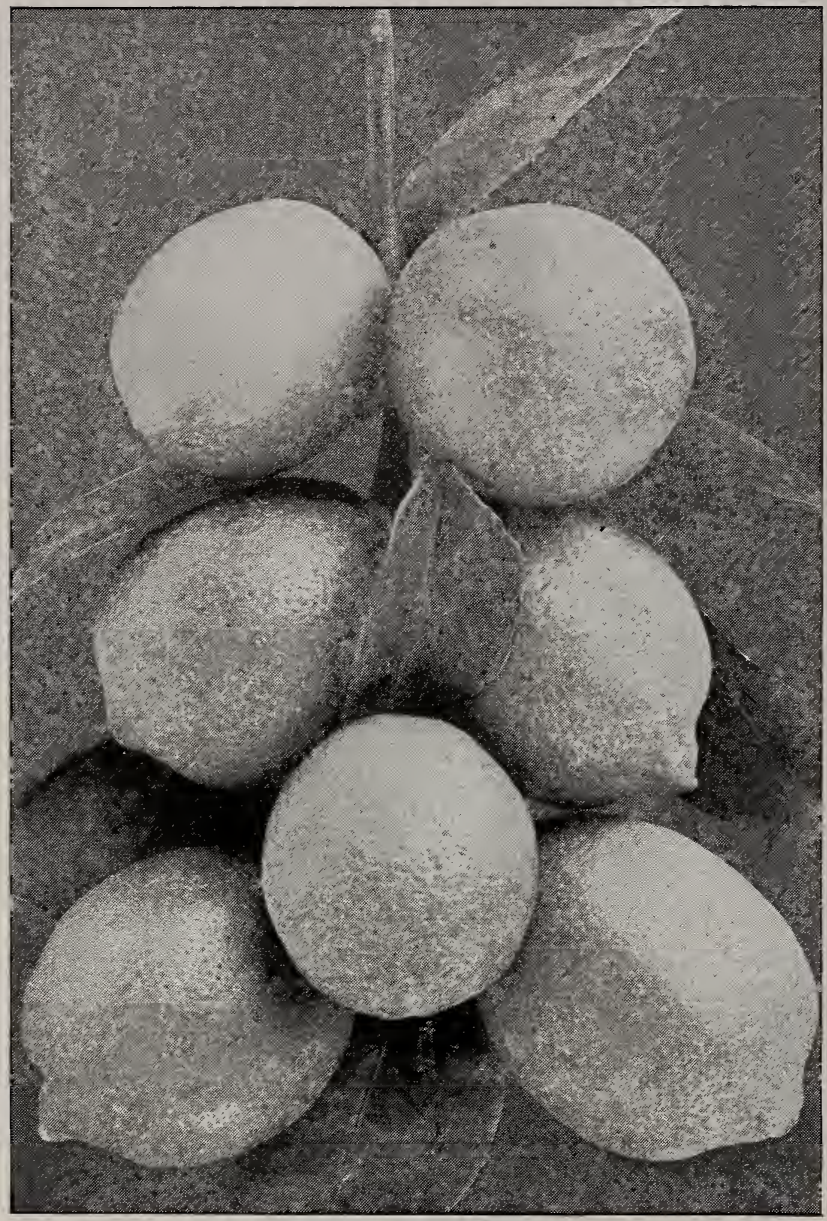

Villa Franca Lemons

\section{LEMONS}

While not so hardy as the orange and pomelo, yet Lemons can be grown over a wide range of territory. Even in north Florida we have often been able to produce more fruit than we could use. Certainly no collection of citrus fruits for home use in the citrus belt is complete without a few Lemons, and in sections most immune from cold this fruit may be grown in quantity.

A number of years ago, before the newer sections of Florida were opened up, Lemons were raised in considerable quantities. A number of causes contributed to the reduction of the plantings, until at this time Lemons are grown in small numbers only. It is now quite certain that a return to the planting of this citrus fruit will make a profitable investment under proper conditions. The growing of Lemons for use in this state alone is an industry worthy of consideration.

\section{Ponderosa Lemon}

An exceptionally large Lemon, fruits weighing from $\mathrm{I} 1 / 2$ to $2 \mathrm{I} / 2$ pounds. This fruit, while a great novelty, has at the same time a well-defined usefulness The juice from one of them will make a large pitcher of lemonade. It can also be used in all the culinary ways in which ordinary Lemons are used. It makes a very fine, thrifty, ornamental tree and bears heavy crops when quite young. Two or three of these trees should be included in every home orchard planting.

\section{Villa Franca Lemon}

In our test orchards we have grown and fruited for years all the important commercial varieties of Lemons. As a result of these tests we are convinced that Villa Franca is the Lemon for Florida. It has taken first rank in many competitive exhibits, and is the variety to plant for either local use or for market. The fruit is juicy, strongly acid, and of fine quality, almost or quite seedless. The tree is quite free from thorns, a fine grower, and produces regularly fine crops of good fruit. A few trees to provide fruit for home use or for local market are a valuable addition to a citrus planting.

\section{Gitrus Fruits and Their Culture}

\section{By H. HAROLD HUME}

This work is heartily indorsed by the leading growers of Citrus Fruits and is the standard work on the subject. The subject of Citrus Fruit growing is thoroughly covered in all its phases, from the preparation of the land and the planting of the trees to the marketing of the fruit. For the grower engaged in the production of first-class Citrus Fruit, it is an invaluable book. It contains 597 pages, well illustrated with line drawings and half-tone engravings. Price, postpaid, $\$ 2.50$. 


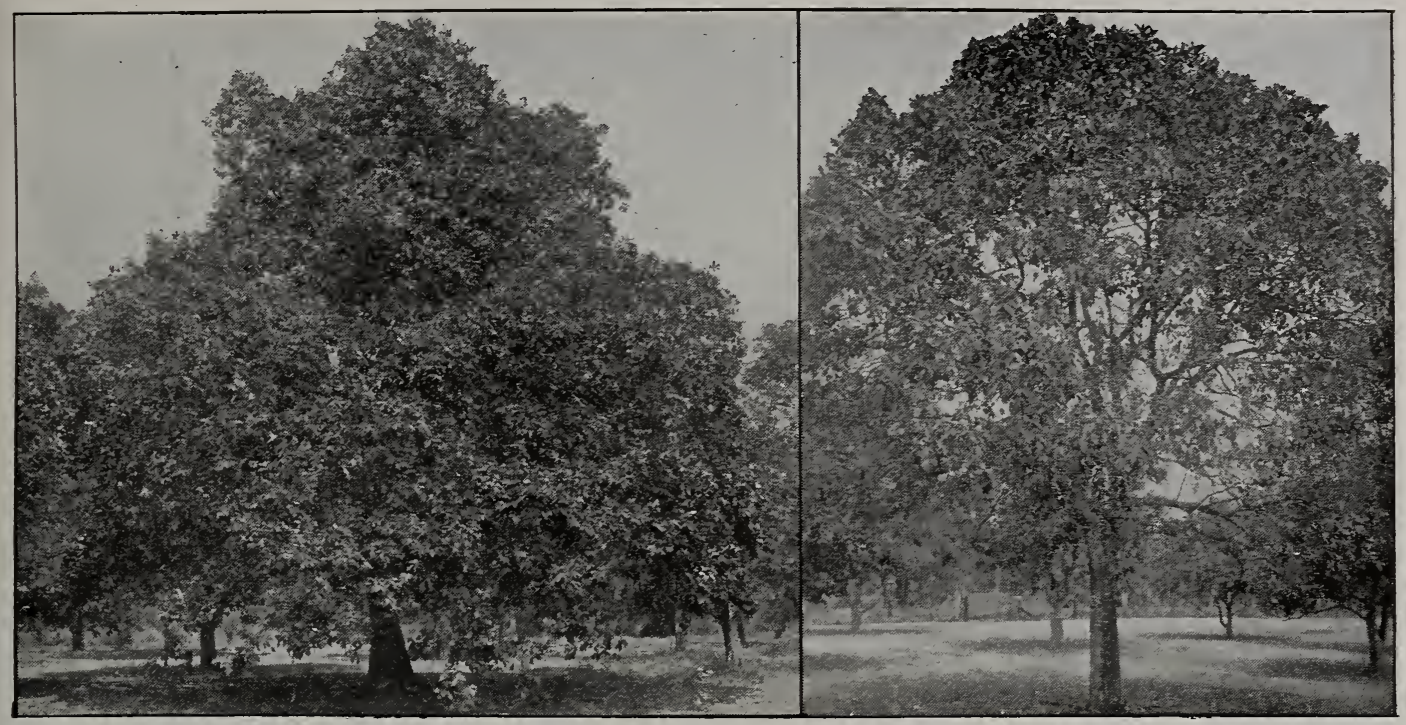

Sister Tree to Duncan

Original Duncan Tree

Though over eighty years old, these trees are still producing enormous crops of fruit

\section{GRAPEFRUIT}

The Grapefruit industry of today is a growth of not more than thirty-five years. The increase in cultivation, production, and use of Grapefruit is without a parallel in American horticulture. It is Florida's greatest single fruit contribution to the tables of the world, and it is in Florida that its culture has reached its greatest development. Its consumption has increased faster than the supply. Extensive advertising in various ways, resulting in wide distribution, has been a large factor in popularizing this comparatively new and very wholesome fruit. Prices obtained by Grapefruit growers during the past two seasons have been extremely good, and there is every indication that these will be maintained. In addition, it should be remembered that, tree for tree, a Grapefruit planting will produce twice the number of boxes of fruit that orange trees will at practically the same cost of production. For example, under the same conditions, assuming that a six-year-old orange tree will produce 2 or 3 boxes, a Grapefruit tree of the same age will yield 4 or 6 boxes. The market for Grapefruit is continually broadening, prices are good, the trees bear heavy crops, and considering the very limited area where real Grapefruit can be successfully grown, the outlook is very promising indeed.

We have tested out and are familiar with nearly all varieties. Those we list cover all requirements for general planting. While the ripening and marketing period of different commercial Grapefruits is not quite so distinctive as that of oranges, still the varieties we grow cover a wide marketing period. The variety or varieties selected for planting is largely a matter of personal preference, but we know that all varieties we offer are good and are desirable for planting.

\section{Duncan}

We consider Duncan the finest Grapefruit grown. During all the years we have been in the citrus business (and during this time we have grown, observed, and tested a host of varieties), we have never found a Grapefruit which is quite the equal of Duncan in all-round desirability. It has everything a Grapefruit should have, and is lacking in no particular. Its size is exactly what the markets want and pay best prices for-54's to 70's. Its shape is round, slightly oblate, and it packs well. Color a clear light yellow, with oil-cells showing through the smooth skin. The juice content is particularly heavy and possesses more than any other Grapefruit the true sweet-bitter-acid-grapefruit flavor. The season of this fine Grapefruit is an extended one. It is ripe enough in color and quality to ship in early December, and it can be held on the tree without deterioration until late in May. We have been propagating Duncan for more than a quarter of a century. Our first budwood was secured from the original tree, which is illustrated on this page. About a hundred and ten years ago, a Spanish nobleman, Don Phillippi, settled near Green Springs, in what is now Pinellas County. There he planted Grapefruit seeds and grew a citrus grove. This is the oldest Grapefruit planting of which we have a record, and doubtless many of the old seedling plantings throughout Florida owe their existence to this Spaniard's enterprise. One of his trees, still living, produced fine fruit, and seeds of it were supplied 


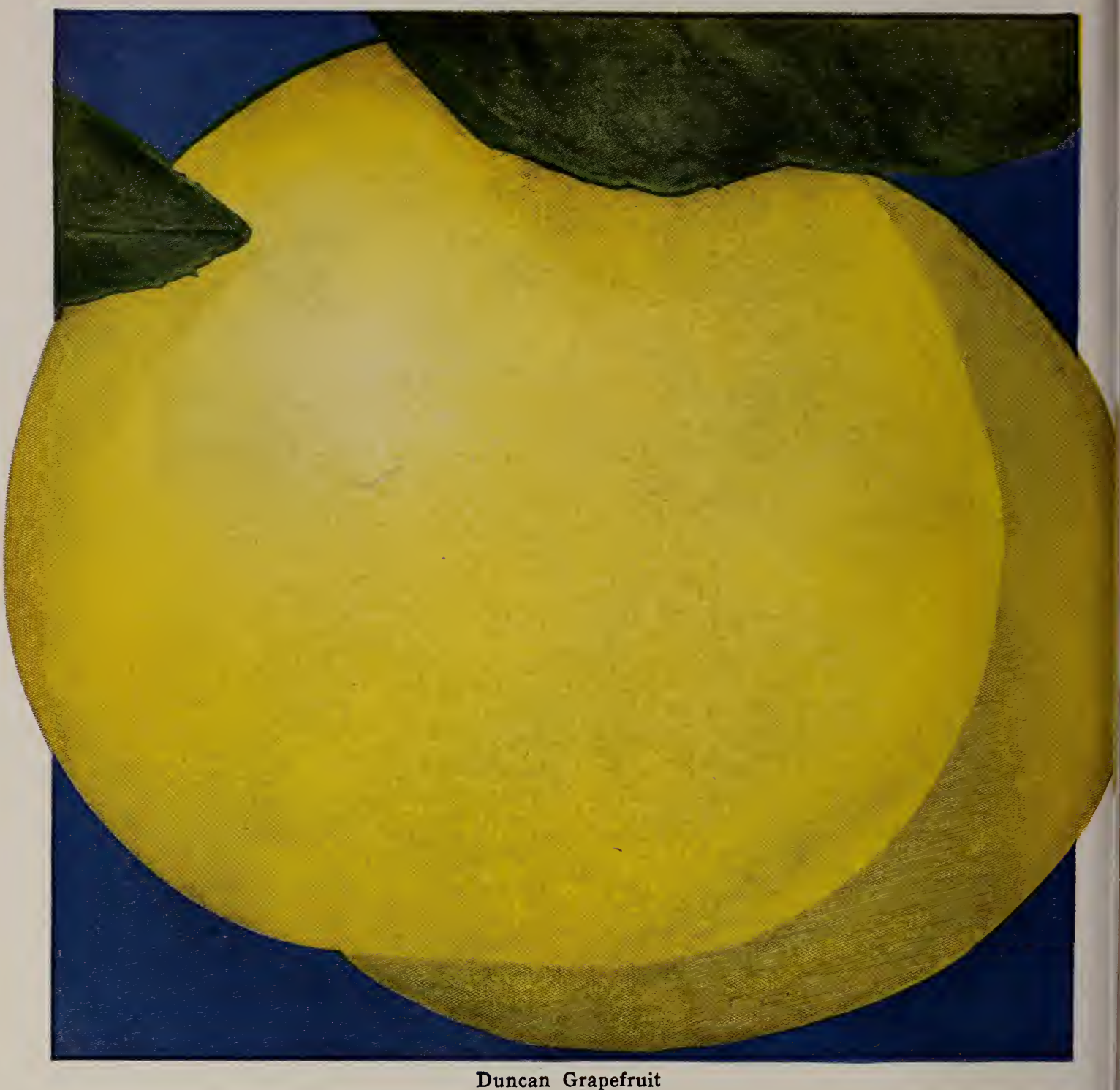

to his neighbors. Duncan is a seedling of this original tree and was first brought to notice by Mr. A. L. Duncan, of Dunedin, Fla. Mr. Duncan discovered the tree quite by accident. The fruit was served him at tea one Sunday evening by Mrs. Snedicor, the owner of the grove in which the original Duncan tree stood. It was of such exquisite quality and so superior in every way to any he had known throughout his years of experience as a grower that he became deeply interested in it. He exhibited specimens at the horticultural society meeting where the fruit attracted much attention. The president of our company, Mr. G. L. Taber, secured budwood from the original tree through Mr. Duncan, grew trees of it, and first offered it for sale in the catalogue issued in September of 1895. Mr. A. L. Duncan said of it, "I do not know how either tree or fruit could be improved," and today it stands in a class by itself, even as it did then. We have been propagating Duncan ever since. The original Duncan tree at Green Springs, Fla., has weathered the storms, cold spells, and neglect of more than eighty years and is still bearing good crops. Through all the cold periods which we have experienced during the past quarter of a century, both in north and south Florida, we have observed that Duncan invariably has suffered less than any other variety. It is unquestionably the hardiest of all the Grapefruit. 


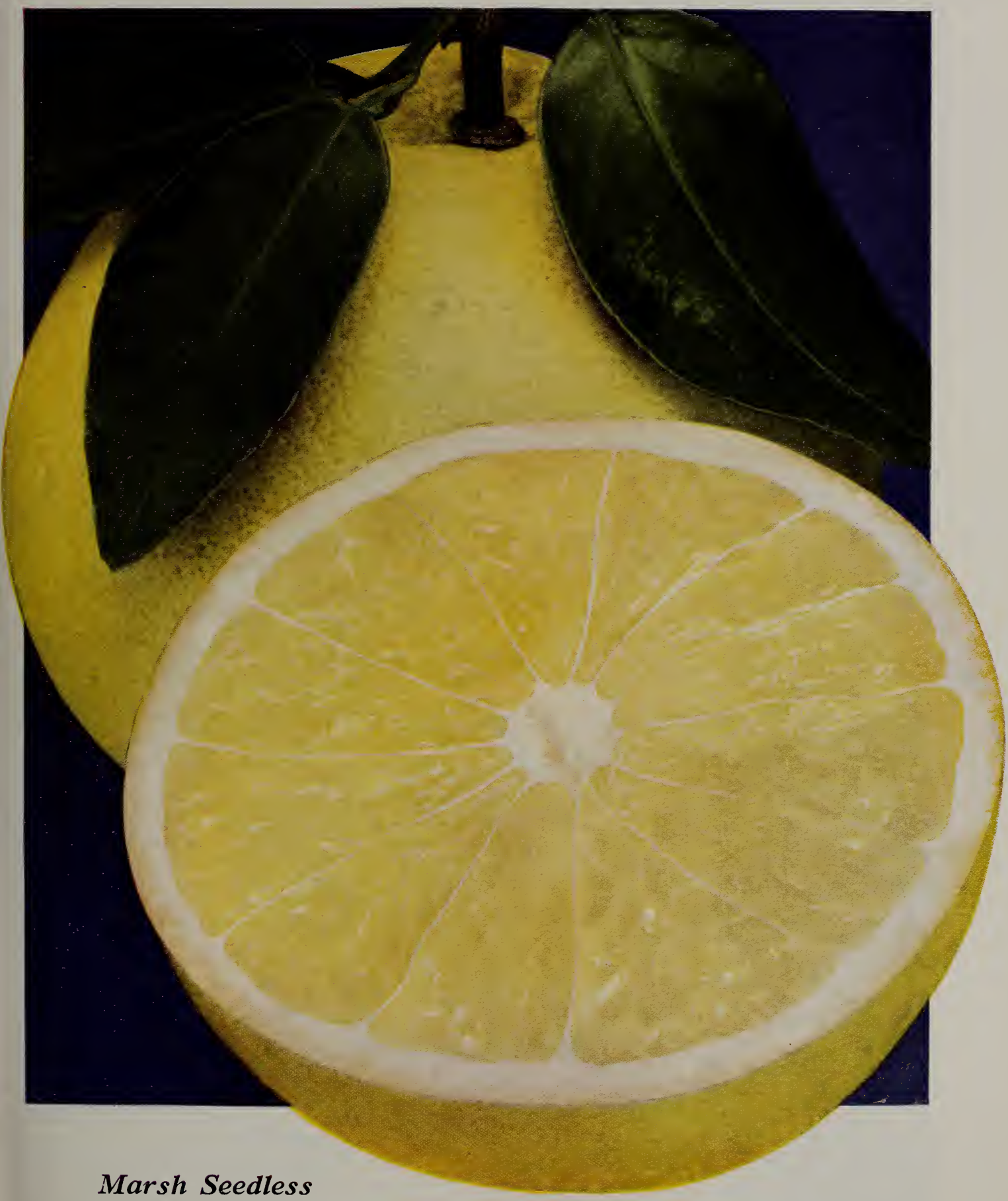

This fine variety originated at Lakeland, Fla., and was first brought to notice and grown by $\mathrm{Mr}$ C. M. Marsh, about I 895. Its most marked characteristic is its practically seedless fruit. Its marketing season begins in January, and, because it is so nearly seedless, the fruit can be held on the trees later 


\section{SOUTHERN PLANTING FACTS}

Citrus Fruits

\section{Marsh Seedless Grapefruit, continued}

than all other varieties except McCarty, which is equally late. The fruit is very handsome in appearance, with smooth yellow skin. The quality is fine, a great favorite in the markets, and always commands good prices. It is becoming known as a distinct variety, and sells, not simply as Grapefruit, but under its own name. Like all other varieties of Grapefruit which we grow and recommend for commercial planting, Marsh Seedless fruits run in the sizes most desired by the fruit trade.

The tree makes a low, dense, spreading head, often measuring more across the spread of the branches than it does in height. It bears heavy, regular crops. In every well-balanced planting, Marsh Seedless should be given a liberal place.

\section{McCarty Grapefruit}

Many years ago the McCarty Grapefruit, an Indian River variety named after the late Mr. C. T. McCarty, attracted our attention. After keeping it under observation for several years, we decided to propagate it. It possesses in a marked degree the distinctive habit of producing its fruits singly instead of in bunches or clusters. This feature, coupled with its late ripening period and its very high quality have so impressed us with its merits that we have come to regard McCarty as one of the finest Grapefruits grown in Florida today. Because

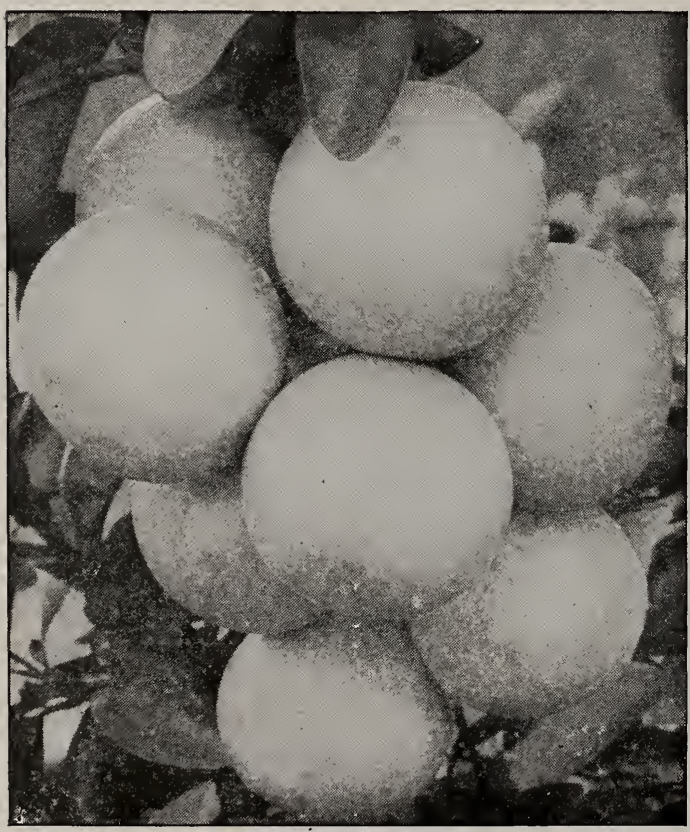

Triumph Grapefruit

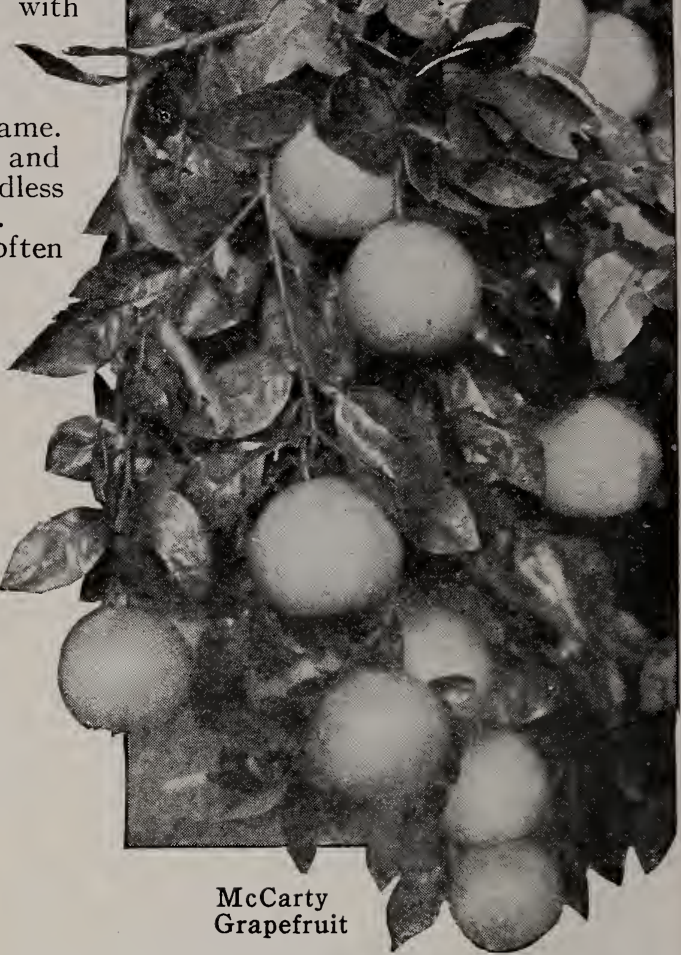

it does not grow in clusters, the fruit is very uniform in size and shape, and very free from those blemishes caused by clustering, such as extensive scale injury and misshapen fruits. We believe this variety is not surpassed by any other as a regular, uniform bearer. The fruit is of best market size, light, waxy yellow in color, with skin of beautiful texture. It is distinctly a fancy fruit; has a perfect Grapefruit flavor and the flesh is melting, free from fiber and rag when properly grown.

\section{Triumph Grapefruit}

For an early Grapefruit, particularly for home use or local market, there is no better variety. It is in good eating condition in November, and has a season of about eight weeks, depending upon the stock upon which it is propagated and the section in which it is grown. It is a very prolific sort, and the fruit, though smaller in size than our other varieties, runs very uniform. It is heavy, juicy, well flavored, and smooth skinned. It is sweeter than Grapefruit ordinarily is and of very fine quality. The tree is more susceptible to cold injury than our other varieties. 


\section{GLEN SAINT MARY NURSERIES}

\section{Citrus Fruits}

\section{Silver Cluster Grapefruit}

In some parts of southern Florida, the Silver Cluster Grapefruit is one of the most popular varieties. Some of the finest and most profitable Grapefruit groves are planted with this sort. The fruit is light yellow in color, of standard size, juice almost colorless, well flavored with a true Grapefruit mixture of flavors.

Silver Cluster Grapefruit can be shipped in December, but keeps well on the tree throughout the shipping season.

\section{Walters Grapefruit}

It is believed by some that this variety and Silver Cluster are the same, but this is not true. The origins of the two are entirely different, and in character of fruit, seeds, etc., they show distinct varietal characteristics. Walters is a splendid Grapefruit. It is ready for market, though not at its best, late in Norember, and keeps well on the trees up until about May. In size the fruit runs in favorite market sizes, 46 's to 64 's. It is a heavy

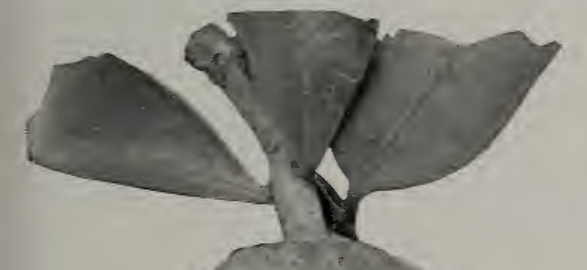

bearer of good quality fruit and we recommend it as a good variety for fairly early market.

\section{The Tahiti Lime}

Of all the acid fruits which may be grown in Florida, the Tahiti Lime is one of the most satisfactory for home use as well as for commercial planting. It is not quite so hardy as the lemon and its culture should be confined to localities where there is little or no danger of injury from cold. It grows as a dense-foliaged, round-topped tree, I2 to I 5 feet in height. It is a very vigorous grower and remarkably free from insect and fungous pests.

The fruit of Tahiti is of the finest quality for making ade. It is best suited for use when full size but while the skin is still green. In size and shape it resembles a small lemon, but it is a much smoother and nicer fruit. It is seedless, has a splendid Lime flavor, and is so much superior to other varieties of Limes that it is the only one we now propagate. Our experience has shown that the Tahiti Lime is a complete success on Rough Lemon stock. On this stock it makes a splendid growth and is very prolific. Matured fruit, partly grown fruit, and blossoms are found on the trees at nearly all seasons of the year, but the heaviest bearing season is in summer when the fruit is in greatest demand. 


\section{SOUTHERN PLANTING FACTS}

Citrus Fruits

\section{KUMQUATS}

The Kumquat is the smallest of the citrus fruits in general cultivation in this country. Usually the plants are called bushes, for they do not make trees. The plant grows to a height of Io to I2 feet, with a spread of branches about equal to its height. The bright, dark green leaves and deep golden

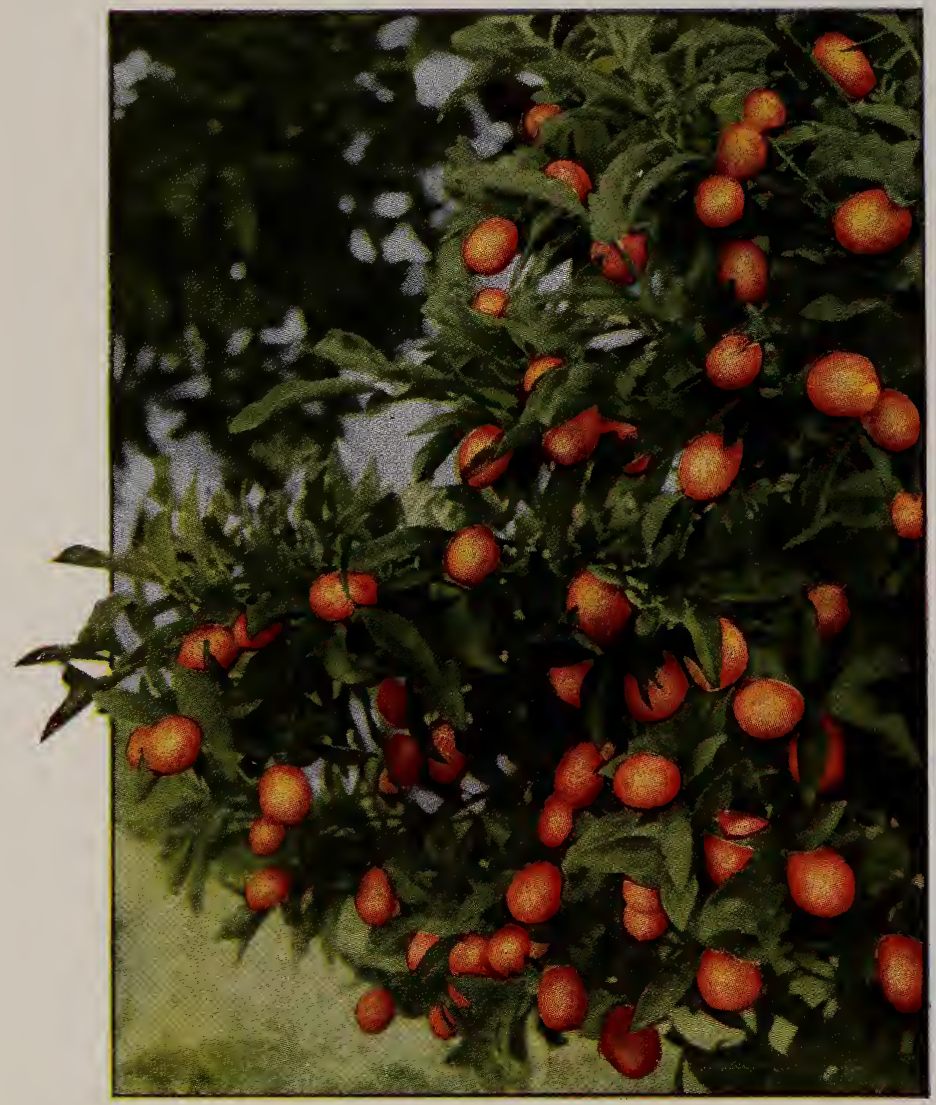

yellow fruits make a very pleasing combination of color. The flowers are small, sweet-scented, and appear in June on the shoots produced earlier in the same season. The fruit ripens during the fall and winter, beginning with the month of November. As an ornamental alone, it is not surpassed by any other evergreen shrub with which we are acquainted.

In point of hardiness, the Kumquat ranks with the Satsuma orange. It will withstand temperatures of 15 degrees Fahr. and even lower.

We are the largest growers and shippers of this fruit in the country, having marketed from four to six hundred bushels of fruit annually for several years past. The crop has netted from $\$ 2.50$ to $\$ 3.25$ per bushel, sometimes selling as high as $\$ 6$ to $\$$ IO per bushel. We have found it a profitable fruit to grow, as the trees yield well and can be planted close together. When gathering the crop we always cut the fruit from the trees with twigs and leaves attached, and pack a goodly proportion of leaves with the fruit. They are packed in quart baskets and shipped in strawberry crates. The fruit always sells better with foliage attached. This is an advantage, as the leaves help to fill up the baskets, and make a larger bulk than if the fruit alone were packed. The fruit is largely used for table decorations, and is in largest demand for Thanksgiving and Christmas holiday trade. Very appetizing jelly and marmalade may be made from the fruit, and it can also be crystallized. For commercial planting, or for use as an ornamental for home use only, Kumquats are well worth planting.

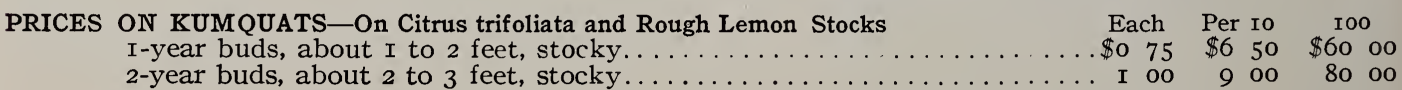

Marumi. Fruit round, about I inch in diameter; bright golden yellow. Rind sweet, with a pleasant flavor and pulp and juice sprightly; quality very fine. Tree forms a beautiful, well-rounded, symmetrical head.

Nagami. Fruit oblong, about $\mathrm{I} / 2$ to 2 inches in length and $\mathrm{I}$ inch in diameter; fruit golden yellow; rind sweet; pulp and juice sprightly, of fine flavor. Tree forms a nice head a little more open than Marumi.

Neiwa. Fruit round, slightly larger than Marumi; pulp sweet when fully ripe. Of recent introduction and very desirable. Best of all Kumquats to eat out of hand. Grown on Rough Lemon stock only. 


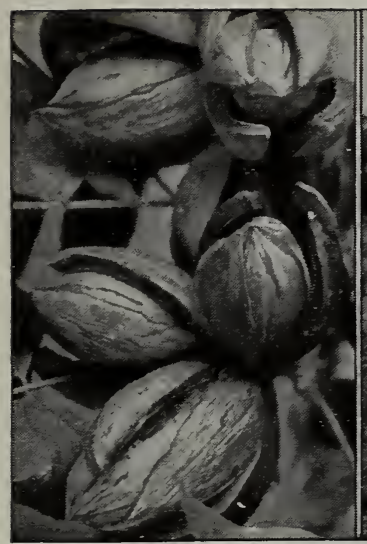

Teche Pecans

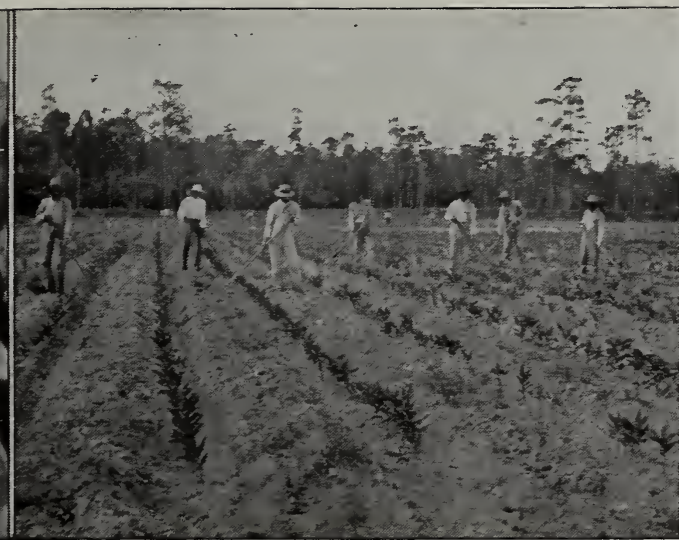

Cultivating Pecan Nursery

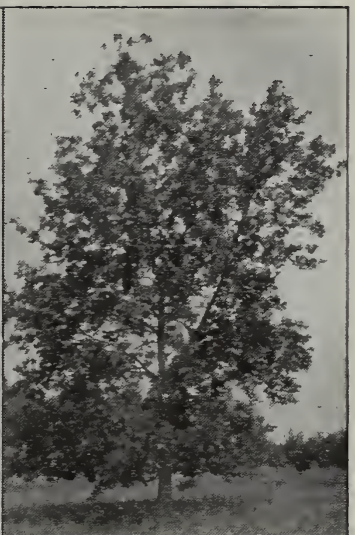

Frotscher Pecan Tree

\section{PECANS}

In recent years the Pecan has become a very important nut, particularly in the Southern States, ard it may be said that there is no other fruit or nut tree which fits so well into the general farming of this region as the Pecan. Cotton, corn, cowpeas and other farm crops can be grown to advantage among the trees when they are young, and even until the trees have begun to bear well. In short, the land may be farmed almost as though the trees had not been planted on it, yet the trees, under this management will grow and do well. The region in which the Pecan may be grown, with a proper selection of varieties, extends from Virginia to Florida, thence west into Texas and Oklahoma. It is destined to become the most important horticultural tree in this whole region, and the Pecan orchards of the South will rival the apple orchards of the North and Northwest. The Pecan, under proper conditions, will continue to bear fruit long after other fruit trees planted at the same time have ceased to grow; in fact, a Pecan orchard is equal to many peach orchards-for instance, in length of life and fruitfulness. As shade trees they make handsome specimens, and they are well adapted for street, road and yard planting.

\section{Pecan Soils}

While it is a fact that the Pecan tree will succeed on a wide range of soils, it is wise, since it is a valuable, longlived tree, to choose good land for the Pecan planting. This soil should not be low and wet; it should be,well drained, yet it should contain a goodly supply of moisture. Sandy loams underlaid with clay, light clay lands and alluvial lands are suitable. The land should contain humus in goodly amounts for best results. Before planting, the land should be thoroughly cleared of stumps and roots; if it is good farm land, and in good farming condition, it will be ready for planting at once, but new lands, or those deficient in humus or vegetable matter, should be well broken, and

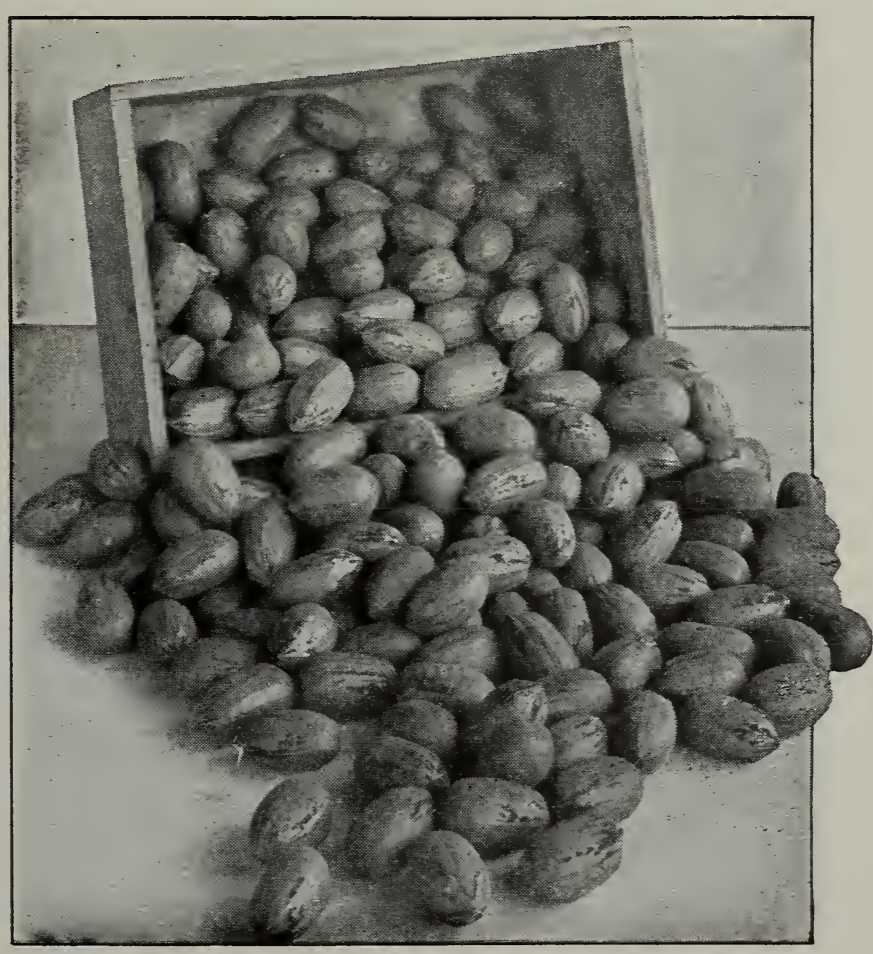




\section{SOUTHERN PLANTING FACTS}

\section{Nut Trees}

planted in cowpeas or velvet beans for at least one season before planting. In autumn, after the vines are dead and dry, they should be plowed back into the land, and the soil well harrowed, to put it in best condition. This will add the needed humus to the soil.

\section{Cultivation}

The best cultivation for a Pecan tree does not differ materially from that given other kinds of fruit trees. The orchard should be plowed during winter. Cultivation should begin early in spring before growth starts and should continue at intervals of a week or ten days until about the first of July, when cultivation may be discontinued. If the land is planted in truck or farm-crops, there should be a strip of 5 or 6 feet on each side of the tree rows left unplanted. This strip should be cultivated regularly, to conserve moisture and keep the trees in good growing condition. In six to eight years after planting, the trees will begin to bear light crops, and by ten years they should be yielding fairly well. After this, it is doubtful whether it is good practice to continue cropping the land, both because the trees need the land and because the shade cast by them will interfere with the crops. Indeed, cropping may have to cease earlier, particularly if the trees are closely planted. Crops of cowpeas, beggarweed or other legumes should be grown from time to time and turned into the land. A good fertilizer for young trees is one containing about 4 per cent ammonia, 7 per cent phosphoric acid and 3 per cent potash. For bearing trees increase the potash to about 5 per cent. Stable manure and wood-ashes can also be used to advantage.

\section{Marketing Pecans}

The Pecan crop should be harvested as soon as a majority of the burrs are open, showing the nuts. The trees should be stripped of their crop at one picking. After gathering, remove the husks and spread out in shallow trays in the sun to dry. They should be removed to a well-ventilated storage room at night. It will take several days of drying, out-of-doors and in the house, before they are ready to pack. The variety should form the basis of the grade. If irregular in size, they should be screened and divided into different sizes.

At the present time practically all the Pecans of improved varieties are sold to a private trade. Hardly any of them as yet find their way into the general market, as the supply is so far short of the demand. For quantity shipments, barrels are best; for smaller packages, neat wooden or corrugated-paper boxes are most satisfactory.

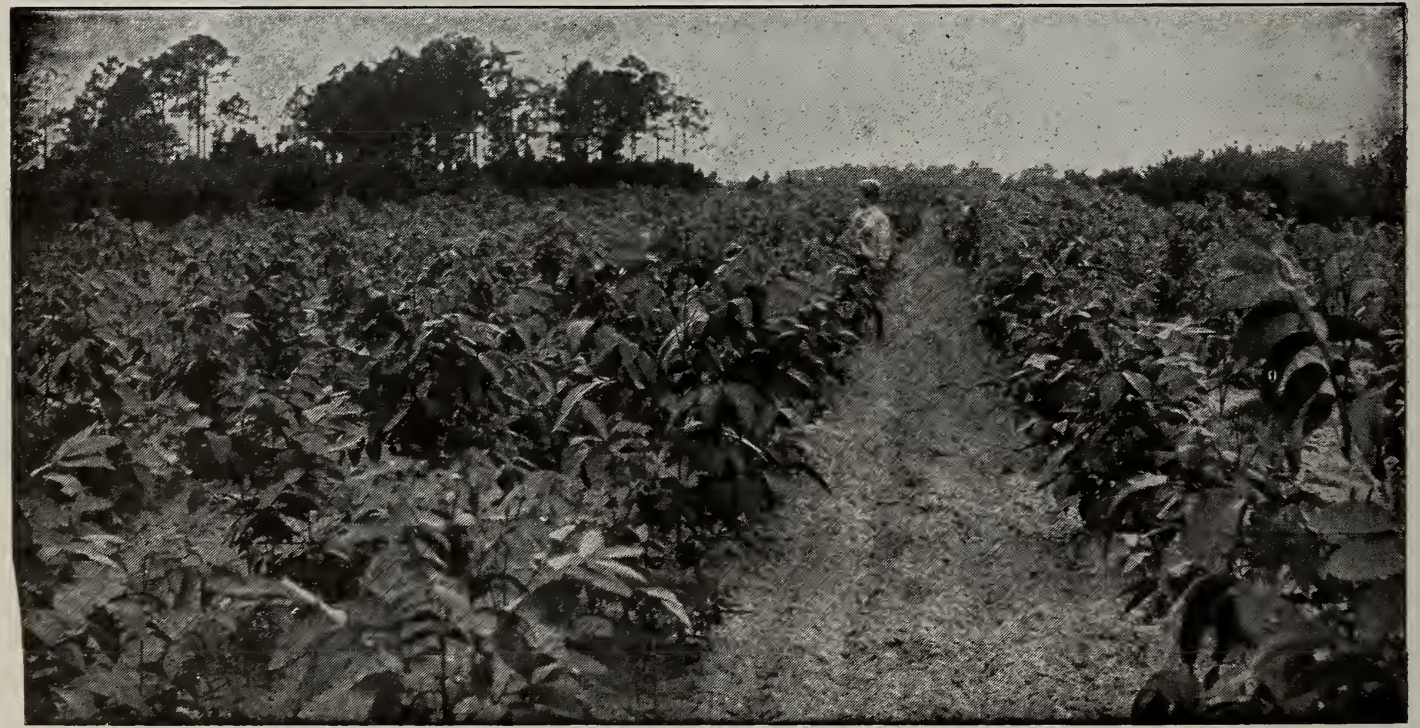

A Block of Pecan Nursery Stock 


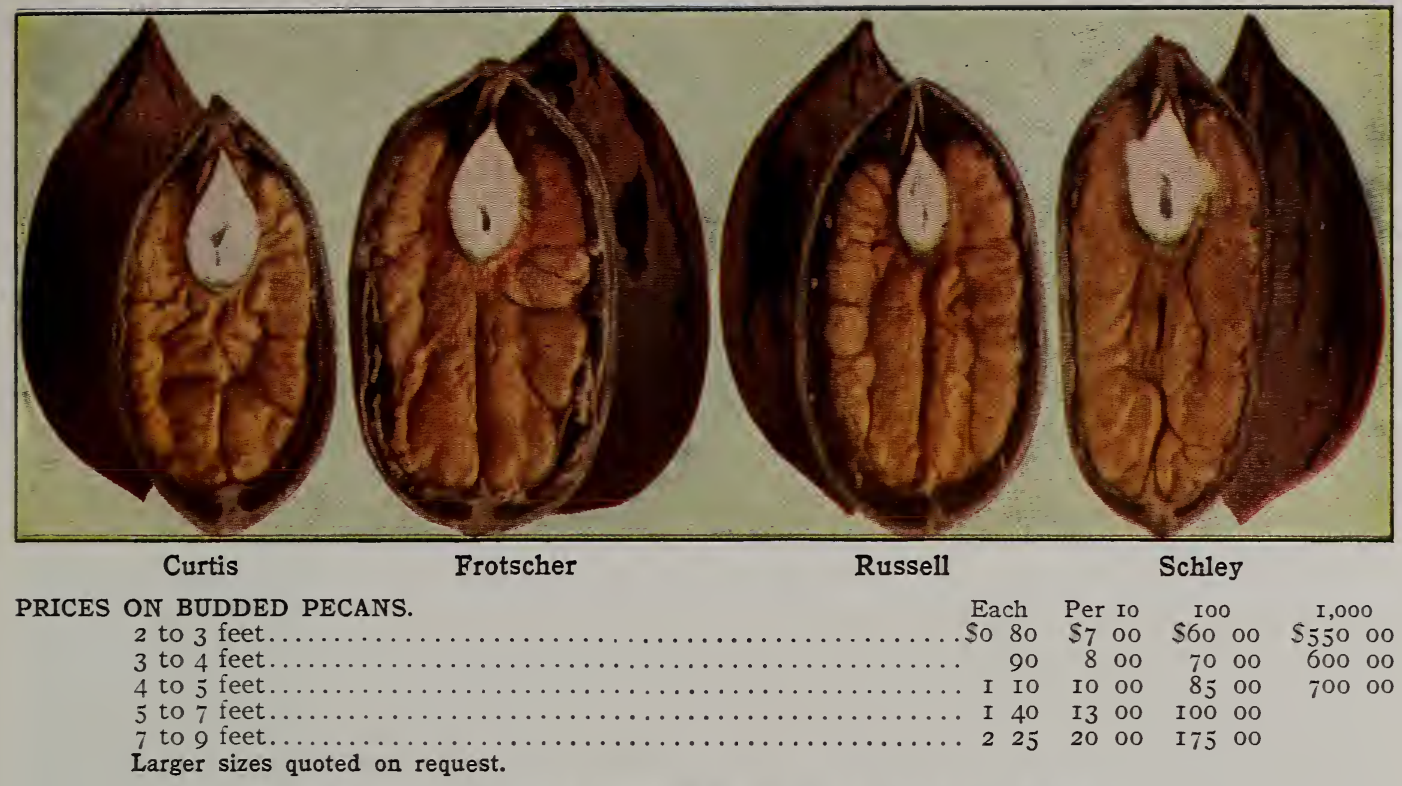

\section{VARIETIES OF PECANS DESCRIBED}

Curtis. A medium-sized Pecan, with bright, ciean shell, marked with a few purplish specks; ovate, rounded at base, pointed at the apex; shell very thin; cracking quality excellent; kernel yellow, plump, full; rich, nutty flavor.

Frotscher. A large, oblong nut, I $3 / 4$ to $I 7 / 8$ inches in length; bright yellowish brown in color with a few purplish black markings; shell very thin, cracking easily. Kernel large, easily removed, full, of good quality. Tree a vigorous grower, of spreading habit with scaly bark; bears heavy crops and can always be depended upon.

Moneymaker. Size medium, I $1 / 4$ by I inch, rounded, oblong; light yellowish brown shell of medium thickness, cracking easily: kernel full, plump, rich. A heavy bearer of splendid nuts.
Russell. A medium- or large-sized nut, I $1 / 2$ to $\mathrm{I} 3 / 4$ inches long, oval and pointed; grayish brown, with numerous small, purplish black markings. Shell thin, of excellent cracking quality; kernel plump and of good quality. A good grower and bears large and regular crops.

Schley. Size medium to large, I $1 / 2$ to $I 7 / 8$ inches long; oblong, somewhat flattened; light reddish brown; shell thin, separating easily from the kernel; kernel full, plump, bright in color; flavor rich, nutty; quality best.

Stuart. Nuts large to very large, I $1 / 4$ to 2 inches long; oblong; brownish shell; strongly marked with dark color. Shell of medium thickness and of very good cracking quality. Kernel full, plump, bright-colored. Heavy bearer.

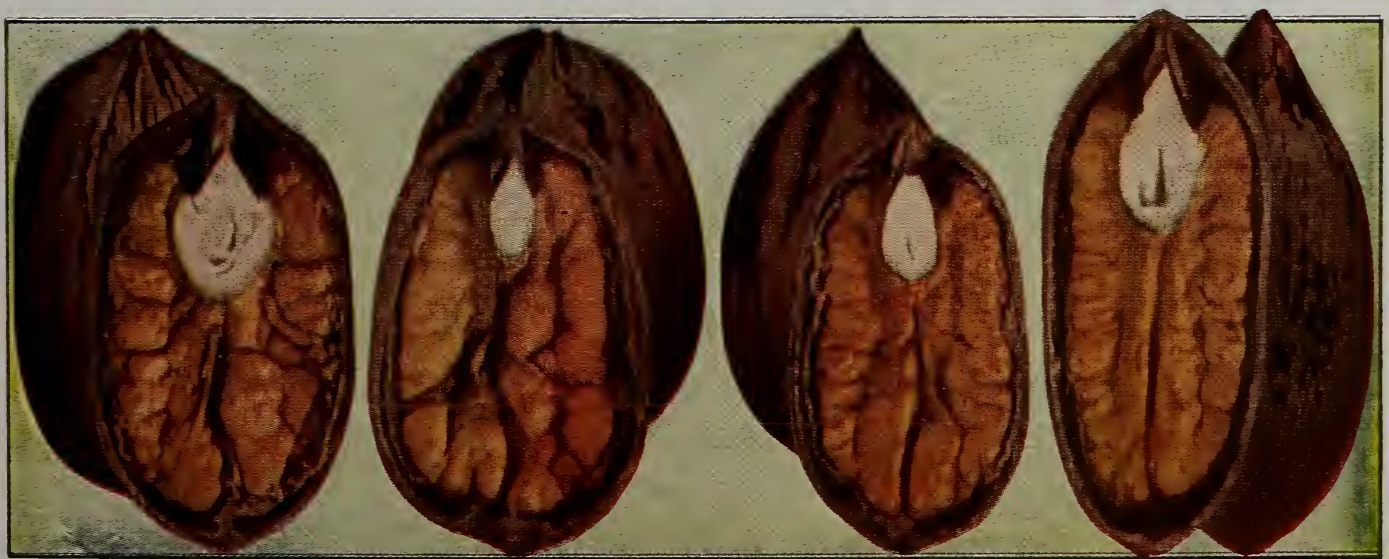

Stuart

Success

Teche

Van Deman 
Nut Trees

Success. Size large, oblong, tapering to the apex. Color reddish brown, purplish markings, shell thin, cracking quality good, partitions thin; kernel large, full, plump, yellow; flavor sweet; quality very good. The tree is a good grower. A fine variety.

Teche. Size medium to large, oblong; grayish brown in color with a few dark streaks; base and apex rounded; shell medium; cracking quality good; kernel full, plump; quality good. One of the best.

Van Deman. Large to very large, from $\mathrm{I} 7 / 8$ to $2 \mathrm{I} / 8$ inches long, rather slender, pointed at both ends. Color reddish brown, with purplish brown markings. Shell of medium thickness; cracking quality excellent. Kernel plump, bright, sweet.

\section{The Pecan and Its Culture}

\section{BY H. HAROLD HUME}

Pecans are rapidly becoming one of the most important orchard trees in the South. In fact, for general planting they are entitled to first place because of their peculiar adaptability to many conditions and locations. The merits of this valuable nut are being recognized as never before, and the crop has gained a firm place in the markets of the country. To supply reliable information on Pecan-growing, this up-to-date work, touching every cultural detail, has been prepared after many years' careful study of the industry. The book is thoroughly practical and contains the information needed by every grower of Pecans. Second edition, 195 pages cloth-bound; price $\$ \mathrm{I} \cdot 5 \mathrm{O}$, postpaid.

\section{WALNUTS}

PRICES ON JAPAN WALNUTS FROM SEED.

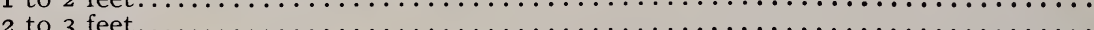

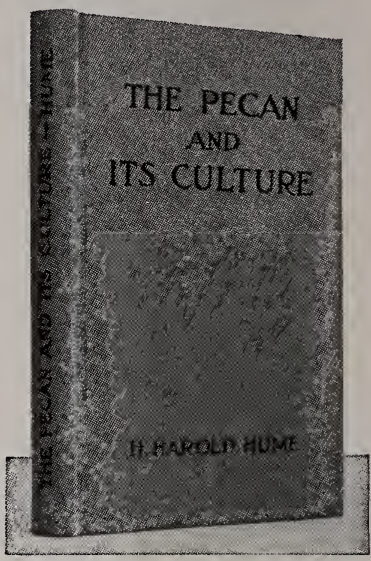

Japan Walnut. In the develop-

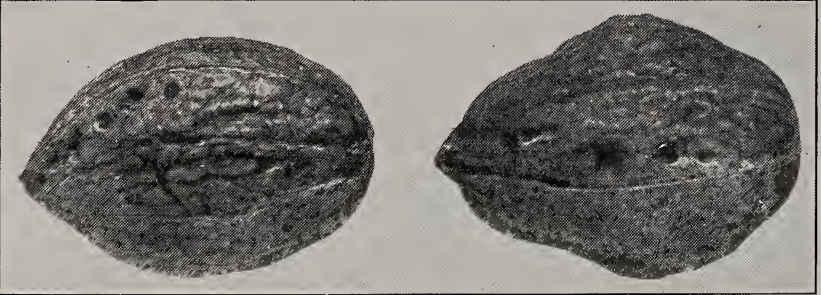

Japan Walnuts
Each Per ro \$o $40 \quad \$ 350$

$50 \quad 450$ ment of the nut industry, the Japan Walnut is well worthy of a place in every planting, and no home orchard should be without a few trees. They should be planted on well-drained land-a sandy or clay loam with a clay foundation is well adapted. The tree is a vigorous grower, and comes into bearing early. In habit of growth it is low and spreading, reaching a height of 15 or 20 feet, with a spread of branch of about the same distance. It makes a beautiful lawn or shade tree. The leaves are large and handsome. The nuts are borne in clusters of fifteen to twenty. They have rather thick shells, with sweet, plump kernels of very fine quality. This Walnut may be grown on well-drained lands over a wide range of territory. It may be grown as far north as New York state.

\section{ALMONDS}

PRICES ON ALMONDS.-On Peach stock.

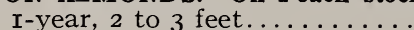
Each Per io

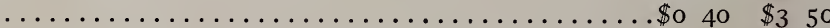

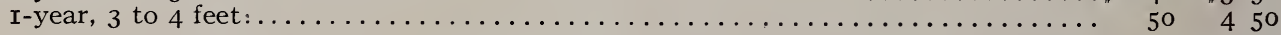

Not certain bearers in the South, and are not recommended except for garden planting. We offer two of the finest varieties, Sultana and Princess, the soft-shelled Almonds of commerce. The Almond is adapted to dry, well-drained soils. It cannot be grown successfully on soils in which there is an excess of moisture. 


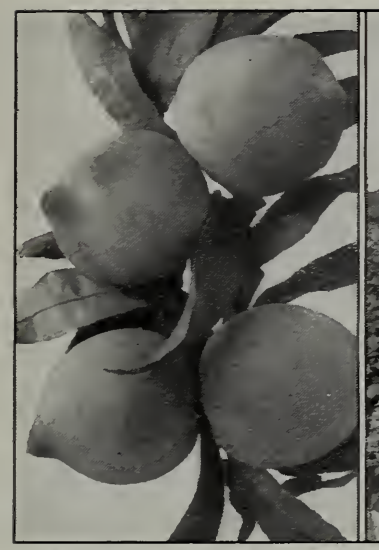

Florida Gem Peaches

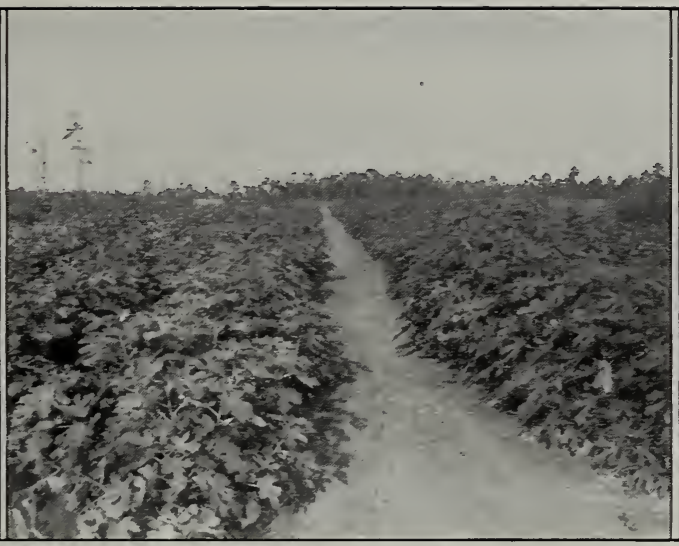

Fig Trees in Nursery

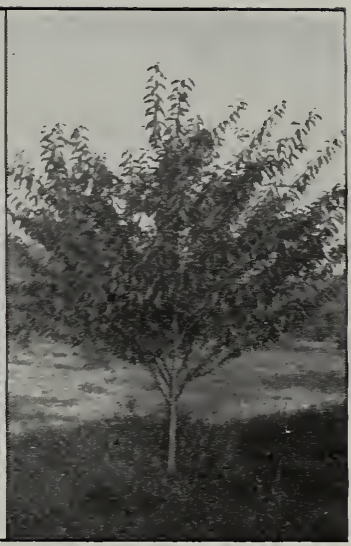

Terrell Plum Tree

\section{Deciduous Fruits}

In the lower South there are a number of deciduous fruits of decided merit which may be planted to advantage either in commercial orchards, or for home use. The most important of these are Peaches, Plums, Persimmons, Figs, Pears and Grapes. To a less degree, Pomegranates, Mulberries, Quinces and Apples are well worth while, in many sections. It may seem strange to include the Pear, for instance, but the Pear, since the introduction of blight-resistant varieties, is coming back again. We have a large number of these under test.

There are several distinct features in favor of deciduous fruits. Planting can be easily established at low cost, and results are quickly secured. When intelligently handled, they give very satisfactory results.

\section{PEACHES}

For thirty years we have been studying Peaches. During this period we have originated and introduced a large number of different kinds. We have throughout this period been growing nursery trees. Our land is particularly adapted to the growing of fine Peach stock, and we are able to offer our customers the best trees that can be produced. They are well-grown, true to name,-in short, "Quality trees" of the very best strains.

Varieties should be carefully selected, to have them adapted to the section where they are to be planted. This done, good trees planted on new land with good drainage, and carefully cultivated, will bring quick returns, and are among the most satisfactory fruits that can be grown.

The types of Peaches are as follows: Persian, commonly planted in the North. Northern Chinese, which includes Elberta and related varieties, generally planted in the cotton-belt; well adapted to western Florida. Spanish, native varieties that have originated in Florida and on the Gulf Coast, adapted to the latitude of northern Florida. Honey, comprising the Honey and its seedlings, adapted to northern Florida, southern Georgia and westward around the Gulf. Peen-to, comprising the original Peen-to and the varieties originated from it; well adapted to Florida, tropical and subtropical regions. Jewel is the most important commercial variety in the group. Oriental Bloods, Red Ceylon, adapted to the same range as Peen-to, and Japan Dwarf Blood to the same territory as the Honey Peach.

PRICES ON PEACHES-On Native Peach Stock.

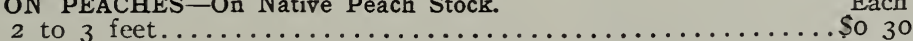

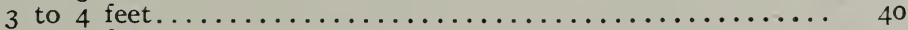

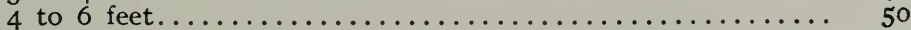

\begin{tabular}{|c|c|c|}
\hline & I00 & $I, 000$ \\
\hline 50 & $\$ 2000$ & \$I5O OC \\
\hline & 3500 & 300 oc \\
\hline
\end{tabular}

\section{LIST TO AID SELECTION}

In assigning varieties to districts of wide area, there will be local exceptions, but the following lists are based on many years of extensive planting, experimenting, research and observation.

SUCCESSION OF RIPENING.-The terms "very early," "early," "midseason," and "late,", in the following list (as indicated to the right of each variety by the abbreviations "VE," "E," "M," "L") indicate the general comparative ripening time of the variety. 


\section{Deciduous Fruits}

EXPLANATION OF LIST.-The varieties best adapted and most valuable for market in a particular section are indicated by two asterisks $(* *)$; varieties next in order of merit by one asterisk (*).

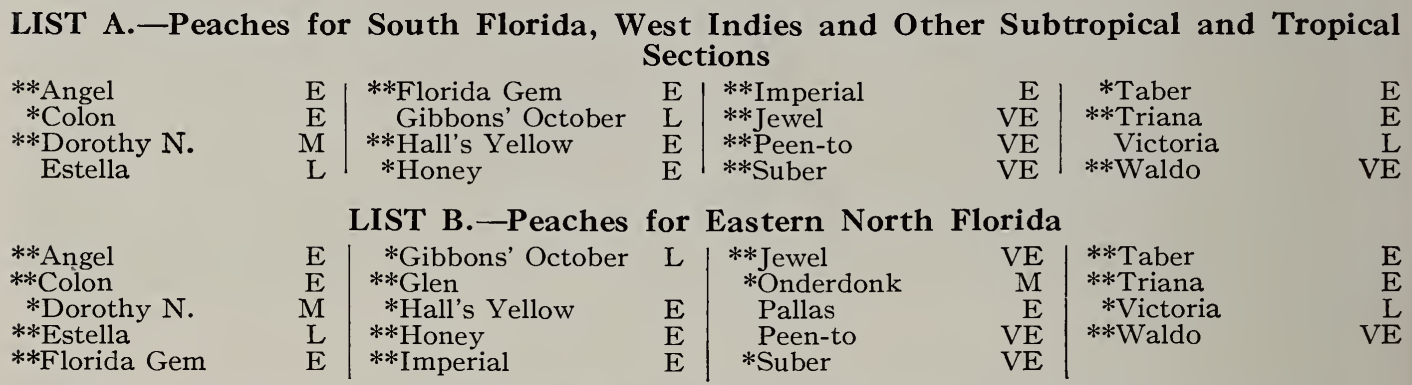

LIST C.-Peaches for West Florida and Lower Georgia, Alabama and Mississippi

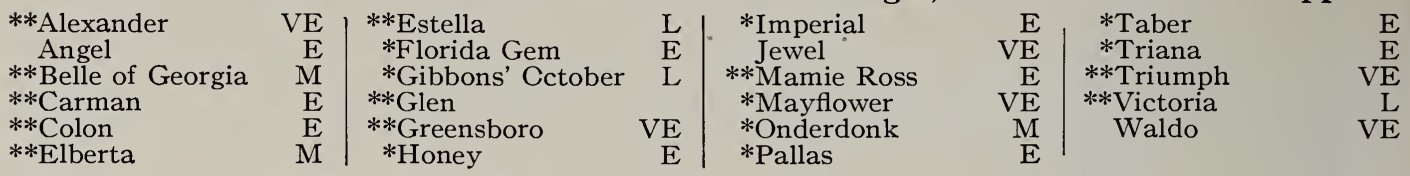

**Alexander
*Angel
*Belle of Georgia
**Carman
**Colon
**Elberta

\section{LIST D.-Peaches for Coastwise Texas and Louisiana}

\begin{tabular}{c|lc|l}
$\mathrm{VE}$ & $* *$ Estella & $\mathrm{L}$ & *Imperial \\
$\mathrm{E}$ & $* *$ I lorida Gem & $\mathrm{E}$ & *Jewel \\
$\mathrm{M}$ & $*$ Gibbons' October & $\mathrm{L}$ & $* *$ Mamie Ross \\
$\mathrm{E}$ & $* *$ Greensboro & $\mathrm{VE}$ & $* *$ Onderdonk \\
$\mathrm{E}$ & $*$ Honey & $\mathrm{E}$ & $* *$ Pallas \\
$\mathrm{M}$ & &
\end{tabular}

\begin{tabular}{|c|c|}
\hline $\mathrm{E}$ & **Taber \\
\hline VE & **Triana \\
\hline $\mathrm{E}$ & $* *$ Triump \\
\hline M & *Victoria \\
\hline $\mathrm{E}$ & *Waldo \\
\hline
\end{tabular}

$\underset{\mathrm{VE}}{\mathrm{E}} \underset{\mathrm{V}}{\mathrm{L}}$

\section{LIST E.-Peaches for Other Sections of the United States}

Adapted to most of the Peach sections of the country outside of the regions previously listed.

\begin{tabular}{lr|lr|lr|lr} 
**Alexander & $\mathrm{VE}$ & Estella & $\mathrm{L}$ & Imperial & $\mathrm{E}$ & Taber & $\mathrm{E}$ \\
*Belle of Georgia & $\mathrm{M}$ & Florida Gem & $\mathrm{E}$ & *Mamie Ross & $\mathrm{E}$ & Triana & $\mathrm{E}$ \\
**Carman & $\mathrm{E}$ & Gibbons' October & $\mathrm{L}$ & Onderdonk & $\mathrm{M}$ & **Triumph & VE \\
Colon & $\mathrm{E}$ & **Greensboro & $\mathrm{VE}$ & Pallas & $\mathrm{E}$ & Victoria & $\mathrm{L}$ \\
**Elberta & $\mathrm{M}$ & & & &
\end{tabular}

\section{VARIETIES OF PEACHES DESCRIBED}

The abbreviations in parentheses below, following the names of varieties, indicate the race to which they belong. Thus (Sp.) means that the variety belongs to the Spanish race; (Per.) to the Persian race; (N.C.) Northern Chinese; (Hon.) Honey; (P.-to.) Peen-to; (O. B.) Oriental Bloods. The dates given for the usual time of ripening are based on northern Florida.

Alexander. (Per.) Large; highly colored; flesh greenish white, juicy, vinous, of fair quality; cling. One of the earliest of the Persian type. About June I.

Angel. (P.-to.) Large, rounded, slightly pointed; color yellow, washed with red, very handsome; flesh white, sweet, melting, juicy, subacid, of exquisite flavor, entirely lacking in bitter-almond flavor; freestone. The tree bears while young, and is very prolific. It blooms a month later than Peen-to, thus escaping injury from frost in many sections. June 20 to 30 .

Belle of Georgia. (N. C.) Very large; skin white, with red cheek; flesh white, firm and of excellent flavor; fruit uniformly large and showy; free. Rapid grower; prolific. July I to I 5.

Carman. (N. C.) Of large size, resembling Elberta in shape; skin creamy white or pale yellow, with deep blush; flesh tender and of fine flavor; juicy freestone. Prolific bearer and profitable market variety. June ro to 20.

Colon. (Hon.) Large, roundish oblong; skin white, overspread with red; flesh white, streaked with red, sometimes almost solid red; very juicy, subacid, high-flavored, delicious; freestone. Remarkable among Honey derivatives for its snap and tone. Good grower and prolific. Introduced by ourselves in 1893-94. June 15 to 25 . 


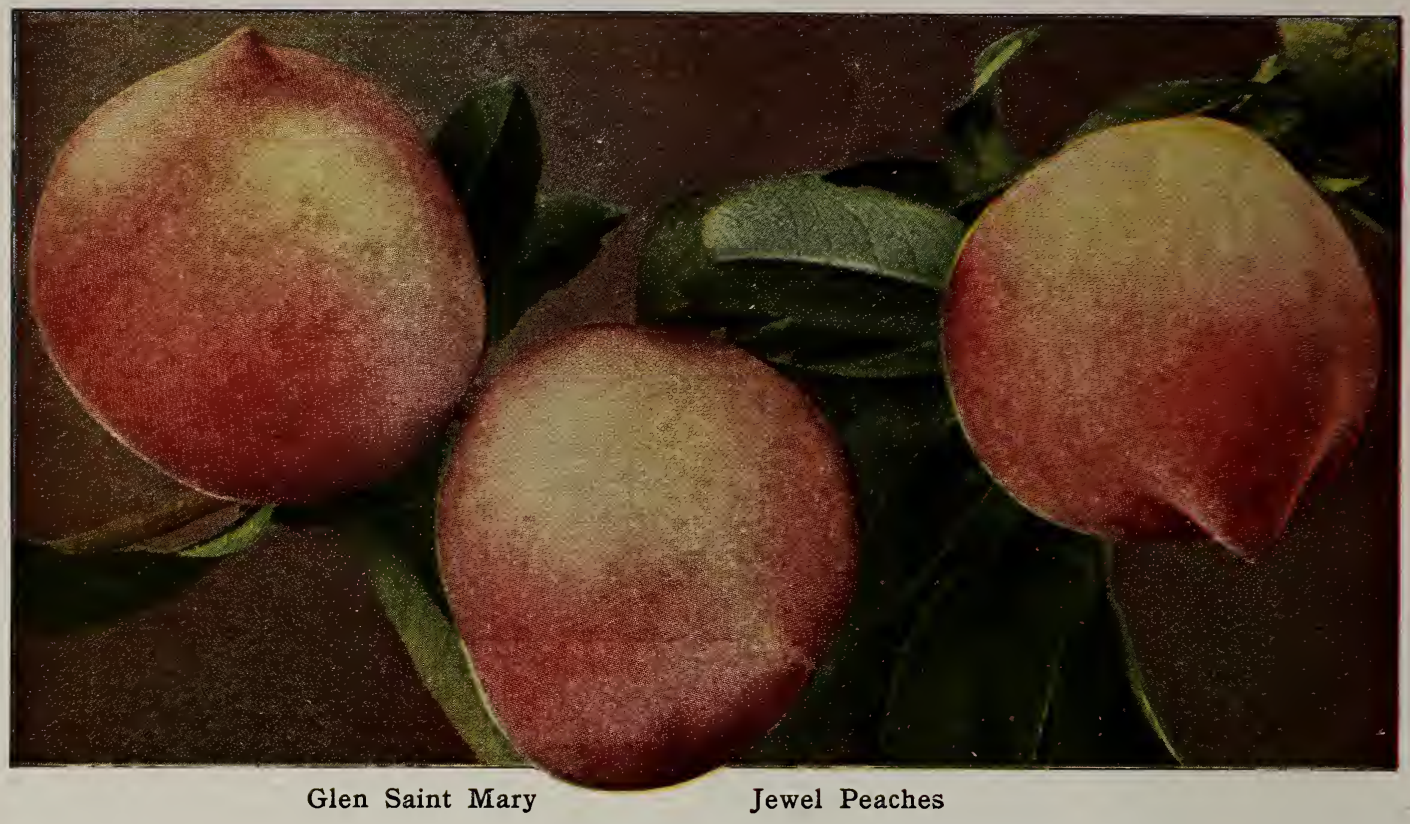

Imperial. (Hon.) Very large, roundish, oblong; skin greenish yellow, washed with red; flesh white, sweet, juicy, of excellent flavor and good tone; quality best; iree. Originated by ourselves. June 25 to July 5 .

Jewel. (P.-to.) Medium to large; rounded to oblong; highly colored, red on exposed parts; flesh yellow, red about the pit, juicy, melting, sweet; excellent quality; freestone. Ripens about two weeks earlier than Waldo. A good shipper; tree very vigorous and healthy. This is the most valuable market variety for southern Florida and all tropical and subtropical regions. It stands without an equal as the commercial market variety for these sections. We introduced this variety years ago and have made it one of our special lines of stock ever since.

Luttichau. Size large; oval, with medium deep suture, rounded or blunt pointed at apex; color waxy greenish white washed or blushed with red, dotted on shaded specimens; skin thin, tough; flesh white, red at pit, solid, juicy, flavor sweet, quality excellent; pit medium-sized, free; a splendid shipper. Season May 25 to June ro. This fine Peach originated on the place of Baron H. von Luttichau, Earleton, Fla., a number of years ago. Mr. von Luttichau propagated from it and planted an orchard of his own which proved very profitable, the fruit bringing the top price wherever marketed. Originated in the same region as Jewel, Waldo and Angel. We have known this variety for years, are well acquainted with its merits and regard it as one of the finest commercial Peaches for Florida. (See page 22.)

Mamie Ross. (N. C.) A seedling of the Chinese Cling which it much resembles. Fruit

almost as large as the Chinese Cling; white, nearly covered with delicate carmine; flesh white, juicy and of good quality. A regular and prolific bearer. Popular in Texas, where it is esteemed the finest early cling. June I 5.

Mayflower. (Per̈.) Large; well-colored; red all over; of fine quality; cling. A very promising variety. Its earliness, high color and excellent quality are strong points in its favor. Ripens four or five days earlier than Sneed.

Onderdonk. (Sp.) Large; skin and flesh yellow; very juicy and sweet; free. Originated in Texas. A valuable combination of quality, appearance and productiveness. Last of July.

Pallas. (Hon.) Good size, nearly round; deep red, dotted with salmon and tipped with light yellow at the base and apex; flesh white, fine-grained, melting, with a rich, vinous aroma; quality excellent; free. Seedling of Honey. Succeeds well along the Gulf Coast from Florida to southern Texas. June 20 to 30.

Peen-to. (P.-to.) A curiously formed Peach, flattened at both ends; color greenish white, washed with red on exposed parts; flesh light yellow, sweet, rich, juicy, of good flavor, with a slight bitter-almond flavor; cling, pit small, flat. Peen-to and its seedlings are among the most tropical Peaches. Ripens in northern Florida May 20 to June 3.

Suber. (P.-to.) Seedling of the Peen-to, originated at Lake Helen in southern Volusia County. Not materially different from Bidwell's Early, except that it is larger, firmer, and a little more acid than the latter. Tree is a vigorous grower, prolific, and the fruit brings a high price in market. 


\section{GLEN SAINT MARY NURSERIES}

\section{Deciduous Fruits}

Taber. (Hon.) Large, roundish, oblong, pointed; skin white, overspread with red; flesh white, streaked with red, firm, very rich, juicy subacid, of fine quality; cling. Honey seedling, prolific. Fine for canning. June $\mathrm{I}_{5}$ to 25 .

Triana. (Hon.) Medium to large, roundish oblong, slightly pointed; skin white, overspread with red; flesh white, with red markings, rich, juicy, very sweet and of fine flavor; freestone. This variety, originated by us several years ago, is one of the very best. June 25 to July 5 .

Triumph. (Per.) Ripens with Alexander; blooms late. Strong grower; bears young and yields abundantly. Fruit is of large size, with very small pit; skin vellow, nearly covered with red, dark crimson in the sun: flesh bright yellow, free when fully ripe, of excellent flavor.

Victoria. (Sp.) Very large, nearly round; skin yellow; flesh yellow, juicy, sweet, excellent flavor; free. One of the best native varieties, worthy of a place in every southern orchard. Fine for either cooking or canning. August 5 to ro.

Waldo. (P.-to.) Size medium, round, oblong; highly colored, light yellow, dark red on exposed parts; flesh yellowish white, red at the stone, juicy, melting, sweet, of excellent quality; freestone; prolific. Ripens with Peen-to. Valuable for Florida and the Gulf Coast country:

\section{JAPAN PERSIMMONS}

Since its successful introduction into this country in 1875 , the Japan Persimmon (Diospyros $\mathrm{Kaki}$ ) has been slowly but steadily gaining in favor. Since native Persimmon seedlings (Diospyros virginiana) are used as stocks on which to grow the Japan sorts, they can be grown on as wide a range of soil as the native Persimmon, and it is not too much to say that they will succeed with the minimum of care and attention with which any fruit may be successfully grown. At the same time, they respond generously to good care and cultivation. The trees are vigorous, prolific and have few enemies. The region in which the Japan Persimmon may be grown covers the cotton-growing belt. A carefully selected list of varieties will give fruit in abundance from August to December and later. During a very considerable portion of this period other fruit crops are out of season.

As we are experimenting largely with Persimmons and are the largest producers of these trees in America, important announcements may be looked for in our catalogues from year to year. For cultural and other notes, see our catalogues of I9II-I2-I3. (We have extra copies of these catalogues on hand, and shall be pleased to send them to anyone interested, upon request.)

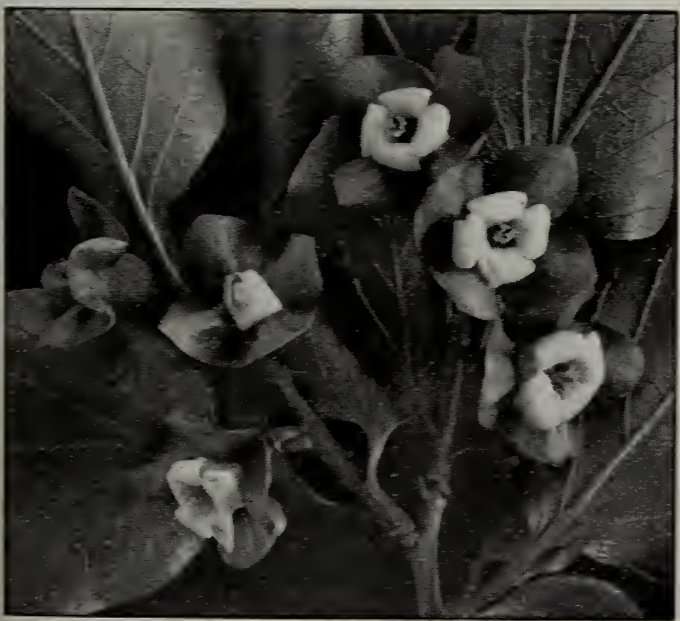

Pistillate Flowers of Costata Persimmon

Note how different they are from the staminate ones shown on page 30 .
At the meeting of the American Pomological Society in Washington, November, I9It, we were awarded a Wilder medal for our work with Persimmons.

\section{Persimmon Pollination}

One of the most puzzling things in the growing of Japan Persimmons has been the dropping of the blossoms and partly grown fruit. Trees of many varieties bloom prof usely, but, immediately following the blooming period, the young fruits begin to drop. This dropping usually keeps up until by harvest time no fruit remains on trees which should produce large crops. Here and there, from causes not understood, certain trees hold their crops, perhaps in some seasons and not in others. One variety only, the Tane-Nashi Persimmon, has held a crop of seedless fruit each time it bloomed. Naturally, many different explanations have been given for the behavior of Persimmon trees, and, to say the least, manyplanters have often been discouraged over their behavior, and have lost interest in them entirely. 


\section{SOUTHERN PLANTING FACTS}

\section{Deciduous Fruits}

\section{Cause of Dropping}

In 1909 we discovered the cause of the dropping of immature fruits, and from then until now much time and study have been given to the problem. The results secured have been checked and re-checked, proved and proved again, in these six years; not once, but literally thousands of times, until we now know the cause of dropping and how to prevent it. This information might have been given to the public a number of years ago, but, following our usual custom, we have taken time to make sure. We are particularly pleased to be able to do this, becalise we regard the Persimmon as a very valuable fruit, and it should have a much larger place in southern fruit-growing. Our discovery makes possible the successful culture of the Persimmon.

If the flowers of the Costata Persimmon, for instance, are examined (see page 24), it will be noted at once that there is no pollen in these flowers to fertilize the pistils and cause seed to form and fruit to set. This was the first point we discovered. Then, in April, 1909, we found that another kind of flowers was sometimes borne on Japan Persimmon trees. These were entirely different in shape, smaller in size, and contained stamens with plenty of pollen. Only three staminate flowers were found that spring, but the pollen in those three flowers was applied to a number of blossoms of varieties which would not hold their fruit, and these held and matured into perfect fruits. The next spring the tree which produced the staminate flowers in 1909 produced no staminate flowers; but, fortunately, other trees were found from which pollen was secured for hand-work, and a large number of flowers were hand-pollinated. A very large percentage of these developed into fruit, while flowers on the same trees not pollinated dropped, as usual. In the spring of I9I I more than 20,000 hand-pollinations were made, and the results in the setting of fruit were all that could be wished. But as yet we had no variety of Persimmon that we were sure would produce staminate flowers every time it bloomed.

\section{A Constantly Staminate Kaki Found}

In 1909 , on a piece of land near Eagle Lake, Florida, which we purchased from T. J. Gailey, we found a Persimmon tree, now named Gailey, which had produced staminate flowers in 1908 . It produced them in 1909 , and has been producing them each spring since that time. Many hundreds of trees have been propagated from it and brought into flower. These, also, have produced staminate flowers without fail. This variety has been tested out in the orchard, and the pollen from its flowers, carried by bees and other insects, has caused good crops of fruit to set. Nothing now remains to be done except to change our orchard practice, and plant trees to furnish pollen. We have ten other sorts under test, which, at one time or another, have borne staminate flowers, and some of them may be introduced later, but the Gailey Persimmon is the only one, so far, that we have tested long enough to satisfy ourselves that it will produce staminate flowers every time it blooms. Pollen from native staminate Persimmon trees (Diospyros virginiana) will not help. We have proved that beyond question by many hundreds of hand-pollinations. 


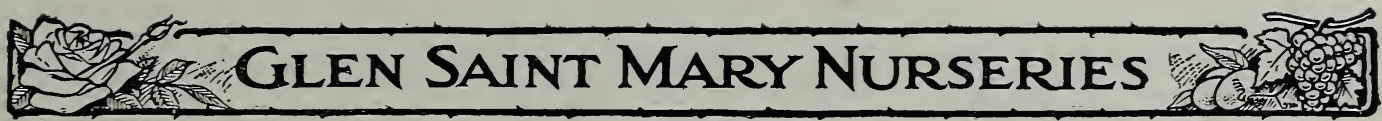

Deciduous Fruits

\section{Gailey Persimmon Introduced}

We introduced the Gailey Persimmon in I9I5. It is not recommended for its fruit, for, though good, it is small, but it is introduced to be planted along with other varieties to supply their flowers with pollen and insure crops of fruit. One tree of Gailey should be planted with every seven or eight of every variety of our list, except Tane-Nashi. Tane-Nashi will hold fruit without pollination.

Now, it must not be expected that the presence of Gailey trees in an orchard will cause every flower to set fruit. It would be a misfortune if it did that, for the trees would be so overloaded that they could not thrive. Neither will they take the place of good care, good cultivation, cover-crops and fertilizer; but, given these, Gailey will insure crops of fruit on Japan Persimmon trees.

PRICES ON PERSIMMONS.

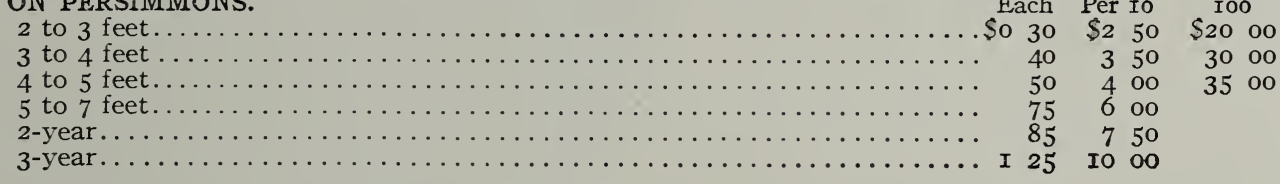

\section{New Persimmon, Fuyugaki}

In connection with our Persimmon investigations which led up to the discovery of why the trees dropped their fruit, and the introduction of staminate Persimmon varieties, we introduced and have tested a very large number of varieties from different parts of the world. Among these Persimmons was one sent us by the section of Seed and Plant Introduction, U. S. Department of Agriculture, Washington, D. C., in I9I3, under the name Fuyugaki. This variety possesses several characteristics which place it in a class by itself. So far as our observation goes it is never astringent, it is always light fleshed. it is edible while still hard and may be peeled and eaten like an apple. It keeps well, and in quality it is one of the very best. The fruit is of medium size, rather flattened, beautiful deep red in color, and the tree is very prolific. We believe this variety will surpass all other Japan Persimmons so far introduced as a market fruit. It can be placed on the market while still hard, and can be eaten without waiting for the fruit to soften.

PRICES ON FUYUGAKI PERSIMMON.

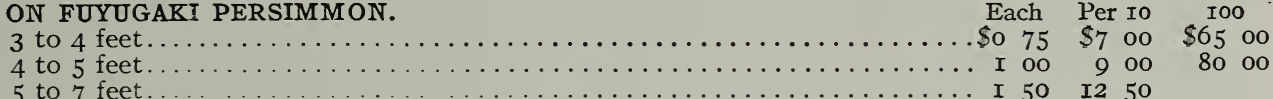

\section{VARIETIES OF PERSIMMONS DESCRIBED}

Costata. Medium size, conical, pointed, somewhat four-sided; diameter $2 \mathrm{I} / 8$ inches longitudinally and $25 / 8$ inches transversely; skin salmon-yellow; flesh light yellow, dark flesh and seeds occurring seldom; astringent until ripe, then very fine; one of the latest to ripen; a good keeper. Tree distinct; a rapid, upright grower.

Gailey. Small, oblate-conical, apex rounded, with small sharp point often marked with circular lines; color dull red, surface pebbled; flesh dark about the seeds, meaty, firm, juicy; seeds flat, oval, rather long. This variety is noteworthy for the production of staminate flowers for the pollination of the pistillate flowers of other varieties. Original tree on our grounds near Eagle Lake, Fla. A new and valuable introduction, recommended for its flowers, but not for its fruit.

Hachiya. Very large, oblong, conical, with short point; very showy; diameter $33 / 4$ inches longitudinally and $31 / 2$ inches transversely; skin bright dark red, with occasional dark spots or blotches and rings at the apex; flesh deep yellow, with seed. Astringent until ripe, then very fine. The largest and handsomest of all. Tree vigorous.

Hyakume. Large to very large, varying from roundish oblong to roundish obiate, but always somewhat flatteined at both ends; generally slightly depressed at the point opposite the stem; diameter $23 / 4$ inches longitudinally and $3 \mathrm{~T} / 8$ inches transversely; skin light buff-yellow, nearly always marked with rings and veins at the apex; flesh dark brown, sweet, crisp and meaty, not astringent; good while still hard. The tree is of good growth and a free bearer.

Masugata. A variety of Japanese origin; very free-flowering, producing an abundance of 
staminate flowers. Its blooming season overlaps with Gailey, and the two together give a longer season of staminate flowers. The fruit is of medium size, dark-fleshed and of good quality.

Okame. Large, roundish oblate, with well-defined quarter marks, point not depressed; diameter $23 / 8$ inches longitudinally and $31 / 8$ inches transversely; skin orangeyellow, changing to brilliant carmine, with delicate bloom and waxy, translucent appearance; light clear flesh when ripe, with light brown center around the seeds, of which it has several; loses its astringency as soon as it begins to ripen; quality fine. Tree strong, vigorous in growth and a good bearer.

Ormond. Small to medium, $25 / 8$ by I $7 / 8$ inches, conical, smooth; apex tapering, sharp, not creased, or only slightly marked; base rounded to the firmly attached, strongly reflexed calyx; color deep bright red with thin bloom; skin thin, tough; flesh orange-red; meaty, or jelly-like when fully ripe; seeds large, long, pointed. Quality very good. Ripens late (December) and may be kept for a long time after being gathered.

Taber's No. 23. Medium oblate, flat or depressed point; $1 \mathrm{I} / 8$ inches by $23 / 8$ inches; skin rather dark red, with peculiar stipple marks; flesh dark brown, sweet and free from astringency; seeds; good. Prolific.

Taber's No. 129. Medium, roundish, flattened at base; has a small but well-defined point at the apex; diameter about $23 / 8$ inches both ways, skin dark yellow-red, with peculiar, roughened surface, somewhat resembling alligator leather; flesh light brown, crisp, sweet, free from astringency; excellent; a good keeper and shipper. Vigorous, prolific, regular bearer.

Tamopan. Fruit large to very large, specimens often weighing one pound each; flattened, oddly marked by constriction about the middle; color golden red; fruit astringent until fully ripe; quality very fine; a vigorous grower and makes a large tree. Introduced from China by $\mathrm{Mr}$. Frank N. Meyer.

Tane-Nashi. Large to very large, roundish, conical, pointed, very smooth and symmetrical; diameter $31 / 4$ inches longitudinally and $33 / 8$ inches transversely; skin light yellow, changing to bright red; flesh yellow and seedless; quality very fine; perhaps the most highly esteemed of the light-fleshed kinds. Vigorous; prolific. The most desirable market variety.

Triumph. Medium, tomato-shaped; skin red; flesh yellow; generally has a few seeds;

very productive; quality best. Ripens from September to December. Excellent for home use or for market.

Tsuru. Large, slender, pointed; longest of all in proportion to its size; diameter $33 / 8$ inches longitudinally and $23 / 8$ inches transversely; skin bright red; flesh orange-yellow, astringent until fully ripe, quality good. Ripens very late. Tree vigorous; good bearer.

Yeddo-Ichi. Large, oblate; diameter $21 / 2$ inches longitudinally and 3 inches transversely; very smooth and regular in outline, with dintedappearing surface and slight depression at end opposite the stem; skin darker red than most varieties, with heavy bloom; flesh very dark brown verging toward purplish; sweet, rich, crisp; in quality one of the best. Edible when still hard.

Yemon. Large, flat, tomato-shaped, somewhat four-sided; diameter $21 / 4$ inches longitudinally and $31 / 4$ inches transversely; skin light yellow, changing to a dull red, mottled with orange-yellow; distinct in color; quality fine; flesh deep, dull red, brown around the few seeds. Some specimens are light-fleshed and seedless.

Zengi. The smallest of all; round or roundish oblate; diameter $\mathrm{I} 3 / 4$ inches longitudinally and $2 \mathrm{I} / 4$ inches transversely; skin yellowish red; flesh very dark, quality good; seedy; edible when still hard; one of the earliest. Vigorous and prolific. 


\section{GLEN SAINT MARY NURSERIES}

\section{Deciduous Fruits}

\section{PLUMS}

In the extreme South, particularly in central and south Florida, southern Texas, and, in fact, all along the Gulf Coast, the pure-bred Japanese varieties have not been good bearers, consequently were not generally profitable. But cross-bred varieties-Japanese varieties crossed with native varieties - have proved heavy annual bearers. These cross-bred varieties have made commercial Plum-growing not only possible, but worthy the attention of fruit-growers even in south Florida and northern Mexico. Of these cross-bred Plums we can heartily recommend Excelsior, McRea and Terrell. These are excellent kinds, heavy bearers, and have given our customers satisfaction over a very wide range of territory.

PRICES ON PLUMS.-On Marianna Plum Stock. $\quad$ Each Per Io Ioo

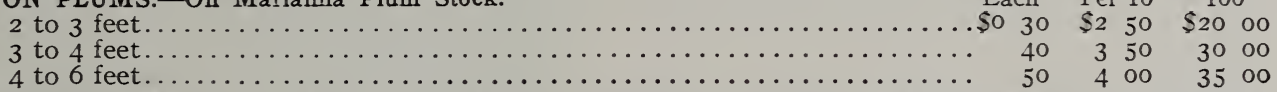

Abundance. Medium to large; round with vigorous, upright branches with large leaves. blunt-pointed apex; pinkish red changing to purplish red with thick bloom and numerous medium-sized dots; flesh greenish yellow, juicy, sweet or slightly subacid; pit small; cling; quality best; prolific; strong grower. A popular and profitable early Plum for planting in northern sections and in many parts of the South.

Burbank. Size large to very large; rounded and blunt-pointed; dark red, mottled, over yellow ground; thick bloom and numerous large dots; flesh deep yellow, juicy, sweet, firm; pit small; cling; quality one of the best. Tree very

Very popular both North and South.

Chabot. Fruit large, about 2 inches in diameter, oblong-conical; color pink-red, with numerous small dots; flesh yellow, solid, tart; cling; quality very good. Tree vigorous in growth.

Kelsey. Size very large; heart-shaped, longpointed, usually lop-sided with deep suture; color greenish yellow sometimes flushed with red covered with thick, bluish bloom; very showy flesh light yellow, meaty; flavor rich, pleasant quality excellent; prolific and bears while young. Highly recommended.

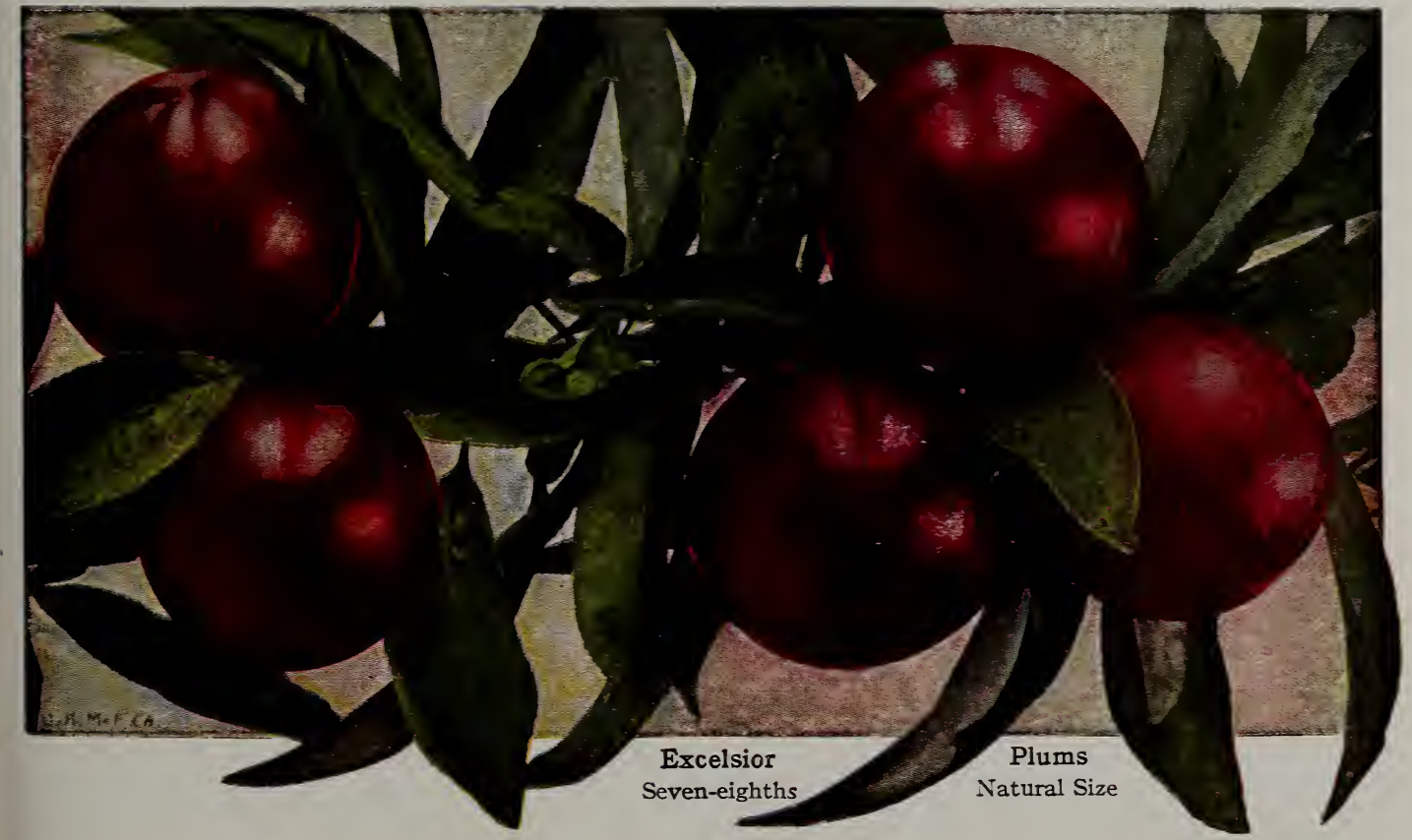




\section{SOUTHERN PLANTING FACTS}

\section{Deciduous Fruits}

McRea. (Hybrid.) Fruit of medium size, flattened, rounded, oblique at apex; yellow undercolor washed with dull red, dotted with small, light dots and covered with delicate bluish bloom, flesh yellow, juicy, subacid, firm; flavor aromatic, pleasant; quality excellent; prolific, good grower. We believe this Plum well worthy of extensive planting.

Persian Purple-leaved (Prunus Pissardii). Fruit medium, round; color of fruit and flesh crimson; quality good, cherry-flavored. Tree a good grower; valuable as an ornamental, as it retains its vivid purple foliage until late in the season.

Red June. Fruit medium to large, cordate, elongated at the apex, lop-sided; suture deep; color vermilion-red all over with delicate bloom; very showy; flesh light, yellow, firm, moderately juicy, sweet or slightly subacid; pit small; cling; flavor pleasant; quality very good. Tree vigorous and prolific. A good variety.

Satsuma. Medium to large, broadly conical, with blunt, short point and deep suture; color dark, dull red all over with greenish dots; flesh purplish red; pit small; free; firm, juicy; quality excellent; a splendid keeper and good shipper; fine for preserving. A desirable variety.

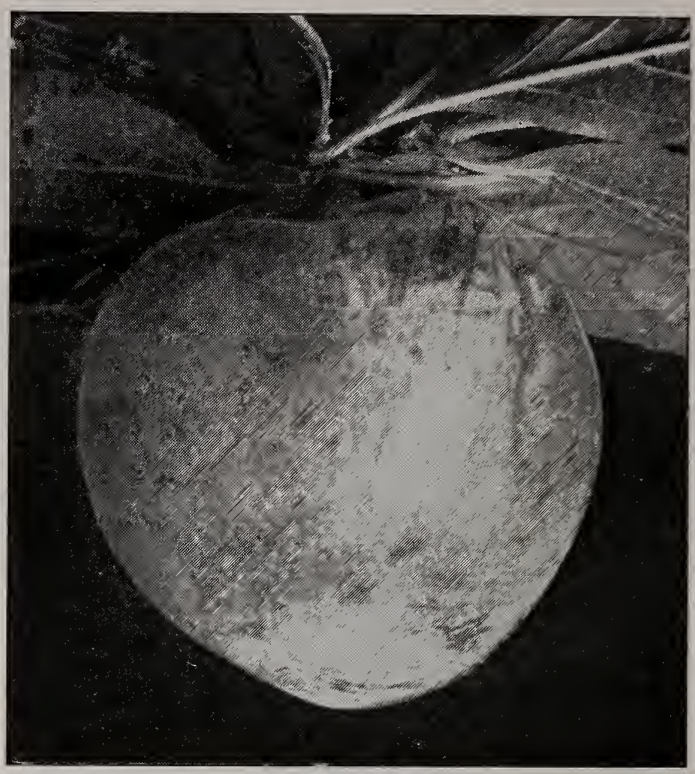

Terrell Plum

Terrell. (Hybrid.) A strong, healthy grower; very similar in habit to Excelsior; fruit large, I I 2 to 2 inches in diameter, nearly round, blunt-pointed; color a beautiful reddish yellow, mottled, covered with bloom, wine-colored when fully ripe; flesh greenish yellow, meaty, juicy, slightly subacid; pit small; cling; quality excellent. Recommended as one of the finest Plums for Florida and the Gulf Coast country. It is giving a good account of itself.

\section{Excelsior Plum}

(See illustration, page 33)

This Plum originated at the Glen Saint Mary Nurseries in 1887 , and, first offered to the public in the winter of $189 \mathrm{I}-92$, is today the most noteworthy Plum in the belt comprising northern Florida and the southern part of the Gulf States around into Texas. It originated from seed of the Kelsey Plum and was selected out of a number of Kelsey seedlings by Mr. G. L. Taber.

Excelsior shows decided evidence of being crossed with some variety of the Chickasaw type, and is a well-marked hybrid. The tree is a remarkably rapid, vigorous grower, and bears heavy crops of fruit annually. The trees are often so loaded with fruit that the branches must be propped to prevent breaking. It is a very dependable sort.

Fruit medium large, $\mathrm{I} / 2$ inches in diameter, nearly round, no suture; color deep wine-red, with thick, bluish bloom and very numerous small dots; when fully ripe the fruit is almost purplish red; stem short; skin thin, tough, not bitter nor astringent; flesh firm, juicy, yellowish with reddish color near the pit; quality excellent, flavor subacid; pit small; cling. The earliest Plum to ripen in Florida-about June I to ro. Very handsome, and a fine shipper. More fruit of this variety is grown throughout northern Florida than of all other varieties of Plums put together.

After many years of experimenting with numerous sorts of Plums, we do not hesitate to say that Excelsior, Terrell and McRea are the most satisfactory varieties for planting throughout the length and breadth of Florida, and throughout the Gulf Coast country westward to the Rio Grande River. While adapted to this extreme range of latitude, we particularly recommend them for the extreme South, as they are among the few really fine Plums that do well in semi-tropical climates. 


\section{GLEN SAINT MARY NURSERIES}

\section{Deciduous Fruits}

\section{FIGS}

No fruit is more valuable in the southern fruit-garden than Figs. They can be closely plantedIo to I 2 feet apart-and yield heavily. The Fig-canning industry is gradually extending throughout the South, and since several tons of fruit can be produced on an acre of ground, it is well adapted to intensive culture. The preserved product put up at the present time in no wise supplies the demand, and we look for a very material increase in the Fig-canning industry.

The fresh Fig is also finding its way into the markets, and meeting with a ready sale. Carefully picked at the right stage of maturity and packed in strawberry crates, they can be placed by express in distant markets, four or five hundred miles, or even more, in good condition.

Figs come into bearing very early, and for that reason commend themselves to the fruit-grower. IVith a proper selection of varieties, fruit may be secured from June to November. Figs often succeed best when planted so the roots may run beneath buildings. Orchard plantings should be made on heavy soils, clay soils, or on lands where the clay is very close to the surface.

Figs succeed best with little or no cultivation and such cultivation as is given should be very shallow because the roots are close to the surface. Mulching gives satisfactory results because it supplies needed vegetable material as it decays and keeps the roots cool and moist.
PRICES ON FIGS.

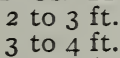

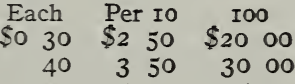
4 to $5 \mathrm{ft}$.
$50 \quad 4$ o0 35 o0

Brunswick. Fruit very large, broadly pearshaped, with short, rather slender stalk; ribs well marked, eye large, open, with rosy scales; skin tough, dark brown in color; pulp thick, soft, quality very good. Satisfactory variety.

Brown Turkey. Size medium to large; broadly pear-shaped, with short, thick stalk; ribs few in number; color coppery brown; flesh white, or slightly amber-colored, shading to pink about the seeds; flesh solid, excellent quality. This variety ranks with Celeste in hardiness. It is very hardy and desirable.

Celeste. Small to medium, pear-shaped, ribbed; violet-colored, sometimes shading to purplish brown, covered with bloom about half way up from the neck; stem short, stout. Flesh whitish, shading to rose-color at center; flesh firm, juicy, sweet, excellent quality. One of the hardiest varieties of Figs, and can be grown far outside of the usual limits of culture; very desirable for canning and preserving.

Green Ischia. Fruit of medium size, long; pulp rosy red, soft, melting, quality rich, sweet. A variety of very high quality. The tree is a strong grower.

Lemon. Fruit medium to large, flattened, faintly ribbed, light yellowish green; stem short, stout; flesh white, sweet, rather soft, quality fair to good; season July. Very vigorous and prolific.

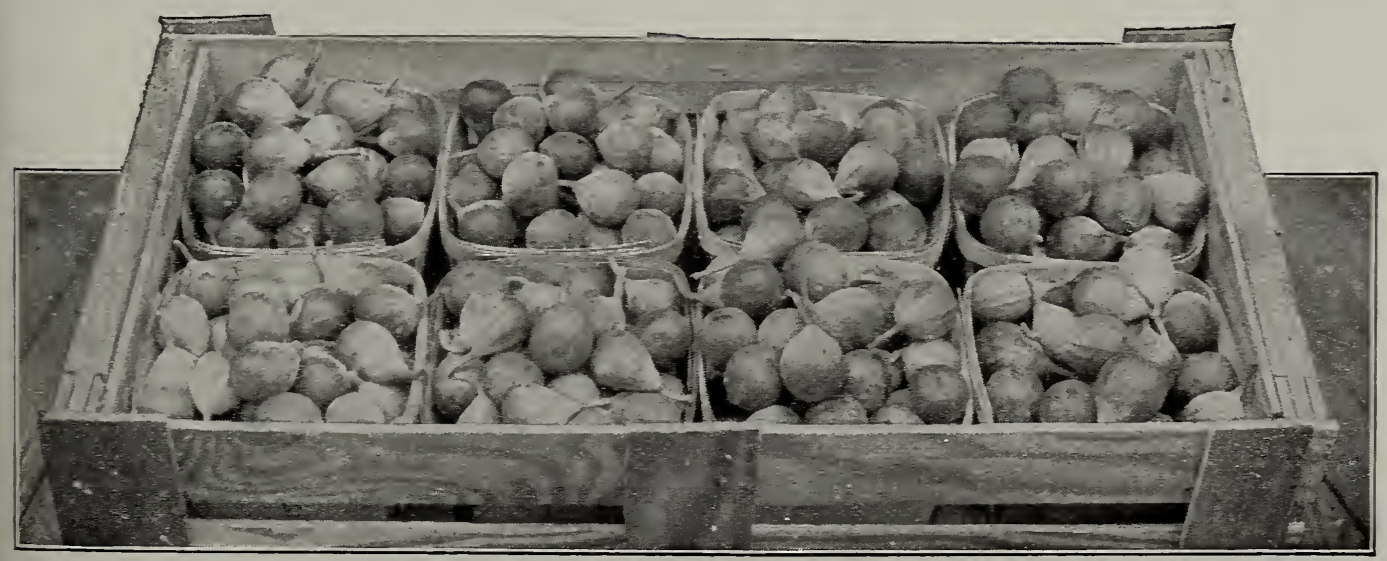




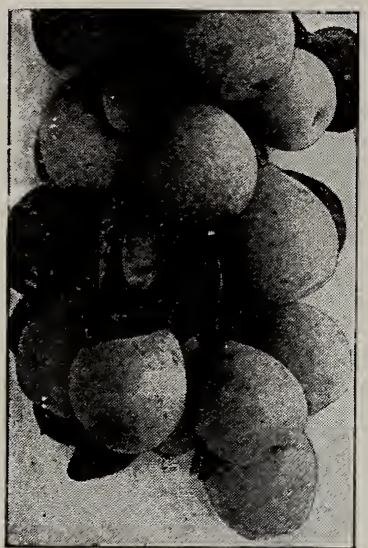

Le Conte Pears

\section{PEARS}

In recent years the Pear crop has been bringing splendid returns. There has been a steady upward trend in prices until, even with a short crop occasionally, it pays to grow Pears. At prices ranging from six to twelve dollars per barrel it does not take a heavy yield to pay good returns.

The most serious drawback in growing Pears is pear blight, but the oriental Pears such as Kieffer, Garber and Le Conte are not nearly so subject to it as the European Pears. With careful attention to pruning, fertilizing and cultivation, these Pears are quite free from blight. This group of oriental Pears is the very best for planting in the South. No cultivation should be given more than to cut down the grass and weeds around the trees. The fertilizer used should

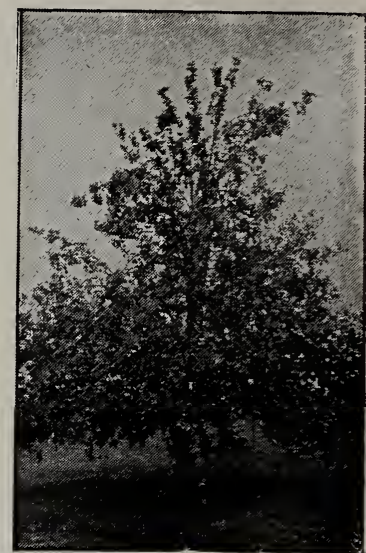

Kieffer Pear Tree contain but little nitrogen or ammonia and should be rich in potash. This practice produces hard, firm wood-growth, and such growth is not nearly so subject to injury. Dead or blighted branches should be cut well below the line between dead and living wood. These prunings should be burned. PRICES ON PEARS.-On Japan Seedling Pear Stock.

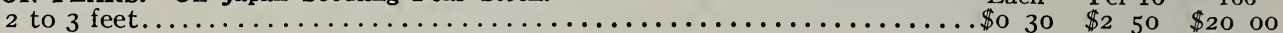

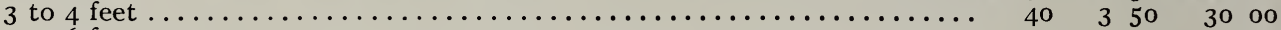

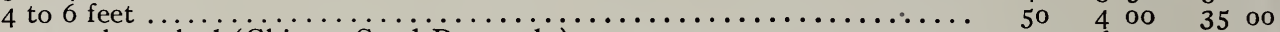
2-year, branched (Chinese Sand Pear only)................. 75

Ghinese Sand. Fruit of medium size, roundish pyriform; yellow, slightly russet. A vigorous grower; free from blight; valuable for cooking.

Garber. Fruit resembles the Kieffer in size, appearance and quality, but the tree is more open in growth. Comes in ahead of the Kieffer. A seedling of the Chinese Sand Pear.

Japan Golden Russet. Fruit of good size, round; russet; flesh is tender, juicy and of fine flavor. A strong, vigorous grower; ripens later than the Sand Pear.
Kieffer. Fruit large to very large; yellow, with bright vermilion cheek, very handsome; flesh very juicy, brittle, a little coarse but of good quality. September and October.

Le Conte. Fruit large to very large, pyriform; skin smooth, pale yellow; quality good when properly handled. Season, July. A vigorous grower, prolific and regular in bearing.

Magnolia. Large to very large, slightly pyriform; glossy, reddish brown; flavor subacid. Later than Kieffer, and keeps well.

\section{GRAPES}

Grapes of the Muscadine group are native to the South, and are well adapted to the soil and climate. When compared with the Bunch Grapes, the fruit-clusters are small, but the fruit is fineflavored and valuable as a table Grape, for making unfermented grape-juice, preserves, jellies and wines. In Virginia and North Carolina they are extensively grown for wine-making.

Muscadine vines are long-lived, reaching a healthy, vigorous old age. They should be planted I 5 to 25 feet apart each way. The usual plan is to allow them to run on an overhead trellis, $61 / 2$ to 7 feet from the ground. The posts should be heart-pine, cypress or cedar. The trellis may be made of wood and wire, or of wood alone.

The usual plan, heretofore, has been to allow the Muscadine Grapes to grow without pruning but this is a mistake. It has been shown that, to secure the best results, the vines should be pruned. This is best done in October, immediately after the leaves have fallen. They may also be pruned in summer.

In the lower South, the northern Bunch Grapes, while not so thoroughly at home, can be grown to perfection for home use and for local market, when well cultivated, sprayed and cared for. The leading varieties are Delaware, Diamond, Ives, Moore's Early and Niagara.

The best trellis for the Bunch Grapes in the lower South is the Munson three-wire trellis. 


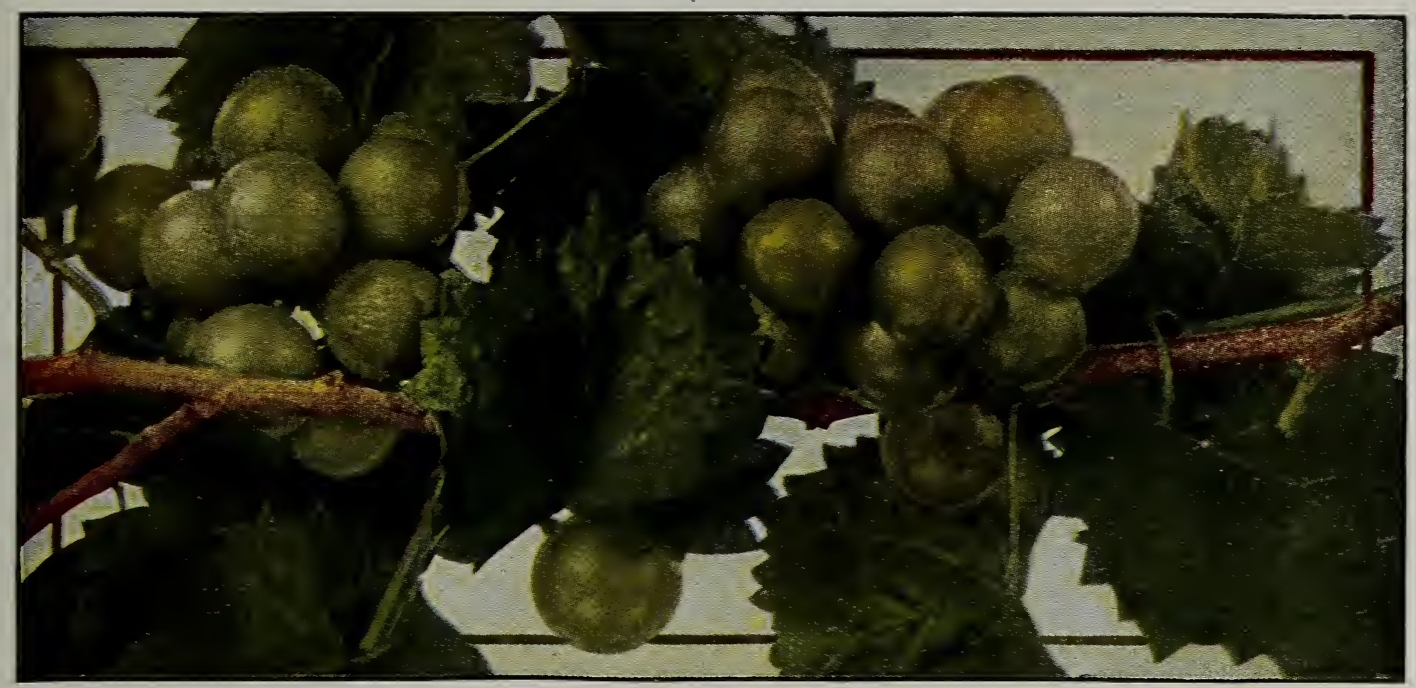

Scuppernong Grapes

The vines should be planted 8 to io feet apart. For the first season or two a post placed at each vine will be sufficient. Later the cross-pieces and three wires can be added, and the vines allowed to run out over them. Prune each winter season. Cut away a goodly portion of last season's growth, leaving four or five buds on each shoot. The best spray for the canes and fruit is bordeaux mixture. This should be applied several times each season, beginning soon after the growth starts in spring, with an application in winter, just after the pruning is done. It is an excellent plan to bag the bunches of fruit, using for this purpose two- or three-pound ordinary paper sacks.

PRICES ON GRAPES.-Muscadine and Bunch.

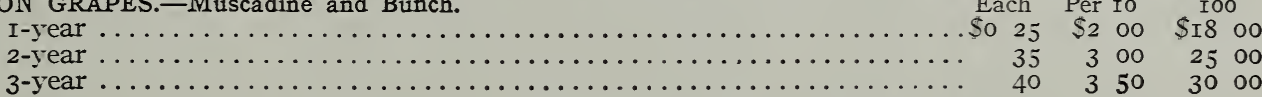

\section{Muscadine Grapes}

Flowers. Bunches composed of fifteen to twenty large, purplish black berries; sweet, vinous, good quality. Most largely planted variety of the Muscadine type. August and September.

James. Very valuable. The largest of the Muscadine group, berries often measuring $3 / 4$ to $I / 4$ inches in diameter; prolific; black, juicy, sweet. Has taken premiums wherever exhibited. Ripens from August until late in the fall.

Scuppernong. Muscadine type. Bunches composed of eight or ten very large berries, bronze-colored when fully ripe; flesh pulpy, sweet, with peculiar, agreeable, musky flavor; quality excellent. One of the oldest and best varieties of the Muscadine Grapes in cultivation. Strongly recommended for its good growing and bearing qualities. Ripens in August and September.

Thomas. Belongs to the Muscadine type, and one of the best of its class. Color reddish purple; pulp sweet, tender. Very largely planted. August and September.

Male Muscadine. Muscadine Grapes bear much larger crops if a pollen-bearing vine is planted near to furnish pollen.

\section{Bunch Grapes}

Concord. Bunches and berries very large, blue-black, with bloom; flesh sweet, pulpy, tender, good; vine vigorous. Heavy bearer; desirable for home markets. July.

Delaware. Bunches small to medium; berries small, skin red or pink, and very thin; sweet, juicy, vinous; quality best. Generally considered the finest American Grape.

Diamond. A handsome white Grape equal or superior to Niagara in quality, and ten days earlier. Prolific, very thrifty and vigorous, and one of the best for the South.

Ives. Strong grower; very productive; stands shipping well; bunch large; berries large, black, pulpy, sweet, of good quality. June.

Moore's Early. Similar to Concord in size and shape, but better and earlier. Well adapted to the South.

Niagara. Bunch and berry large; greenish yellow; flesh sweet; quality good. A strong grower and produces good crops of fruit. One of the best for the South generally.

Salem (Rogers' No. 53). Bunch large, compact; berry very large, round, coppery red; flesh tender, juicy, quality best. July. 


\title{
SOUTHERN PLANTING FACTS
}

\author{
Deciduous Fruits
}

\section{POMEGRANATES}

The Pomegranates are very hardy shrubs, which can be grown throughout the Gulf states and the coastal sections of Georgia and the Carolinas. The brilliant scarlet flowers are produced in profusion, and an abundance of fruit usually follows. The fruit is used in making jellies, marmalades and acid drinks. For this latter purpose they are highly esteemed. The fruit has a fresh crispness, and a delicate, sprightly flavor found in few fruits. As a commercial fruit, the Pomegranate is steadily gaining in favor.

They are valuable as ornamentals. The new shoots and leaves in early spring vary in color from light green to delicate pink and maroon. The showy flowers follow in early summer, and the fruit makes the shrubs attractive in autumn. They are adapted for planting singly or in groups and when well cared for the Pomegranates make good deciduous shade.

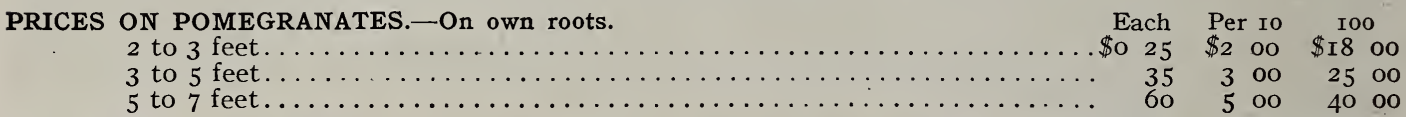

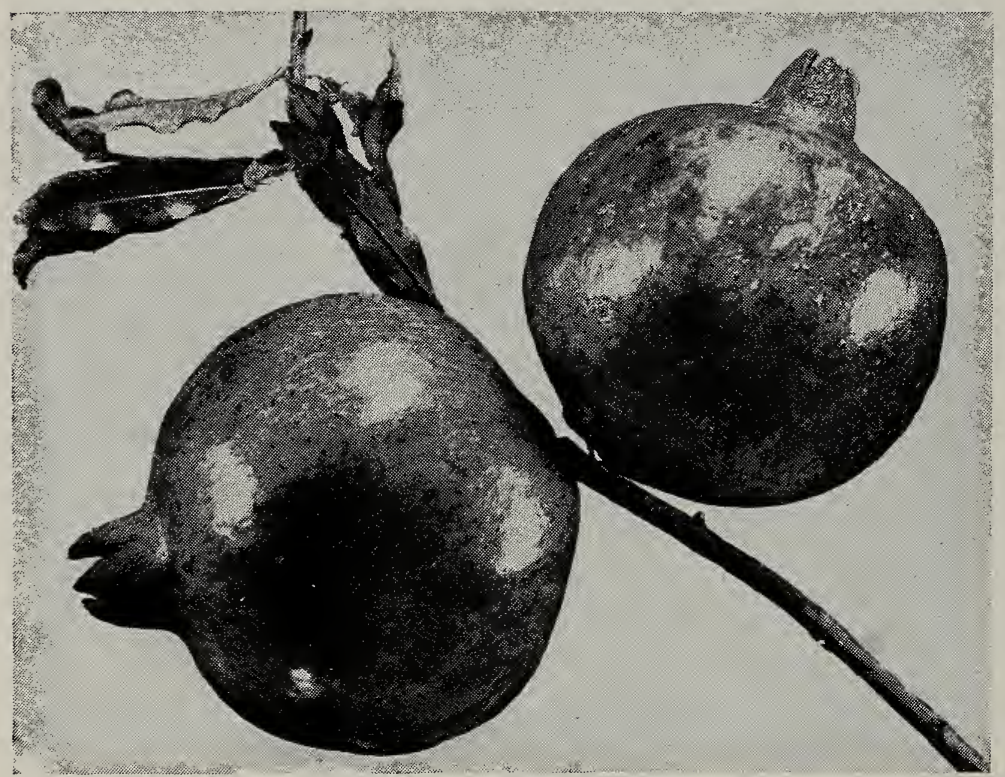

Rhoda Pomegranates ( $1 / 2$ natural size)

Purple-seeded. Large; rind thin; juice-cells surrounding the seeds dark ruby or wine - color; sprightly, vinous and of the best quality. A very choice variety, and one of the best for general culture.

Rhoda. Brought to our attention by one of our employees, who had been growing it for years. The fruit is of large size; rind thin but tough; juicecells large and of beautiful wine-color; crisp, sweet and of exquisite flavor.

Sweet. This variety has large, sweet fruit and is one of the best of the sweet group; handsome.

Wonderful. A new, fine, late-ripening sort, with large, highly colored fruit and beautiful pulp. Handsome and desirable.

\section{MULBERRIES}

The Mulberry is well adapted generally to Southern conditions, and no fruit tree is more valuable on the farm. Its wide-spreading branches afford splendid shade throughout summer, and it is without question the best shade tree for poultry-yards and hog-pastures. The fruit is readily eaten by poultry and pigs, and as some varieties continue in fruit for several weeks, or even months, it is no mean source of food-supply. Besides this, it is valuable for tolling birds away from other fruits, and no bird-lover should omit this tree from his plantings. Some varieties, Stubbs in particular, are valuable for home use. The fruit of this variety is acid enough to give it decided tone and to make it of value as a kitchen fruit for the making of jellies, jams and similar products. Under existing conditions increased plantings of Mulberries are worth considering. Their rapid growth soon brings them to bearing size. 


\section{GLEN SAINT MARY NURSERIES}

\section{Deciduous Fruits}

PRICES ON MULBERRIES.-On Mulberry stock.

\begin{tabular}{|c|c|c|c|}
\hline 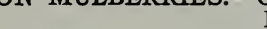 & $\mathrm{ch}$ & Per Io & 100 \\
\hline 2 to 3 & 20 & & $\$ 1200$ \\
\hline I-year, 3 & 25 & 200 & I5 00 \\
\hline I-year, 4 to 6 feet.. & 30 & 250 & 2000 \\
\hline vear $6 \mathrm{f}$ & 50 & 4 & \\
\hline
\end{tabular}

Hicks. Fruit sweet; tree grows rapidly and bears young; productive; should be grown by every farmer who keeps swine or poultry, this variety being of special value for this purpose; continues in bearing four months of the year, which makes it an exceptionally valuable variety.

Stubbs. Large, black; acid; excellent; prolific. Fruit from $\mathrm{I} / 2$ to 2 inches long, superior to any other. Tree vigorous and handsome. One of the best varieties.

Townsend. A new variety, which, on account of its extreme earliness, we have deemed worthy of propagation. Berries of medium size and fair quality. Should be planted where birds are apt to ruin other early fruits. Will be popular when better known. March and April.

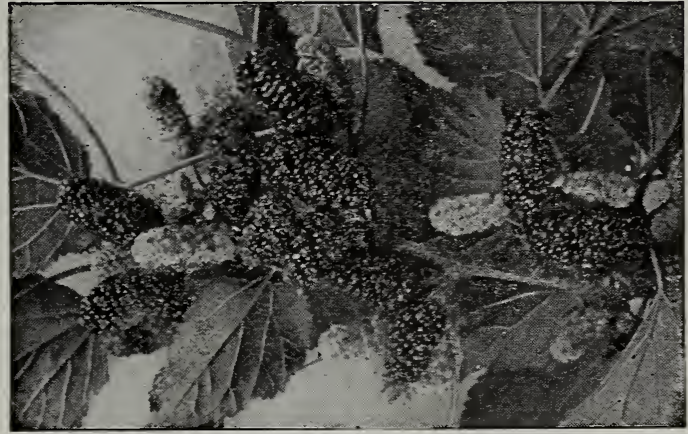

Stubbs Mulberry

Multicaulis (Morus multicaulis). The Silkworm Tree. A very vigorous tree, extensively used for propagation, shade, and for silkworms.

White. A white-fruited form, vigorous and prolific. Should be generally planted.

\section{APPLES}

While the Gulf region is not recommended for extensive Apple orchards for commercial purposes, yet, on its upper edge some varieties may be grown. The most successful results are secured by planting on heavy clay soils, or soils underlaid with clay, or on soils with a goodly supply of moisture, and which at the same time are well drained. Under most conditions the planting should not extend beyond a few trees for the home orchard. Our list is made up of those varieties which experience has shown will succeed farthest south.

PRICES ON APPLES.

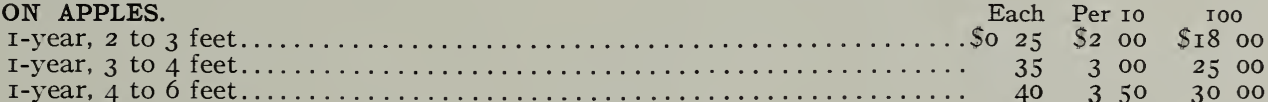

Ben Davis. Medium to large, roundish, truncated, conical; yellowish, overspread and striped or splashed with shades of red; subacid, of fair quality; good keeper. This variety is widely planted and popular.

Early Harvest. Medium to large; yellow, juicy, tender, of fine flavor. A well-known and popular variety. Ripens in June.

Red Astrachan. Large; crimson, with heavy bloom; flesh crisp, acid and juicy. Ripens in

June. Tree vigorous, bearing very young and regularly. Adapted to a wide range of climate.

Red June. Medium conical; deep red; juicy; very productive. A beautiful and thrifty tree. One of the best for the lower South.

Winesap. A very fine winter Apple, with white, firm, crisp flesh; color red or striped red. Fruit medium size; quality excellent. A very satisfactory Apple for southern planting; one of the finest grown in the Apple regions.

\section{QUINCE}

While the Quince does not succeed all over the whole lower South, yet it does well in many localities and should be planted. It naturally prefers a rather moist, loamy soil. IVe offer two of the best and most noteworthy varieties.

PRICES ON QUINCES.-On Quince stock.

Each Per I0

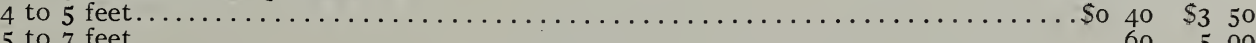

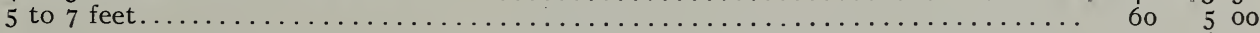

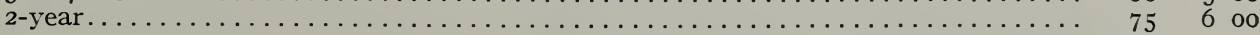

Orange. Large; golden yellow, with firm, tender flesh and excellent flavor. A strong grower and thrifty. One of the best for preserves.
Pineapple. One of Luther Burbank's introductions. Of large size, smooth and rounded. Fine for jelly, and cooks tender. 


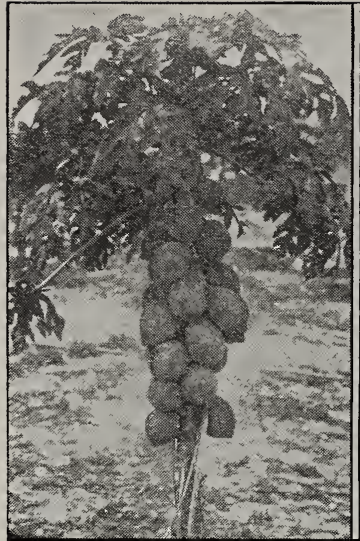

Papaya Tree

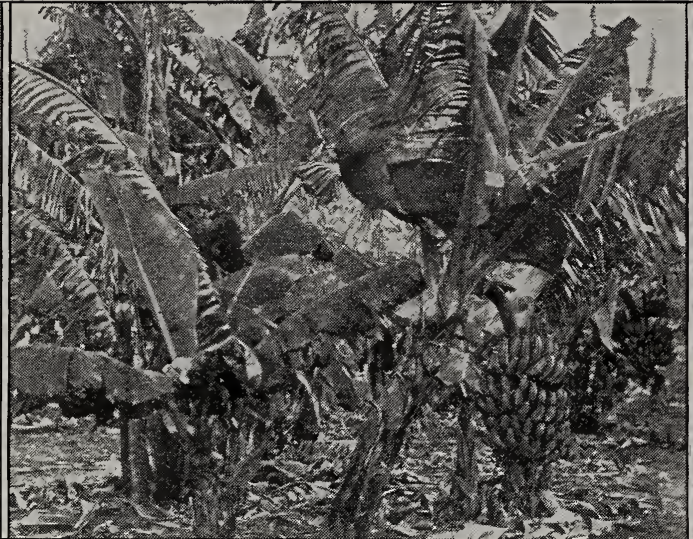

A Banana Planting

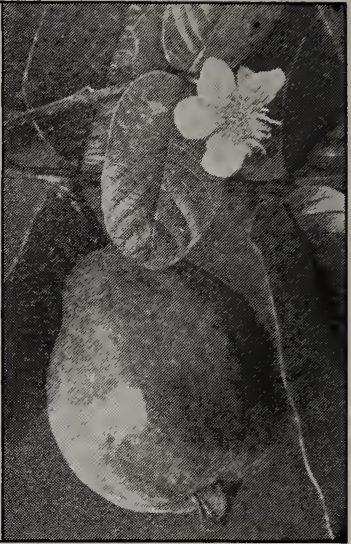

Guavas

\section{Tropical and Sub-Tropical Fruits BANANAS}

The Banana is a rapid-growing plant of great value for its fruit and for decorative purposes. It requires rather moist ground and plenty of plant-food for best results. Both stable manure and commercial fertilizer may be used. Very often there is a low, moist place that may be planted in Bananas to advantage, or they may be set on the shores of lakes or the banks of streams.

PRICES ON BANANA PLANTS.

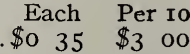

Medium suckers.

Large suckers.

Cavendish. A rather tender, dwarf variety, producing an excellent quality of fruit.

Hart (Hart's Choice, or Lady-Finger). A valuable hardy sort; fruit of fine quality.

\section{GUAVAS}

The Red Cattley and Yellow Chinese may be grown in north Florida as well as in more

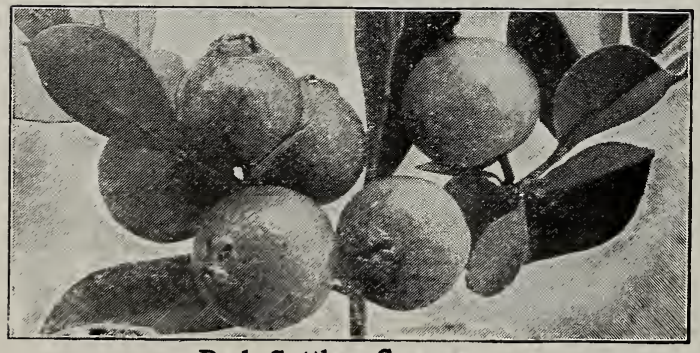

Red Cattley Guavas tropical sections. Excellent for use as dessert fruits or for making preserves and jellies. PRICES ON GUAVAS. $\quad$ Each Per to I to 2 feet.............. 50 50 $\$ 4$ oo 2 to 3 feet............... $75 \quad{ }_{6} \quad 50$

Red Cattley. A handsome evergreen shrub with glossy green leaves, producing large quantities of small red fruits, I to $\mathrm{I} / 4$ inches in diameter. It grows in north Florida. Seedlings only.

Yellow Chinese. Almost identical with the Red Cattley, except that the fruit is yellow instead of being red-fleshed. Both of the Cattley varieties are very desirable. Grown from seed.

\section{PAPAYA (Carica Papaya)}

This is one of the most remarkable tropical fruits. The fruit somewhat resembles a cantaloupe. As the plants are diœcious, about one-half of them will bear fruit and the remainder supply pollen to fertilize the blossoms. Under favorable conditions the pistillate plants will fruit in a few months after planting. They require plenty of plant-food, good drainage and sufficient moisture for best results. It is a continuous fruit-bearing plant, continuing in fruit without a break for months or even years. It makes a desirable ornamental and its odd fruiting habit always attracts attention.

PRICES ON PAPAYA PLANTS.-Pot-grown from seed of choice fruits.

Each Per Io

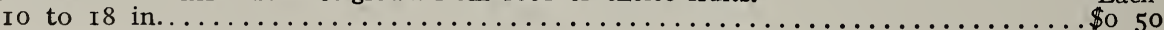

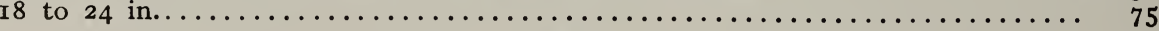

$\$ 4$ oo

650 


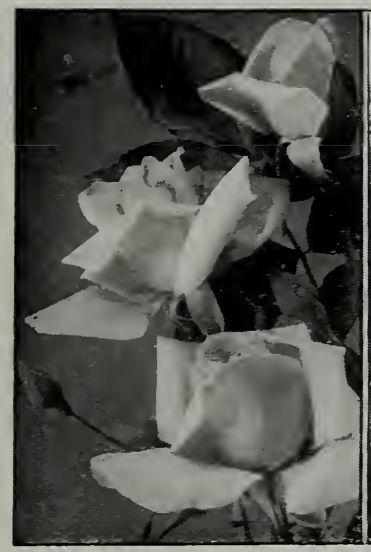

Safrano Roses

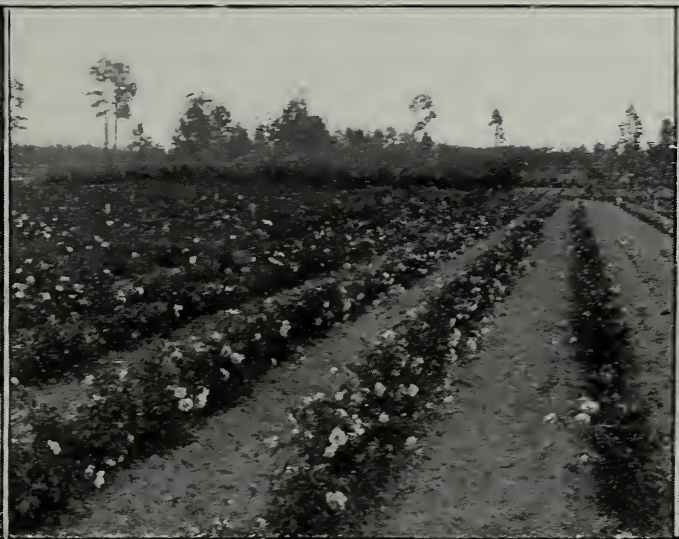

View in Rose Nursery

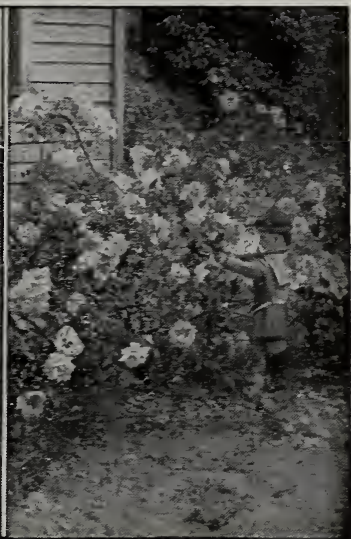

Solfaterre Rose Bush

\section{ROSES}

Roses are the most important flowering shrubs of the South. Nowhere in the country do they develop in such beauty or bloom in such profusion. No garden is complete without its Rose-bed, no planting scheme is perfect which does not provide a place for them.

With few exceptions, the most satisfactory results will be secured by planting Roses grafted on strong-growing roots. Nearly all Roses grown from cuttings are vastly inferior, producing poor, weak plants as compared with grafted specimens. Our Roses are strong, grafted plants, grown in the open field-the kind of Roses that give satisfaction. In planting, the graft-union should be placed two or three inches under the surface of the ground. Any shoots which come from the root below the graft-union should be promptly removed, as these are worthless and will soon injure the grafted Rose above.

Roses are gross feeders. Liberal applications of liquid manure during the blooming season will result in larger and more beautiful flowers.

CLIMBING ROSES are usually regarded as valuable only for porches or trellises. While useful for these purposes, they are often much more satisfactory as bush Roses. Climbing Roses are strong growers; given plenty of room and severely pruned, they produce an abundance of bloom never surpassed and not often equaled by the true bush Roses. The ability of a Rose to bloom depends on its ability to grow and produce new wood.

Roses are derived from a number of different classes. These classes are indicated by initial letters in parenthesis immediately following the name of the variety. The key to these classes is as follows:

Bk., Banksia; Beng., Bengal; Bour., Bourbon; C. B., Climbing Bengal; C. C., Climbing China; C. N., Climbing Noisette; C. T., Climbing Tea; H. C., Hybrid China; H. N., Hybrid Noisette; H. P., Hybrid Perpetual; H. T., Hybrid Tea; Mult., Multiflora; N., Noisette; Pol., Polyantha; T., Tea.

PRICES ON ROSES.-Grafted on strong-growing stock. I-year, strong, open- Each Per Io I00 ground-grown..... \$o $60 \quad \$ 5$ oo $\$ 40$ oo 2-year, large, strong,

open-ground-grown. $75 \quad 650 \quad 5000$ Specimen Roses, with ball of earth, $\$ 2$ each; see pages 46 and 47 .

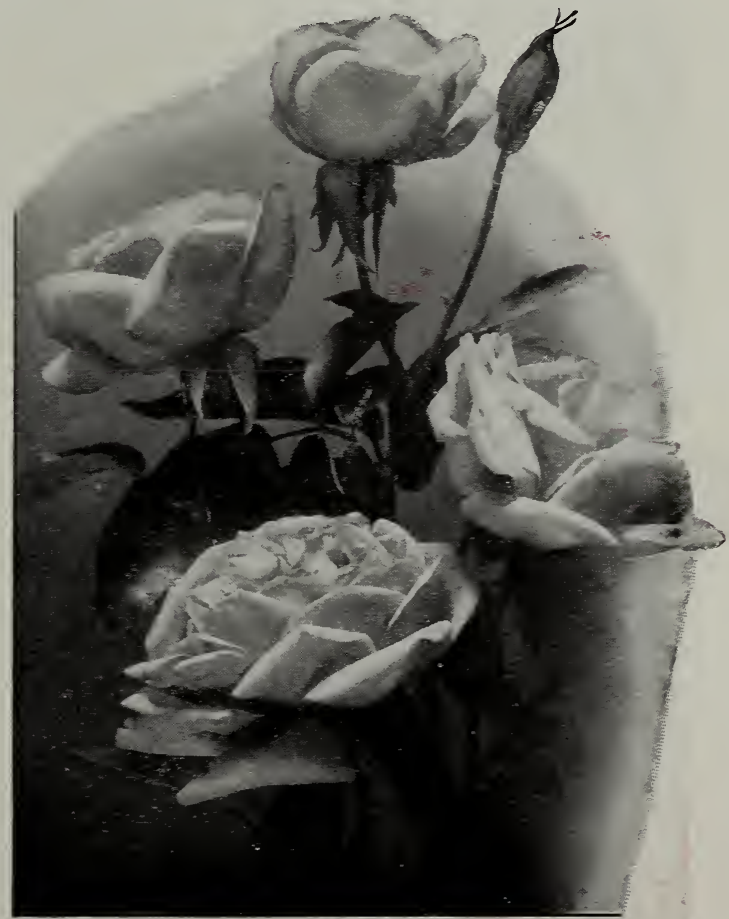

Duchesse de Brabant Rose (see page 43) 


\section{SOUTHERN Planting FACTS}

\section{Roses}

\section{Roses on Cherokee Stocks}

For many years there has been a demand for Roses that might be grown on the poorer types of soil to better advantage. After several years' testing of different varieties on different stocks, we have finally been able to produce Roses on Rose stocks which we know will grow under very exacting conditions. These Roses have been widely tested in different parts of the State by our friends among Rose-growers, and they have given satisfaction far beyond our highest expectations. List of varieties on request.

Prices on Roses on Cherokee Stocks : Large specimens, $\$ 1$ each, $\$ 9$ for $10, \$ 75$ per 100 . To get these Roses on your order, the stock must be specified.

\section{Red Roses}

Freiherr von Marschall. (T.) A stronggrowing Tea Rose, with beautiful pointed buds and flowers, varying in color from clear red to pink; an exquisite Rose. It is one of the grandest Roses in our collection, and should be planted in every Rose-garden.

James Sprunt. (C. B.) Deep cherry-red flowers, very full, double and sweet. The cut flowers keep for a remarkably long time in perfect condition. Makes a good pillar Rose, and the brilliant and beautiful flowers are to be found at all seasons.

Louis Philippe. (Beng.) Rich, velvety crimson. While not so valuable for bouquets as some varieties, it is the most showy and satisfactory dark red Rose we have for gardens and grounds. It makes a large, vigorous bush, and there is scarcely a time during the entire year when it is not covered with bright red flowers.

Papa Gontier. (T.) Outer petals red, inner ones pink. A free-flowering Rose of great merit, with beautifully formed buds and flowers. One of the best Roses in our collection.

Reine Marie Henriette. (C. T.) Cherryred, a pure shade, which does not fade or shade off into undesirable tints; large, double and beautifully formed; somewhat fragrant. This is one of the finest red climbing Roses in our collection. (See illustration, page 43.)

Virginia R. Coxe (Gruss an Teplitz). (H. T.) A bright, dazzling crimson, with beautiful buds and medium-double flowers of large size. A profuse bloomer throughout the whole season. A strong and vigorous grower.

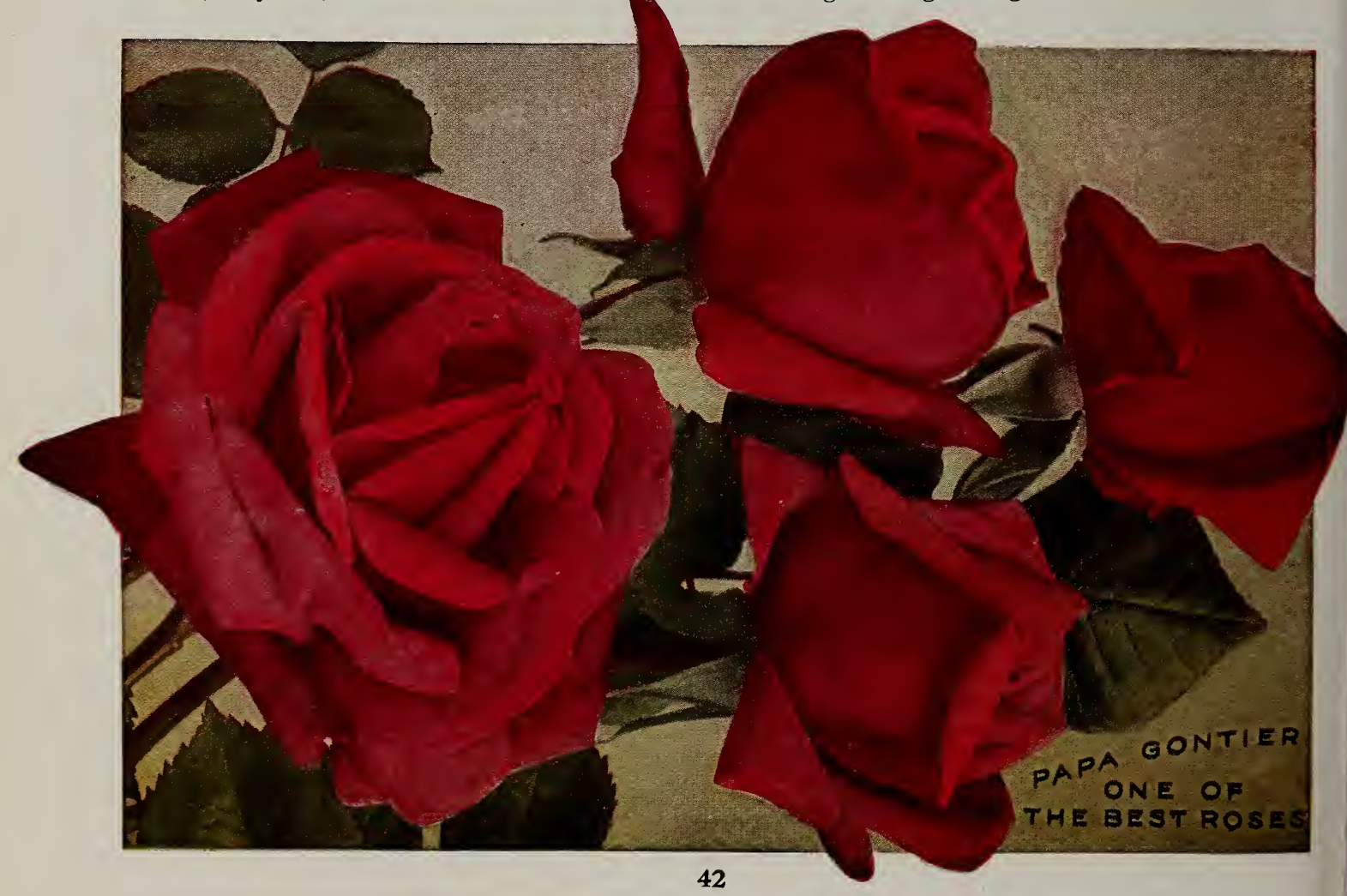




\section{SOUTHERN PLANTING FACTS}

\section{Roses}

PINK ROSES, continued

Paul Neyron. (H. P.) Strong and vigorous; pink; full-double. The largest-flowered Rose grown, often measuring 6 inches across. A very desirable variety.

Pink Maman Cochet. (T.) A free-blooming Rose, with large, pointed buds, very double; clear pink. Plant a strong grower and free bloomer, with beautiful foliage. One of the best Roses in our collection and we can strongly recommend it. A noted pink variety.

Radiance. Flowers a beautiful shade of pink, darker on the inner surface of the petals than on the margins. Buds large and very fine; a strong grower; very desirable. (See page 43.)

\section{White Roses}

Cherokee White. A high-climbing Rose, with slender, green, prickly branches; leaves usually three-parted, bright, shining, evergreen; flowers large, white, with numerous deep yellow stamens, giving a bright yellow center, showy A very handsome variety of climbing Rose, valuable not only for its flowers which appear in spring, but

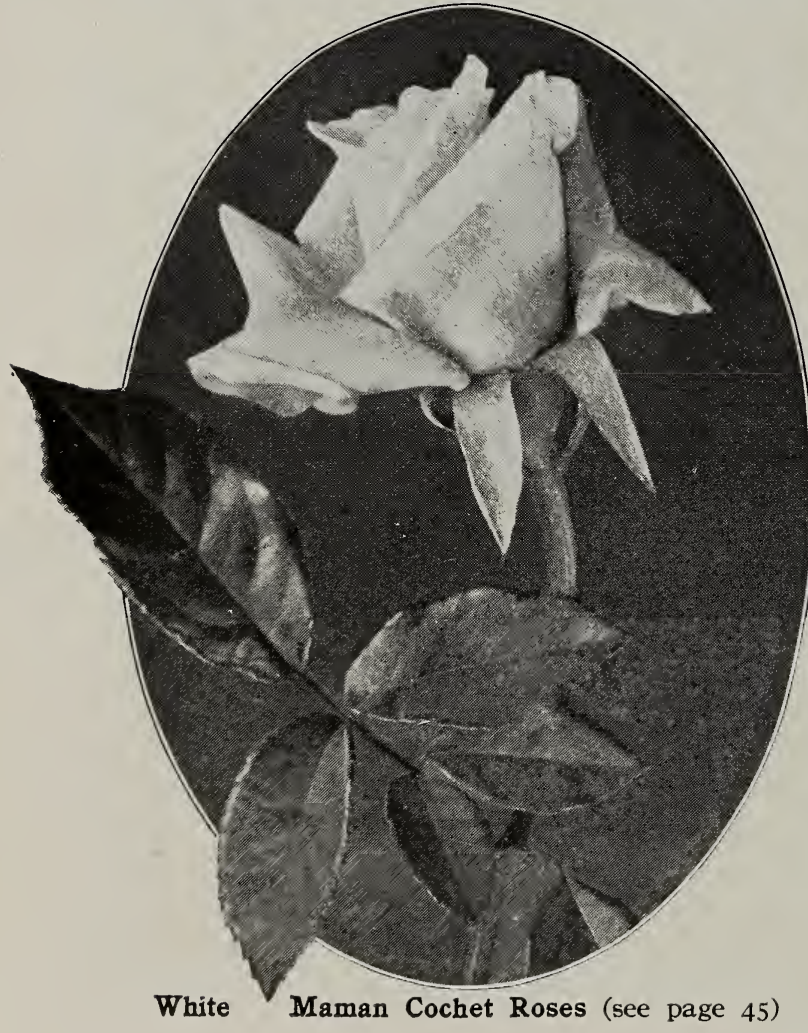

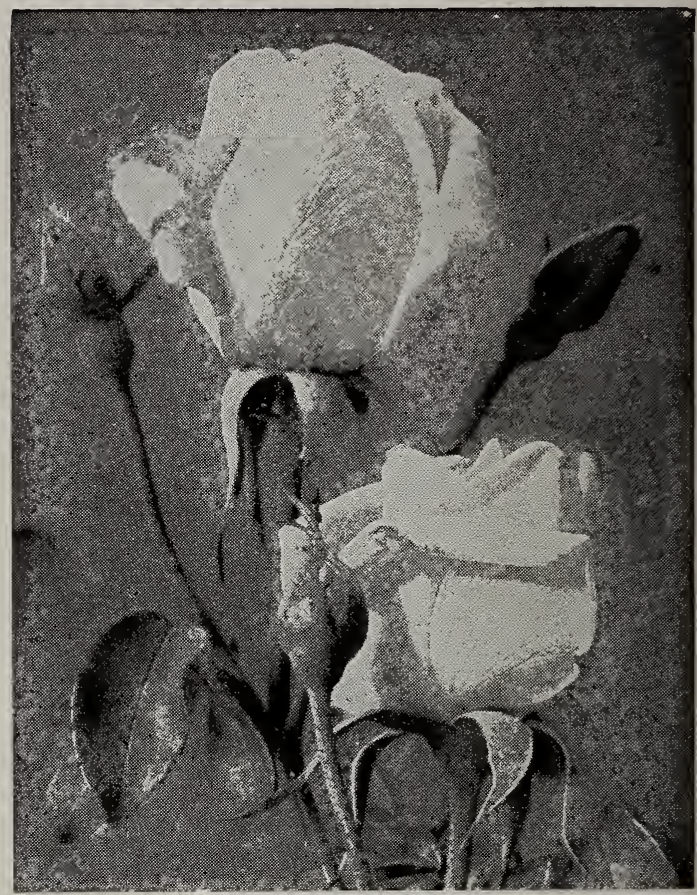

Devoniensis Roses

for its bright, evergreen foliage. Splendid for covering trellises or walls and low buildings.

Climbing Clotilde Soupert. (C. T.) White; globular buds, pink-tinted in the center; flowers in clusters of three to eight; free-blooming; a strong-growing climber.

Devoniensis. (C. T.) White, tinted with pink; with beautiful buds. This is one of the most desirable climbing sorts, and is not surpassed by any other variety in vigor of growth. It blooms profusely and flowers are always to be found.

Estelle Pradel. (C. N.) Lovely, pure white buds, flowers medium size, full and sweet; profuse bloomer. A favorite climbing Rose in the South.

Frau Karl Druschki. (H. P.) White with blooms 4 to 6 inches across; buds full, well formed; open flowers very double. A strong, vigorous grower; nearly always in bloom. We strongly recommend it.

Kaiserin Augusta Victoria. (H. T.) White with lemon center; full, pointed buds; vigorous and a good bloomer; very double. This Rose is one of the newer sorts, with handsome, bright foliage. The flowers are borne on long, straight stems. A variety of great merit. 


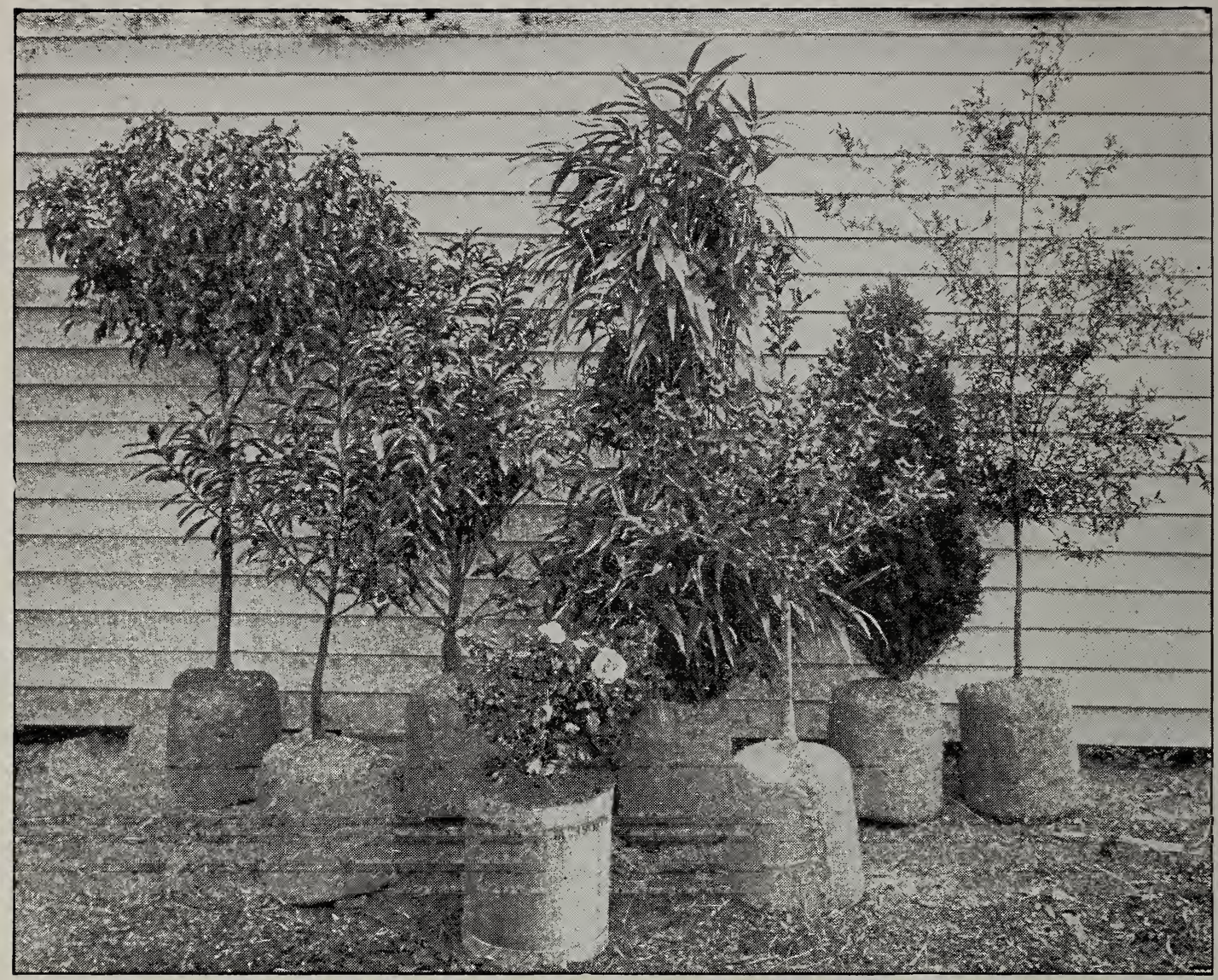

Group of Trees Balled and Burlaped for Shipping from Glen Saint Mary Nurseries

\section{Trees and Shrubs Shipped with Balls of Earth}

The method which we have perfected for handling open-ground-grown shrubs and trees of various kinds with their roots still undisturbed and surrounded by the earth in which they grew has given the best of results. Our customers are more than pleased. Hitherto it has been possible to accomplish this only when the plants were grown in heavy, compact clay soil. Our success in this new departure is one of the most important advances in the handling of trees and shrubs in years. We are now able to make shipment of trees without pruning them back, of ornamentals and roses with the flowers still on them, and ready to burst into bloom, to be transferred to your garden or grounds in their original shape and beauty. The effect is immediate, you do not have to wait for the plants to develop new heads, and repair the loss of top and branches,-in brief, we can now supply you with ready-grown shrubs and trees for a ready-made garden.

The following list of plants, which we are now able to furnish with balls of earth, is a large and comprehensive one. On special orders there are some others which we can furnish from the general lists in our catalogue.

\section{Citrus Trees:}

Oranges, Grapefruit and Kumquats.

Other Fruit Trees:

Peaches, Persimmons, Loquats, Pomegranates.
Broad-leaved Evergreens:

Gordonia, American Holly, Dahoon Holly, Magnolia grandiflora, Tea Plant, Abelia, Pink Oleander. 


\section{GLEN SAINT MARY NURSERIES}

Balled and Burlaped Trees

Shade Trees:

Scarlet Maple, Laurel Oak.

Flowering Trees:

Dogwood, Red-Bud, Crape Myrtle, Flowering

Willow, Parkinsonia.

\section{Conifers:}

Red Cedar, Cedrus Deodara, Arborvitæ of all varieties.

Flowering Shrubs:

Hydrangea, Spireas.
Bamboos:

All varieties listed on page $6 \mathrm{I}$.

Palms:

Washingtonia robusta, Washingtonia filifera, Phœnix Canariensis, Sabal Palmetto, Chamærops Fortunei.

\section{Roses:}

All varieties listed in the Rose section of this catalogue.

\section{Shipping Weights}

Our plans provide for the handling of plants in grades approximately 2 to 3 feet, 3 to 4 feet, 4 to 5 feet, and 5 to 7 feet. In some sorts larger specimens can be furnished. The larger the tree, the larger the ball of earth about its roots, and the greater the weight.

It is difficult to give exact shipping weights. Much depends upon the amount of moisture in the soil and other details over which we have no control. Trees in 2- to 3-feet grade, shrubs (Spireas, for instance) and Roses will weigh, approximately, 75 pounds each; 3 - to 4-foot trees about Ioo pounds each; 4- to 5-foot trees will weigh I50 to I75 pounds each; 3- to 4-foot Arborvitæs and 5- to 7-foot trees will weigh 200 to $25^{\circ}$ pounds each, and special grades will run 300 to $35^{\circ}$ pounds each.

\section{Planting and Care}

The plants must not be handled by picking them up by the branches, stems or trunk. Lift and move by clasping the ball of earth with the hands, or by placing planks under it. Remove from the packing-case or box by taking it apart. Do not remove the burlap about the ball of earth.

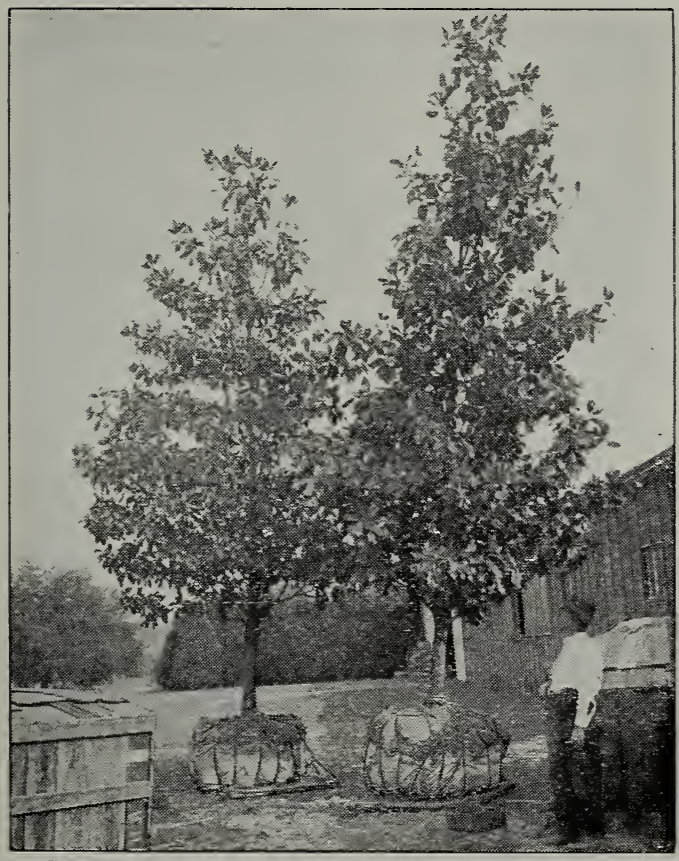

Specimen Magnolias of large size, balled for shipment
Leave it on. Dig the hole for the plant 4 or 5 inches deeper and 8 to Io inches broader than will be required to accommodate the ball of earth. Fill in the bottom of the hole with enough good, rich earth, in which a handful or two of commercial fertilizer has been mixed, to bring the top of the burlap up to the level of the surrounding earth when the plant is placed in the hole. Then fill in, with the same soil, the space between the ball of earth and the well of the hole, packing it tight. Make a basin of earth on top around the plant and fill with water, and give additional water from time to time for two or three months unless rains are frequent. Under unfavorable weather conditions it is sometimes advisable to shade the plants with burlap, but usually it is not necessary.

The leaves of Palms should remain tied together for two or three months, to prevent their being blown about, thereby loosening the plant in the ground. The strings may be loosened from time to time to accommodate the growth of leaves.

\section{Prices}

The prices on Palms are given on pages 58 , 59 and 60 . The price on specimen balled Roses is $\$ 2$ each. On the remainder of the list given above the price is four times the single rate for the grade ordered. Larger specimens quoted on request. 


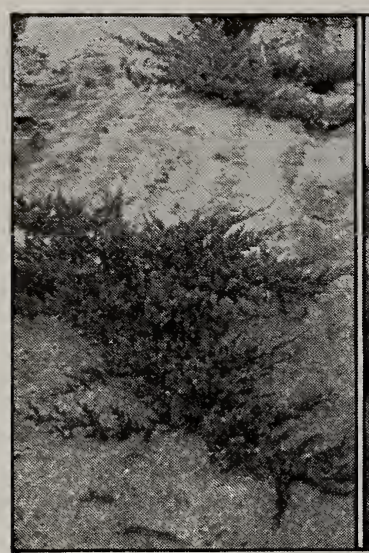

Creeping Juniper

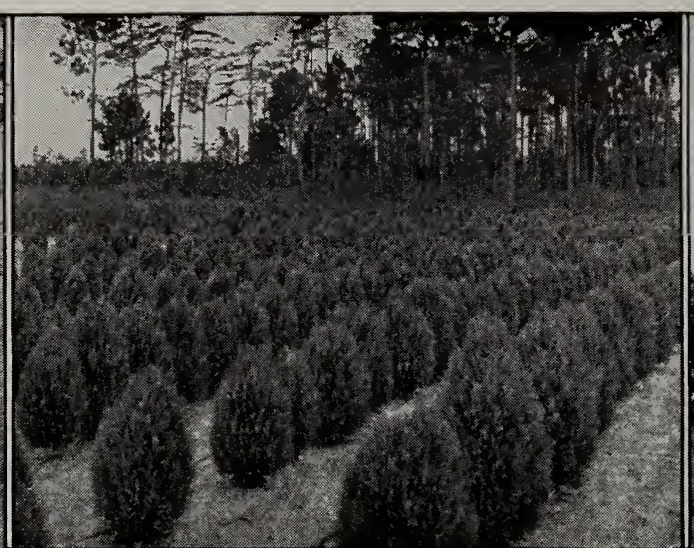

View in Arborvitæ Nursery

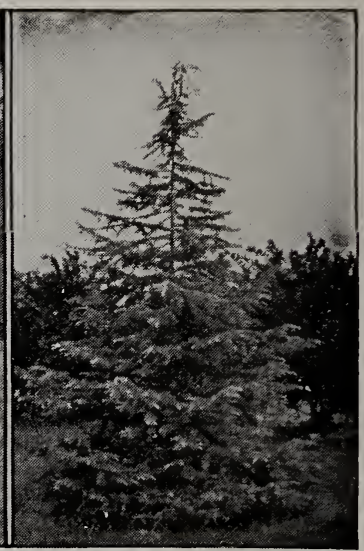

Cedrus Deodara

\section{ARBORVIT AS AND OTHER CONIFERS}

These plants make beautiful individual lawn specimens. The different colors-yellow, green, dark green and blue-green-give a striking effect when planted in masses, either when groups are made up of a single kind or of a number of different kinds. They make an excellent background for other shrubs. For hedges they are unsurpassed. In planting for a hedge, they should be given more distance than other hedge plants; 4 or 5 feet apart is not too much. As plants for porches or porch steps, they are very satisfactory. They are hardy and long-lived.

ARBORVIT $Æ$ (Thuya and Biota). Beautiful evergreen shrubs of compact, symmetrical growth; especially suited for formal plantings. The varieties we list are adapted to southern climatic and soil conditions.

Prices on Arborvitæ, Retinospora, Cephalotaxus and Juniperus. Each Per Io I00 I2 to I6 inches..... \$0 60 \$5 50 \$50 00 I 6 to 20 inches..... $75 \quad 7$ oo 65 oo 20 to 24 inches..... I oo 9 oo 80 oo 2 to 3 feet......... I 50 I 4 oo 120 oo 3 to 4 feet......... 2 50 2250 4 to 5 feet....... 5 oo 45 oo

aurea conspicua. Foliage deep yellow to golden color, often varying to green. Very compact and symmetrical. Tall and upright. 5 to 7 feet, $\$$ Io.

aurea nana. Compact, rounded head and handsome, greenish golden foliage.

Blue-Green. A handsome Biota with bluish green foliage that does not change color in winter. Very desirable. First four sizes only.

Orientalis. Compact, dark green, symmetrical. A very handsome variety. About the same shape as Aurea nana.

pyramidalis. A compact, pyramidal Biota, reaching a height of about I 5 feet. Bright green, and holds its color well. Very fine. 5 to 7 feet, \$IO.

Rosedale. Of compact, rounded, symmetrical form, with very dense head. The foliage is dark, bluish green and very handsome. 5 to 7 feet, $\$$ IO.

RETINOSPORA pisifera argentea. A dwarf, compact variety. Branches silver-tipped.
Retinospora pisifera aurea. A showy evergreen of dense growth; new shoots of a rich golden color. Very ornamental.

pisifera plumosa. With plumy dark green foliage; reaches a height of about $5_{5}$ feet.

CEDRUS Deodara (Indian Cedar). A conebearing tree introduced from the Himalayan Mountains. Of pyramidal form, reaching immense proportions. Foliage a beautiful shade of bluish green. Each

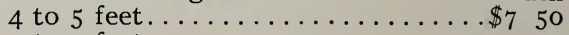
5 to 7 feet.....................

CEPHALOTAXUS pedunculata (Japanese Yew). A medium-sized tree, bushy, compact, dark glossy green. Leaves I to 2 inches long.

JUNIPERUS communis. A fine variety; spreading branches and green foliage. Each Per 1o I 2 to I6 inches..........\$0 50 $\$ 450$ I6 to 20 inches........... 60 : 5.50

oblonga. Dark green, upright in form, with slender, recurving branches. Can be pruned in any desired shape.

Sabina cupressifolia (Creeping Juniper). A Juniper of trailing or creeping habit; bluish green; very handsome. Excellent for bordering walks and for cemeteries. Each Per ro I-year...............\$o 60 \$5 50 2-year............... I oo 9 oo virginiana (Red Cedar). A dark green tree, with conical head and upright spreading branches. Grows rapidly; adapted to sunny exposures and succeeds on many different soils.

2 to 3 feet...........\$2 00 $\$$ I5 00 3 to 4 feet........... 3 oo 2500 


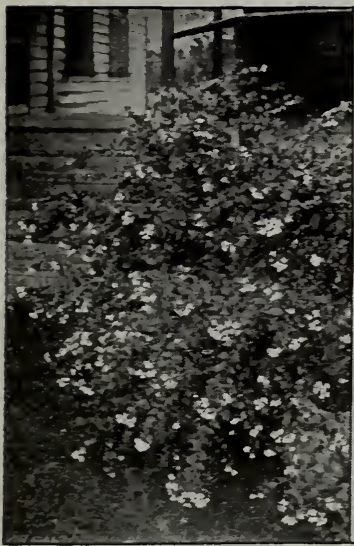

Abelia grandiflora

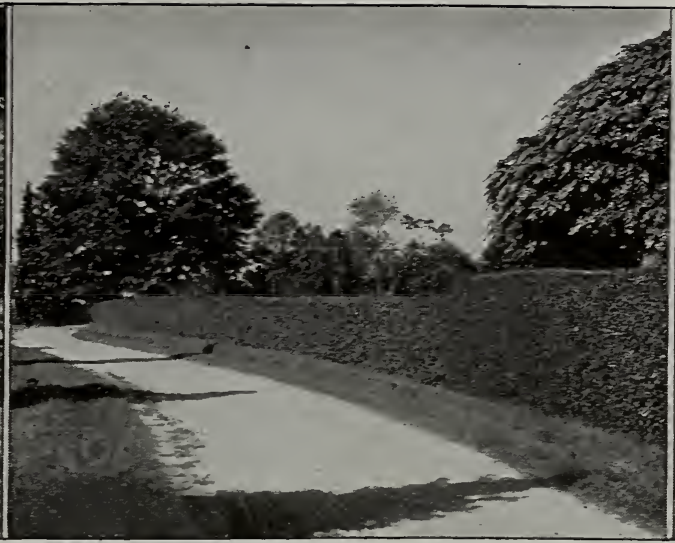

Privet Hedge

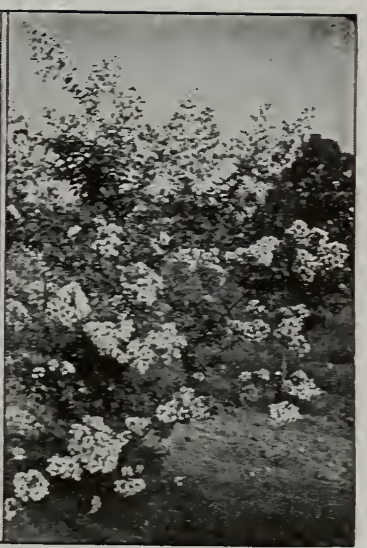

White Crape Myrtle

\section{SHRUBS AND HEDGE PLANTS}

Nothing adds so much to the beauty of the home surroundings, nothing gives so much pleasure, as a good lawn and well-placed shrubs and vines. The number which may be planted will be governed by the shape and extent of the grounds; but even the smallest lot has a place for a few. They should be planted in masses, in corners and about the buildings, always leaving a goodly proportion of open lawn. Aside from their value in beautifying the grounds, they actually increase the moneyvalue of a property. A city lot, for instance, with well-grown shade trees and shrubs, is decidedly more valuable than a piece of bare ground.

For Shrubs shipped with balls of earth, see pages 46 and 47

ABELIA grandiflora. The new hedge plant, the most satisfactory addition to the list of hedge plants in years. Can be pruned flat or rounded on top. May be planted singly or in groups, and will add a touch of beauty to the lawn all the year round. A beautiful evergreen shrub, with dark green, glossy leaves, becoming bronze-colored in winter. Flowers white, funnel-shaped, tinged with pink, delicately sweet-scented, borne in clusters from early spring until late autumn.

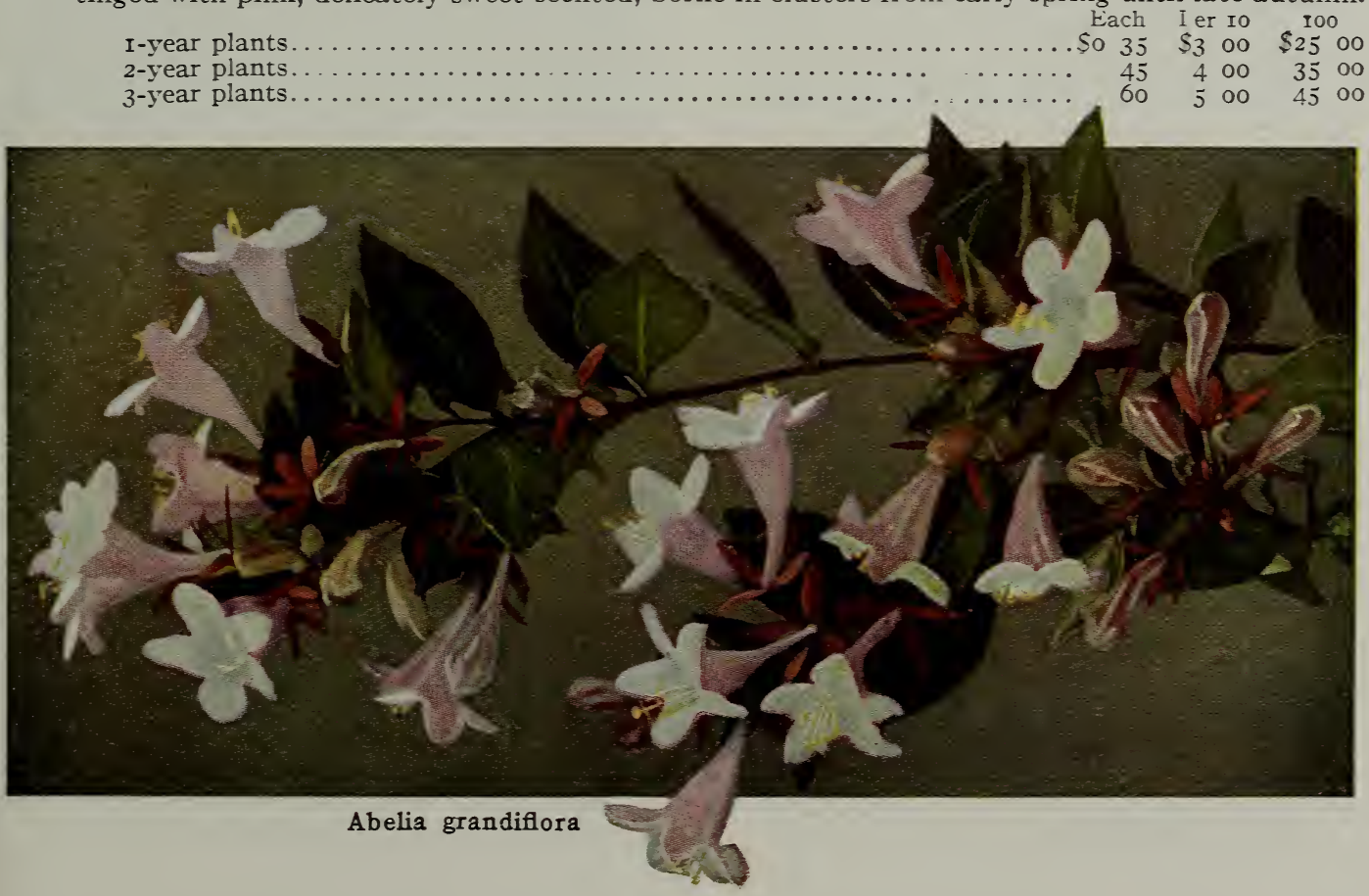


Shrubs and Hedge Plants

ACALYPHA. The Acalyphas are mediumsized shrubs of compact growth, with very showy foliage. Everything considered, they are among the most satisfactory foliage shrubs for outdoor planting in south Florida, or for indoor pot culture in the North.

$$
\begin{aligned}
& \text { Each Per ro } \\
& 21 / 2 \text {-inch pots........... \$0 } 25 \quad \$ 200 \\
& 4 \text {-inch pots............ } 35 \quad 300
\end{aligned}
$$

marginata. A large shrub, reaching a height of 6 to 8 feet; leaves green, margined with different shades of pink, red and yellow.

musaica. A smaller shrub of very compact habit; leaves beautifully marked in shades of red, green, bronze and yellow. A very satisfactory variety.

ALI.AMANDA Hendersonii. Although classed with the vines, this Allamanda may be used very satisfactorily as a shrub. (See page 64.)

ALTHÆA (Hibiscus syriacus; Rose of Sharon) This is one of our most desirable flowering shrubs. The top is rather upright and spreading. They are easily grown and produce blooms throughout a long period during summer. Each Per Io 2 to 3 feet............. \$o 50 \$4 oo 3 to 4 feet............... 60 o 500

4 to 6 feet............... $75 \quad 650$

carnea plena. Double; white, with red throat; a free bloomer.

rubra. Double; red; large; free-flowering and a very handsome shrub when in full bloom. One of the best sorts. It makes a fine hedge, and the two colors may be mixed with excellent effect.

ANDROMEDA nitida. A native evergreen shrub, with large, oblong, bright shiny leaves. Sweet-scented flowers, pinkish white, produced in early spring in the axils of the leaves. Grows from 2 to 6 feet high and is recommended for planting in shady places.

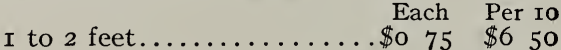

AZALEA. The Azaleas are very beautiful shrubs, producing an abundance of flowers in early spring. They are adapted to conditions from middle Florida northward, and give excellent satisfaction when planted under the proper conditions. The soil should be composed of leaf mold, muck, peat and sand, and the plants should be mulched from time to time with rotted leaves. For best results they should be planted in shady locations where they will not receive the hot rays of the summer sun. The drainage should be good and water should be furnished abundantly.
Azalea indica. Evergreen, densely branched shrubs, producing flowers of many different shades of white, scarlet, purple, crimson: salmon, and variegated colors. For mass effects they are not surpassed by any other plants.

Each Per Io Io to I2 inches......... $\mathrm{I}$ oo $\$ 900$ I 2 to I5 inches.......... I 25 II 50

lutea (Flame Azalea). A gorgeous deciduous shrub, producing immense clusters of large flowers in shades of red, orange, and vellow

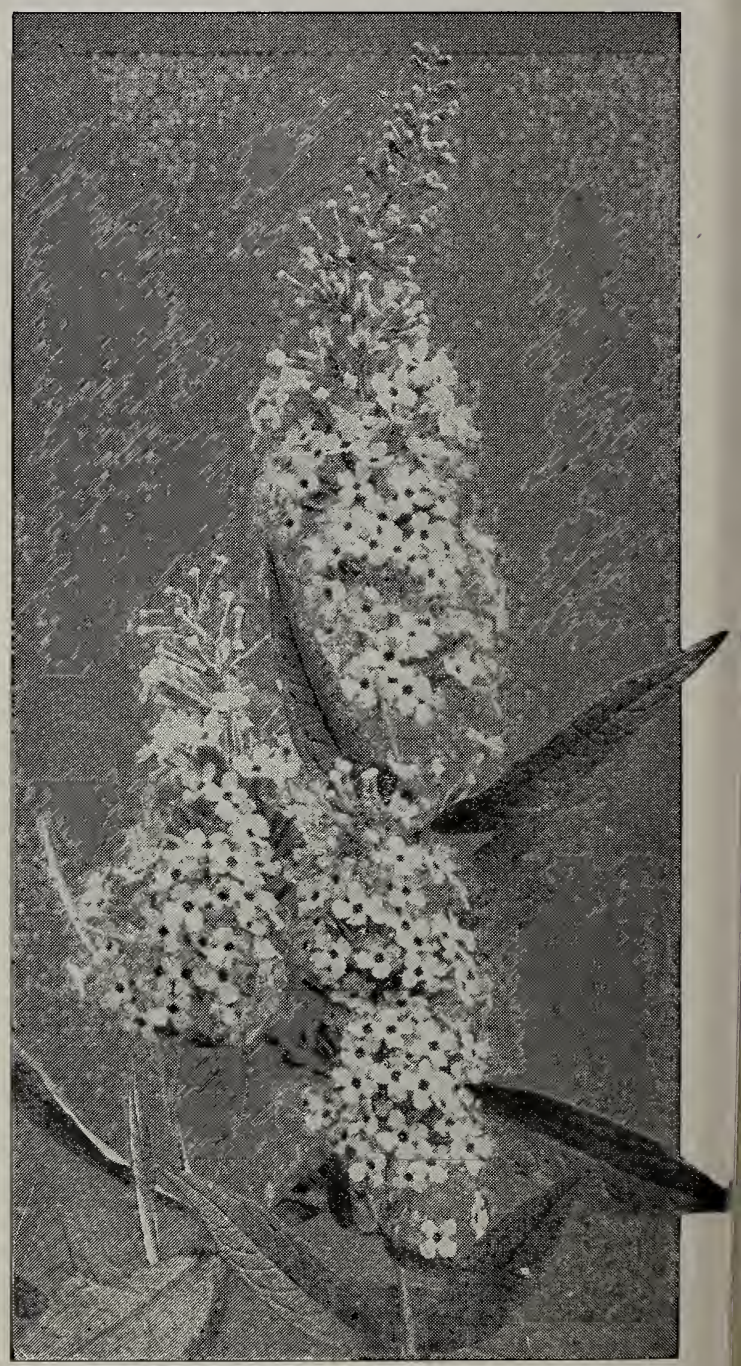

Buddleia variabilis magnifica (see page $5 \mathrm{I}$ ) 
Azalea lutea, continued

In the latitude of north Florida they bloom during April and remain in flower for weeks.

nudiflora. This native deciduous shrub is well adapted to conditions in the South. The flowers vary from deep pink to nearly white, and are sweet-scented and produced abundantly during early spring. IVe have a very fine stock of these.

Prices on A. lutea and A. nudiflora. Each Per Io Small clumps............. \$I oo $\$ 9$ oo

Larger clumps............ I 50 and up.

BOTTLE BRUSH. A beautiful evergreen shrub reaching a height of about 15 feet. Leaves narrow, dark green; flowers bright red in cylindrical brush-like spikes, opening in April and continuing in bloom several weeks. Hardy in north Florida and southward.

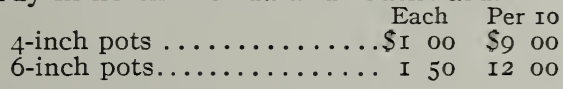

BUDDLEIA. These shrubs are amongst the most important recent introductions and have created a great deal of interest. The flowers are produced in terminal racemes and somewhat resemble lilacs in general appearance. During the summer they remain constantly in bloom and attract butterflies in great numbers. A well-grown bed of Buddleias with butterflies of many different colors flitting over them is a unique and pleasing sight. They make excellent cut-flowers. In south Florida they may be planted in autumn for winter flowering, but in other sections they should be set in late March.

Each

3 -inch pots.............. \$o 35

Field-grown plants................ 75

Lindleyana. An evergreen shrub 3 to 6 feet high, with small bright green leaves and spikes of purplish violet flowers. Splendid for mass plantings.

officinalis. A strong-growing shrub with delicate lilac-pink flowers in terminal racemes. Blooms during winter. Very fine.

variabilis magnifica (Butterfly Bush). Flowers deep violet in racemes 6 to Io inches long; much branched; leaves dark green, pointed. Very fine.

variabilis superba. This variety produces erect, arching shoots with immense spikes of lilac-colored flowers. A handsome, stronggrowing, summer-flowering shrub.

CAR YOPTERIS Mastacanthus (Blue Spiræa). A very free-flowering shrub, flowering in summer and early fall. Flowers blue, in spikes. Very effective. Each Per ro I to 2 feet.............. \$o 50 \$4 50
CESTRUM nocturnum. A shrub 6 to 9 feet high, adapted to south Florida; branches willowy, curved, producing an abundance of creamy yellow flowers, very fragrant at night.

I8 to 24 inches............ Each Per Io

2 feet and up............. 50 . 4 oo

CRAPE MYRTLE (Lagerstrcmia indica). Vigorous deciduous shrubs or small trees, reaching a height of $\mathrm{I} 5$ to 20 feet. The leaves are small, bright green and glossy. The fluwers, which appear in spring, are fringed and colored in different shades of white, purple, and scarlet. The trees, when in blossom, are covered with large panicles of bloom and remain in flower for several weeks. They are very beautiful, and make a noticeable object in any landscape. The trees are hardy, easily grown, and succeed on a wide range of soils. No other tree or shrub takes their place, and they are among the most satisfactory of the flowering shrubs for southern planting. (See page 54.) Each Per Io 100

2 to 3 feet......... \$o 50 \$4 50 \$40 oo

3 to 5 feet.......... $75 \quad 650 \quad 5000$

5 to 7 feet......... I oo 9 oo 80 oo

Special size....... 2 o0 I7 50 I50 oo

Purple. A grand sort, producing immense clusters of flowers of rich purple.

Rose. A very free-flowering Crape Myrtle, oldrose in color. A valuable addition to our list.

Scarlet. Of handsome growth; a bright, showy plant with large bunches of scarlet flowers.

White. A pure white form with large clusters of flowers; very free blooming and a showy shrub in any landscape.

HIBISCUS mutabilis (Confederate Rose). A tall-growing, shrubby Hibiscus, with large, angled and toothed leaves. Flowers very double when first opened, white or light pink, changing to deep red. Very desirable.

Rosa-sinensis. Showy evergreen shrubs, with glossy leaves and large, brightcolored flowers 4 to 5 inches across. They are amongst the most gorgeous and satisfactory shrubs that may be grown out-ofdoors in south Florida, or under glass in the North. Under suitable conditions they bloom almost continuously, and the large bright flowers are very striking. One of our best ornamental shrubs. Each Per ro 4 -inch pots.............. \$o 50 \$4 oo 6 -inch pots................ $75 \quad 650$ 8 -inch pots............ I 50

Double Pink. Flowers very large, rich pink in color. One of the handsomest. 


\section{SOUTHERN PLANTING FACTS}

\section{Shrubs and Hedge Plants}

Hibiscus Double Scarlet. A very double form. Not so strong a grower as the single varieties but a very free bloomer.

Giganteus. Single flowers of immense size, vivid crimson-scarlet in color.

Peach Blow. Flowers double, light pink with dark centers. A very beautiful variety. A vigorous grower.

Shell-Pink. A new variety, with beautiful single shell-pink flowers.

Single Pink. A single-flowered form with large flowers.

Single Salmon. A good shade of salmonyellow with red center.

Single Scarlet. Similar to the single pink but a deep, dazzling scarlet in color.

Versicolor. Flowers single, scarlet, shaded light yellow, with deep red center.

HYDRANGEA. A very ornamental group of shrubs, with showy flowers, produced in large bunches. They are excellent for planting in masses, and are very satisfactory for southern planting. Each Per ro 6 -inch pots...........\$o $75 \$ \$ 650$ Field-grown, small........ $35 \quad 3$ oo Field-grown, extra........ 75 and up.

Avalanche. Fine, large, white variety. Wellgrown specimens are very beautiful and are fine for lawn planting.

E. G. Hill. Described by introducers as pink, but the flowers with us are baby-blue. The trusses are of immense size; a fine grower and very satisfactory.

Mme. E. Mouillere. Pure white, very free flowering, one of the finest sorts.

Mousseline. Strong, upright-growing variety, producing immense clusters of blue flowers with cream-colored center.

Otaksa. Flowers deep blue, produced in large heads; very handsome; a strong, thrifty grower; very fine.

rosea. A strong, vigorous grower, resembling Otaksa in habit. Flowers bright, rosy pink. A beautiful variety.

Thomas Hogg. A handsome dwarf variety, growing in dense, compact form with large, bright green leaves. Produces large, rounded clusters of handsome white flowers.

HYPERICUM Moserianum. A dwarf, compact shrub about 2 feet high, nearly evergreen, producing an abundance of large, bright yellow flowers throughout the sum-
Hypericum Moserianum, continued mer. Fine for mass plantings. Hardy. 50 cts. each, $\$ 4$ for Io.

ILEX glabra (Inkberry). Much-branched native evergreen shrub, with bright shiny green, roundish leaves; fruit black. Well adapted for growing in clumps. Will succeed under very adverse conditions. Splendid for massing in shady locations. Height 3 to 4 feet. $\quad$ Each Per ro Small, branched.......... \$0 $35 \quad \$ 3$ oo

Larger, iranched.......... 50 and up.

LEUCOTHOE axillaris. Beautiful native evergreen shrub with spreading recurved branches and glossy dark green leaves, producing in spring numerous small white flowers in racemes. Splendid for massing in shady locations. Usually reaches a height of 2 to 3 feet.

Each Per Io

I to 2 feet............\$o 50 \$4 oo

MAGNOLIA fuscata. A very fine broad-leaved evergreen shrub suitable for culture throughout the South. Reaches a height of from Io to I2 feet. Flowers yellowish white, with banana-like fragrance. Very desirable. Io to I5 inches........... \$I 00 $\$ 9$ oo

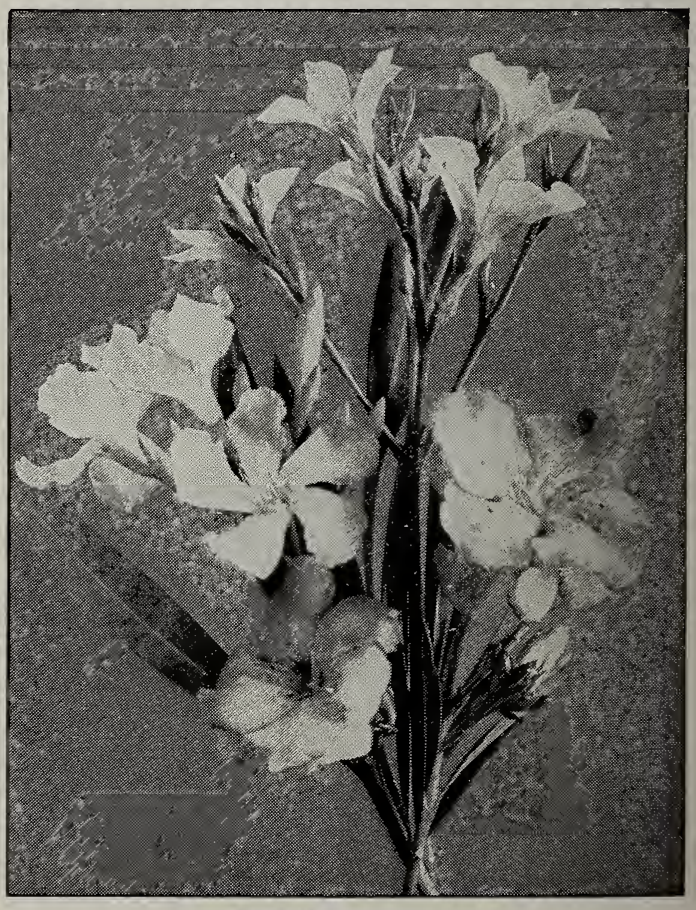

Oleander (see page 53) 


\section{GLEN SAINT MARY NURSERIES}

Shrubs and Hedge Plants

MALVAVISCUS grandiflora. A handsome freeflowering shrub, resembling a hibiscus in growth, but with drooping bright scarlet flowers. A fine addition to our list.

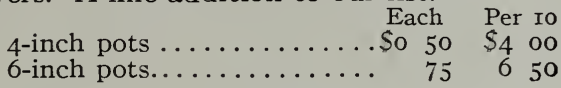

MOCK ORANGE (Philadelphus). A group of deciduous shrubs, with snowy white flowers in early spring. $\quad$ Each Per Io

I to 2 feet............... \$o 40 \$3 50

2 to 3 feet............. 50 450

3 to 4 feet................. $75 \quad 650$

4 to 6 feet.............. I oo 850

coronarius. A shrub about Io feet high, with upright branches. Flowers creamy white, produced in dense clusters of four to nine. Valuable for its very fragrant flowers.

grandiflorus. A handsome, tall-growing shrub, with narrow, oval, green leaves. The flowers are white in medium-sized clusters.

OLEA fragrans (Sweet or Tea Olive). A shrub with bright glossy foliage and small, white, sweet-scented flowers. Blooms for a long time in winter and early spring.

5 -inch pots.......... Each 00 Per Io

OLEANDER (Nerium Oleander). Very satisfactory, free-blooming evergreen shrubs of easy culture, adapted for outdoor planting in Florida and the Gulf Coast regions. The leaves are long, narrow-pointed, bright; while the flowers are very showy and produced freely. Planted singly in groups or in hedges, they are a valuable addition to any lawn.

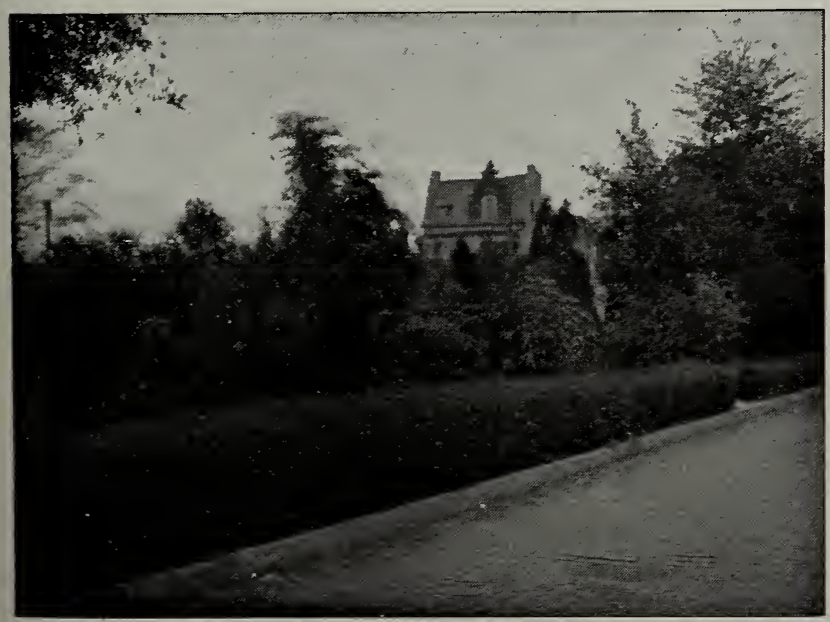

Amoor River Privet Hedge (see page 54)
Prices of Oleander: Each Per I0 4-inch pots............\$0 50 \$4 00

6 -inch pots................. 75 6 50

Field-grown, Double Pink only.............. 75 and up.

Double, Pink. A fine variety, with large, double pink flowers.

Double, Scarlet. Double-flowered; deep scarlet in color.

Double, White. Flowers double, white; produced abundantly.

Madonna grandiflora. A strong-growing variety, with white, semi-double, fragrant flowers. Very fine.

Single, Pink. A very showy, single pink variety of strong growth.

Single, White. A very free-flowering form with large masses of flowers. Very hardy.

PHYLLANTHUS. Beautiful shrubs with dark zigzag branches and thin medium-sized leaves. Very beautiful when grown singly or in clumps or hedges. Fine for south Florida. Each Per Io Io to I8 inches.......... \$o 40 \$3 50 I8 inches and up.......... $50 \quad 4$ oo

nivosus roseo-pictus. A handsome shrub with beautiful foliage in various shades of green, white, pink and red.

nivosus atropurpureus. Purple leaves and stems. A good strong grower and makes a beautiful shrub. Fine for hedges.

PITTOSPORUM. Broad-leaved evergreen shrubs with beautiful bright foliage, clustered at the ends of the twigs. Flowers in spring; can be pruned any shape. No shrubs suitable for southern planting surpass Pittosporum Tobira and its variegated form. They are both adapted for seaside planting and neither of them seem to be particular about the soil in which they are set.

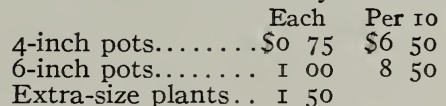

Tobira. Hardy, foliage dark green, shiny. Can be pruned to any desired shape; grows well in shade. Makes a fine hedge.

Tobira variegatum. Has light green foliage, variegated white; fine and showy.

undulatum. Leaves broad, rich deep green, and shining, with wavy margins. It may be grown as a tree or used as broad hedges. Flowers orange-scented. Half-hardy. 


\section{SOUTHERN PLANTING FACTS}

\section{Shrubs and Hedge Plants}

POINSETTIA (Euphorbia pulcherrima). The true flowers are small and yellowish, but the bracts surrounding them are very showy, bright red and gorgeous. Leaves largelobed. A fine decorative plant indoors in the North or outdoors in south Florida.

I 8 to 24 inches.

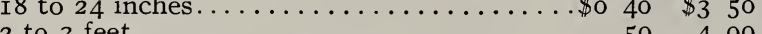

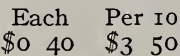

$50 \quad 4$ oo

POMEGRANATE, FLOWERING (Punica). These shrubs are among the most satisfactory for general planting. Beautiful flowers in various shades of white and pink produced all summer.

I to 2 feet

Each Per Io

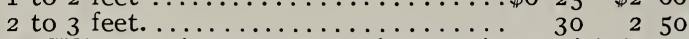

Double, White. A strong-growing variety with long, double, creamy white flowers.

Mme. Legrelle. Pink, marked with crimson veins; very full and double.

PRIVET, Amoor River (Ligustrum amurense). A densely branched variety of rapid growth, with small, evergreen leaves. The best hedge Privet known, and may be pruned in any desired form. Very ornamental when grown as an individual specimen. This is the best hedge Privet, either North or South. For hedges. set Io inches apart. Each Per Io Ioo I,, 000 I-year........... \$0 20 \$I 50 \$10 oo $\$ 80$ o0

PYRUS arbutifolia. A native deciduous shrub, producing an abundance of white flowers. A splendid shrub for early spring bloom. Each Per io

2 to 3 feet.............\$o 40 \$3 50

3 to 4 feet............. 50 450

RAPHIOLEPIS indica (Indian Hawthorn). A fine evergreen shrub, reaching a height of about 5 feet. Leaves roundish, thick, dark green. Flowers white, or pinkish white, in flat bunches, sweet-scented. Hardy.Each Per io 4-inch pots...........\$o $75 \$ \$ 6 \quad 50$ 6-inch pots ............. I oo 9 oo

SPIRÆA. The Spireas can be planted in masses, around borders or in beds, with excellent results. They bear a profusion of showy flowers in early spring, and a group planting makes a showy mass. Hardy, and well adapted to the South. Each Per io I-year plants..........\$o 50 \$4 00 2-year plants........... 6o 500 3-year plants..................... $75 \quad 6 \quad 50$

Anthony Waterer. A dense, low-growing Spirea with foliage in various shades of yellow, red, and dark green. Flowers crimson, produced freely throughout the whole summer in flat-topped bunches. Height 2 feet.

Billardii. An upright shrub, reaching a height of 5 to 6 feet, with dark brown branches and oblong leaves, grayish beneath. Flowers pink, in panicles 6 to 8 inches long. A constant summer bloomer.

cantoniensis. A compact-branching shrub, 3 to 4 feet in height, producing a dense mass of pure white flowers; very handsome.

Spiræa cantoniensis, Double. This is a very beautiful double-flowered form, corresponding in other respects with the single one.

prunifolia. A very early-flowering shrub, with pure white flowers appearing before the leaves.

Thunbergii. White, winter-flowering. The slender branches and small leaves give the plants a feathery appearance.

Vanhouttei. Branches long and arching; leaves dark green; flowers produced in clusters along the branches; hardy.

TEA PLANT (Camellia Thea). An evergreen shrub usually reaching a height, with us, of 8 to Io feet unless pruned back. Large, oval, serrate leaves; white, fragrant flowers $I / 2$ to 2 inches in diameter. Very fine. Each Per Io I to 2 feet.............. $\$ 0$ 40 $\$ 350$

VIBURNUM Tinus (Laurestinus). A very fine, broad-leaved evergreen shrub, reaching about ro feet high. Flowers fragrant, creamy white, borne freely in winter. Each Per to 4 -inch pots............\$I oo \$9 oo 6 -inch pots.............. I 25 II 50

VITEX Agnus-castus (Chaste Tree). A deciduous shrub, or much-branched small tree. Flowers lilac in racemes, opening in May.

3 to 4 feet...........\$0 50 $\$ 400$ 


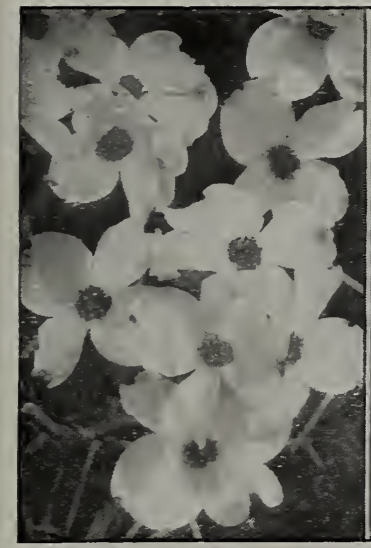

Dogwood Flowers

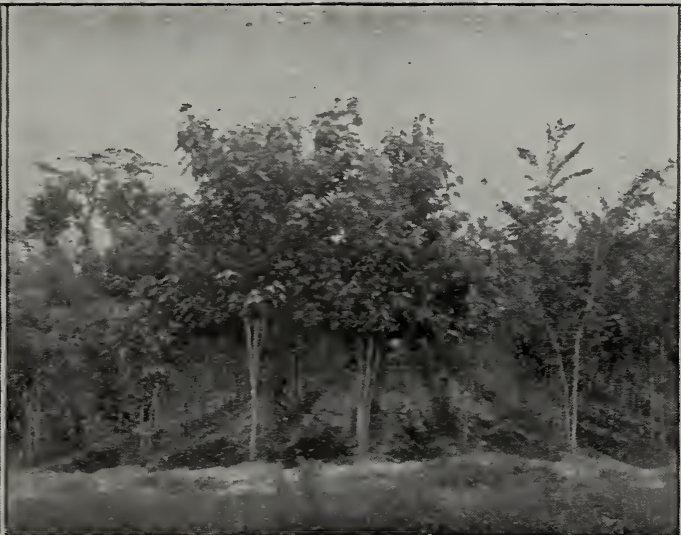

Shade Trees in Nursery

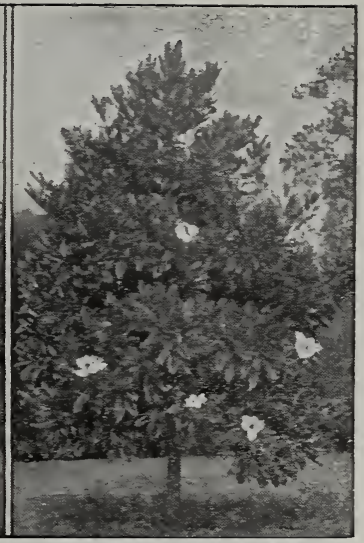

Magnolia Tree

\section{Shade Trees}

Nowhere in the country is shade so acceptable or so necessary as in the South. Whether in park or city street, country road or lawn, Shade Trees are valued not as luxuries, but as necessities for health and comfort. Nothing adds more to the home grounds, nothing so improves the appearance of town or city, as well-placed, healthy, vigorous Shade Trees.

The list of trees which is offered to our customers we can strongly recommend for planting throughout the southern states. They are carefully grown and trained. The roots are well developed and the stems are straight. They are given the same care that we give all our fruit trees. Grown in nursery rows for a number of years, our Shade Trees are vastly superior in every way to the trees which may be obtained from the woods and transplanted to the home grounds. For trees shipped with balls of earth, see pages 46 and 47 .

ALBIZZIA Julibrissin. A small tree with low, spreading, flat-topped head and finely divided, dark green, compound leaves. Flowers pink, showy, borne in large bunches at the ends of the branches. A very handsome, rapid-growing tree, suited for planting throughout the South; hardy as far north as Washington.

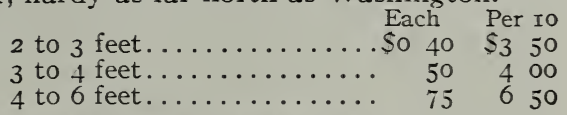

AUSTRALIAN SILK OAK (Grevillea robusta). A tree with fern-like foliage; rapid grower, well adapted to southern Florida. Most desirable evergreen tree. Each Per Io 2 to 3 feet.............. \$o 40 \$3 50 3 to 4 feet............... 50 4 oo 4 to 6 feet............... $75 \quad 6 \quad 50$

BAUHINIA purpurea. A small or shrubby tree, with large flowers in different shades of light blue to dark purple, produced during winter and spring in great profusion. A very desirable and satisfactory plant. Each Per ro I8 to 24 inches............ \$o 50 \$4 oo

CHERRY LAUREL. This fine broad-leaved evergreen is a native of the South. The leaves are large, bright, shiny. When grown to full height, it reaches 30 to 40 feet. It may be pruned in any desired shape. Makes a very fine hedge.
Prices of Cherry Laurel: Each Per Io 2 to 3 feet.............. \$o 50 \$ $\$ 400$

3 to 4 feet......................... 75 650

4 to 6 feet............... I oo 850

DOGWOOD, White (Cornus florida). A small tree, with spreading, bushy top and bright green leaves. The flowers, with their large, white bracts, appearing in spring before the leaves, make the Dogwood one of the most striking ornamental trees. The showy, bright scarlet fruit ripens in autumn. Each Per Io

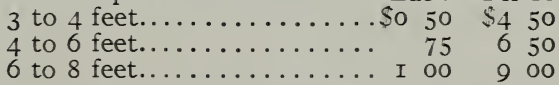

ELMS. A group of large, stately, rapid-growing trees, well suited for planting on moist soil. They are among our most satisfactory shade trees for streets or lawns. We offer varieties well adapted to the South.

\begin{tabular}{|c|c|c|c|c|}
\hline & Each & $\mathrm{Pe}$ & Io & 100 \\
\hline 3 to & So 50 & $\$ 4$ & & $\$ 400$ \\
\hline . & 60 & & 50 & 500 \\
\hline 8 & 7 & & 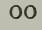 & \\
\hline to $I 0$ & I 50 & & & \\
\hline
\end{tabular}

American ( Ulmus americana). A very desirable variety, with long, gracefully curved brariches. Leaves green, lighter beneath.

Cork (Ulmus racemosa). Best adapted to the South, reaching a great height and with oblong, rounded top. Branches clothed with dark green leaves and provided with corky wings, giving the tree a unique aspect. 
EUCAL YPTUS. Rapid-growing evergreen Australian trees, many of which do splendidly in Florida. We have made a careful selection of the most desirable sorts. They are all potgrown and easily transplanted. Each Per ro I 8 to 24 inches...........\$0 $30 \quad \$ 2 \quad 50$ 2 to 3 feet.............. 40 350 3 to 4 feet.............. $50 \quad 400$ 4 to 6 feet.................. $75 \quad 650$

polyanthemos. A very ornamental variety; leaves nearly round, silvery. Thrives under a great variety of climatic conditions. Produces very fine wood.

robusta (Swamp Mahogany). A rapidgrowing tree, with spreading, reddish branches, large, oval, dark green, pointed leaves and rough, dark brown bark. Perhaps the most desirable Eucalyptus for shade.

rostrata. Grows well under a great variety of conditions. Stands extremes of heat and cold.

rudis. Very fine for street planting; withstands extremes of both heat and cold.

tereticornis. A valuable timber Eucalyptus, well adapted to trying conditions. Hardy.

viminalis. A very handsome Eucalyptus, with long pendulous branches. It stands considerable cold. Trees of this species on our grounds at Glen Saint Mary have grown splendidly and have been uninjured during the winters of the past five or six years.

FICUS elastica. In south Florida this Rubber makes a very satisfactory shade and ornamental tree. See page 68.

FLOWERING WILLOW (Chilopsis linearis). A spreading tree, reaching a height of I 5 or 20 feet. Leaves long, narrow, willow-like. Flowers lilac, striped with yellow, borne throughout most of the summer. Does well on dry land; handsome and odd. Each Per io 2 to 3 feet.............\$o 5o \$4 50 3 to 4 feet.............. 60 550

GORDONIA Lasianthus. A fine evergreen tree, reaching a height of 50 to 60 feet with large dark green, shiny leaves. Flowers white, resembling small magnolias, and borne freely on young trees. Grows satisfactorily on different types of soil. 2 to 3 feet........ \$0 50 \$4 50 \$40 oo 3 to 4 feet.......... $75 \quad 650$

4 to 6 feet......... I oo 9 oo

Extra sizes...\$2 to 4 oo

HACKBERRY (Celtis occidentalis). A large, rapid-growing tree, with spreading branches and rounded head. Leaves oblong, narrow, pointed. It grows well over a wide area.

\begin{tabular}{|c|c|c|c|c|}
\hline & ach & Per & & 100 \\
\hline 3 to 4 & 50 & $\$ 4$ & & $\$ 40 \quad 00$ \\
\hline et. . & 60 & & 50 & 5000 \\
\hline to 8 & 75 & 7 & 00 & \\
\hline to $\mathrm{IC}$ & 50 & I 2 & 50 & \\
\hline
\end{tabular}

HOLLIES. These fine evergreen trees are at home all over the South. They are not surpassed in beauty by any of our broad-leaved evergreens. We are now in position to offer three varieties. All grafted or selected fruitbearing trees. We can furnish all three species with balls of earth if desired. Each Per Io

2 to 3 feet.............\$o $75 \$ 7$ oo

3 to 4 feet............... I oo 9 oo

4 to 6 feet.............. I 50

American Holly (Ilex opaca). The Christmas Holly. Its bright green, spiny leaves and brilliant scarlet berries make it one of our handsomest evergreen shade trees. Should be severely cut back when transplanted from open ground.

Dahoon Holly (Ilex Dahoon). Budded trees of the Dahoon Holly of the South. Leaves bright and glossy, branches literally covered with bright red berries. One of the most valuable broad-leaved evergreens in our list and we strongly recommend it.

Myrtle-leaved Holly (Ilex myrtifolia). This attractive evergreen Holly has small, bright green leaves, and produces an abundance of bright red berries. One of the finest ornamentals for the lower South. Native in some parts of the southern states.

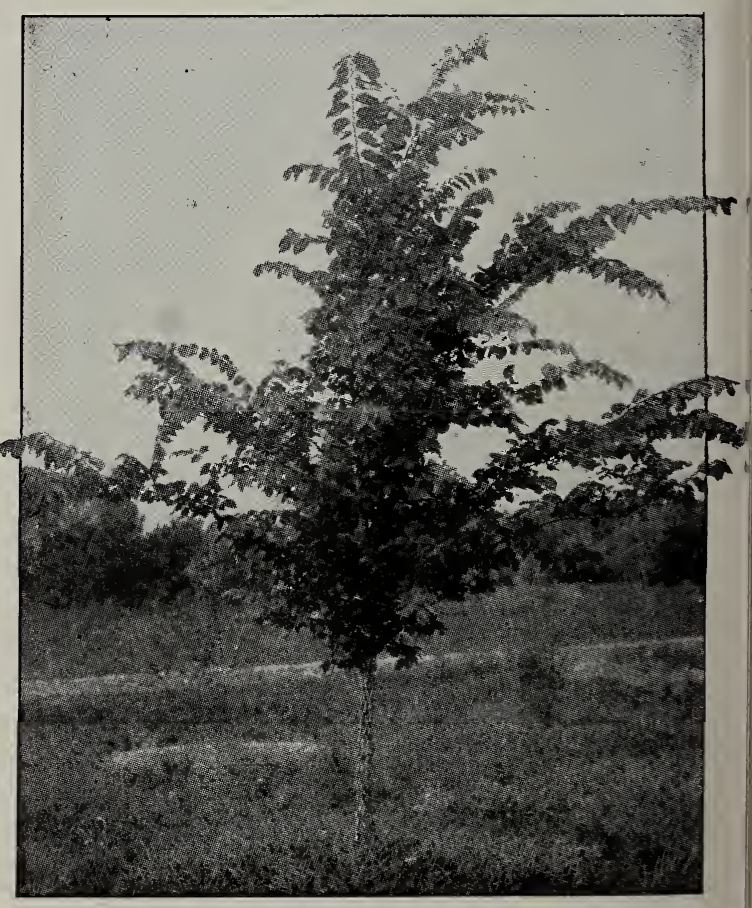

Cork Elm (see page 55) 


\section{GLEN SAINT MARY NURSERIES}

Shade Trees

MAGNOLIA grandiflora. The grandest broadleaved evergreen of the southern forests. Leaves largere, bright shining above, usually coated witl brownish hairs beneath. Flowers beautiful, large, often 8 to Io inches across, waxy white, lemon-scented and produced throughout a period of two or three months.

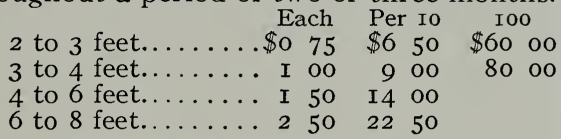

MAPLE, Scarlet (Acer rubrum). Our handsomest Maple, growing to large size, with moderately spreading branches. Leaves are three- to five-pointed, light green above, white beneath, changing to vivid shades of scarlet and gold in autumn. From very early spring until late autumn the Scarlet Maple is always attractive. Each Per 10 4 to 6 feet.............\$o $75 \$ \$ 650$

6 to 8 feet............... I 25 Io oo

8 to 1o feet............. 2 oo 15 oo

OAK (Quercus). Long-lived, of rapid growth, with graceful, rounded tops. The Oaks are among our most valuable and common shade and ornamental trees and can be grown almost anywhere. Each Per ro 2 to 3 feet............. $\$ 0 \quad 50 \quad \$ 450$ 3 to 4 feet.............. 60 550 4 to 6 feet................. $75 \quad 7$ oo 6 to 8 feet.............. I oo 850 8 to Io feet............. 2 oo I5 00 Special............ \$2.50 to 5 oo

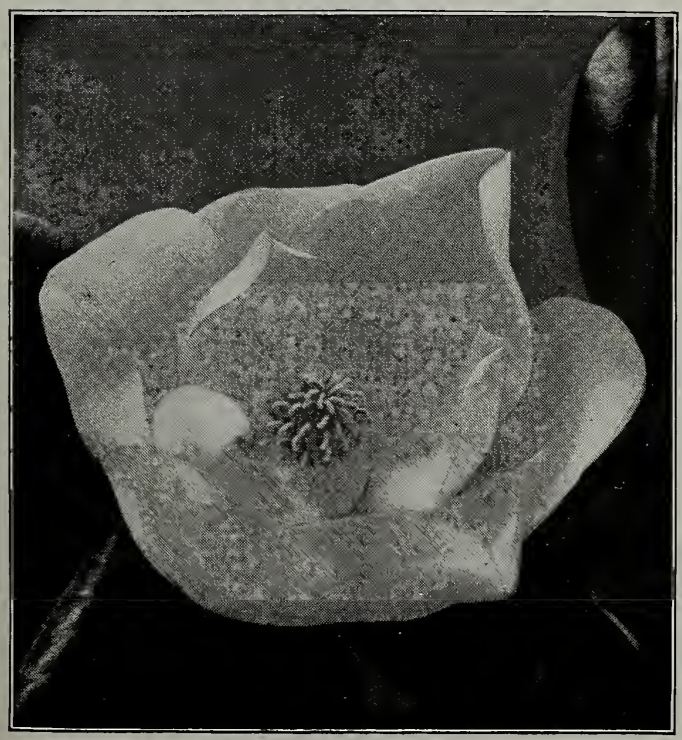

Magnolia granciiflora

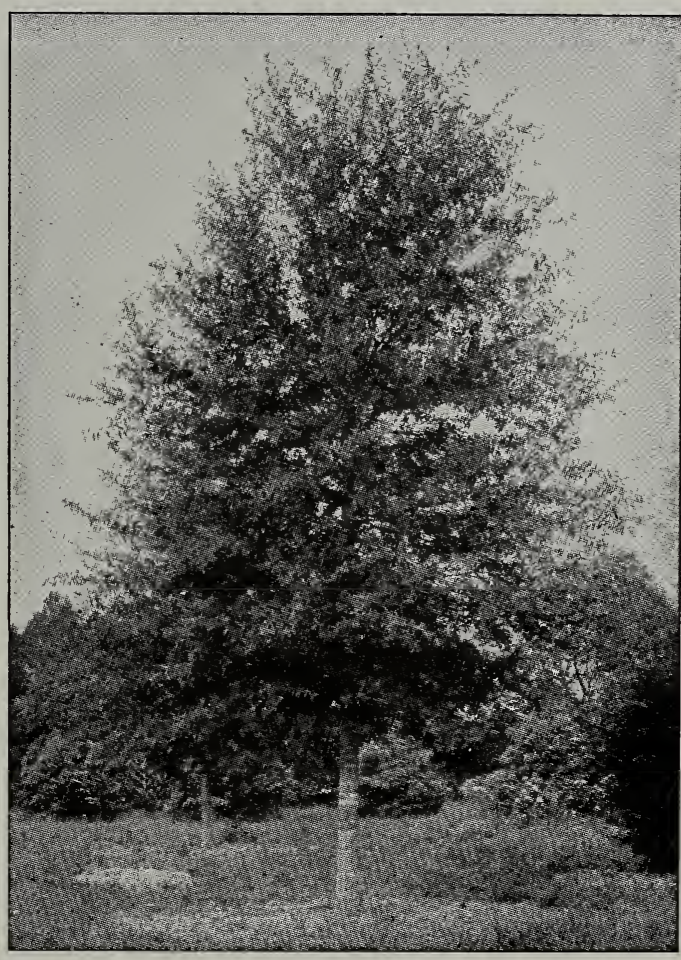

Laurel Oak

Laùrel Oak (Quercus laurifolia). A mediumor large-sized tree, with thick, rounded head and slender branches. The leaves are oblong, sometimes lobed, dark green. A handsome shade and avenue tree, and of commanding appearance as single specimens.

Live Oak. A fine long-lived evergreen tree, native of the South. Our stock of these is produced from a very fine type. 2 to 3 feet only.

PARKINSONIA aculeata (Jerusalem Thorn). A small tree with thorny branches and small, pendulous leaves. Covered in spring with a mass of yellow flowers. Each Per io 3 to 4 feet............. $\$$ o $60 \quad \$ 5$ oo 4 to 6 feet................ $75 \quad 6$ oo

Extra sizes................ I oo and up

PEGAN (Hicoria Pecan). A majestic tree, rivaling the New England elm in stateliness and grandeur. Grows well throughout the cotton states and even farther north. Valuable for its nuts and for shade. (See page 23 for prices.) 


\section{SOUTHERN PLANTING FACTS}

Shade Trees

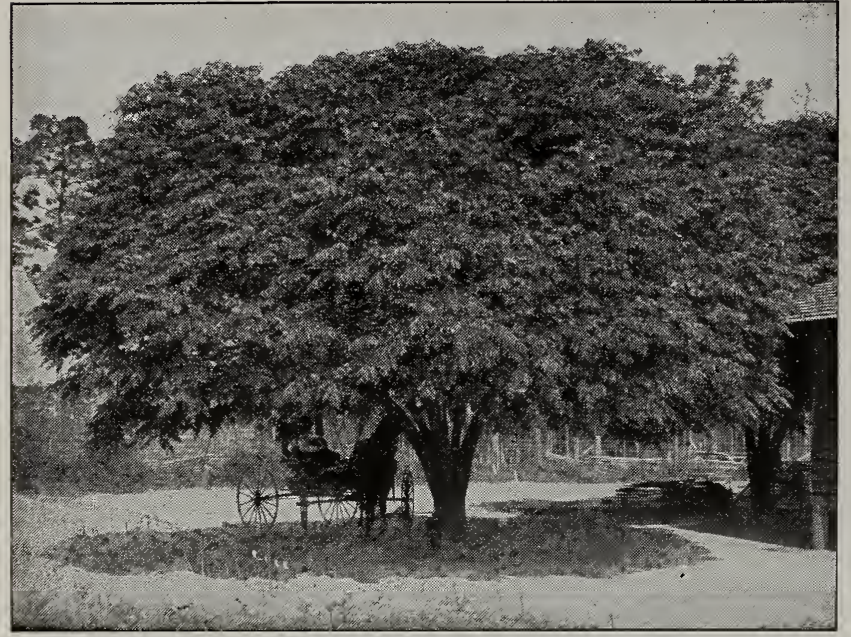

Texas Umbrella Tree

SWEET GUM (Liquidambar styraci-

$f(u a)$. Rapid-growing, native tree, with rather narrow, symmetrical, conical head. Branches often corky winged. Leaves bright green, five- to sevenpointed; in autumn brilliantly colored in shades of red and crimson. Each Per Io 3 to 4 feet.....\$o $50 \$ 400$ 4 to 6 feet...... $75 \quad 6$ oo 6 to 8 feet....... I oo 900 8 to Io feet....2 2 oo I5 00 Special sizes....

$$
\$ 2.50 \text { to } 500
$$

TEXAS UMBRELLA. A mediumsized tree, with flat, umbrellalike top. Foliage finely divided, dark green, casting a dense shade. A very desirable shade tree. Especially adapted for planting in eastern Virginia and the Carolinas. Each Per Io 3 to 4 feet......\$0 $50 \$ 450$ 4 to 6 feet...... $75 \quad 650$

POPLAR (Populus Simonii). A tall, rapidgrowing small-leaved Chinese Poplar of upright, pyramidal habit, more beautiful than Lombardy, and better adapted to the lower South. Meyer's introduction. Each Per Io 4 to 6 feet.............\$o 50 \$4 50 6 to 8 feet.............. $75 \quad 7$ oo

SYGAMORES. Stately trees with white bark, upright, spreading branches and symmetrical heads. Rapid-growing and well suited for trying locations. Where quick-growing shade trees are desired for street or yard planting, there are no better trees than the Sycamores. They are hardy, vigorous and dependable. A handsome avenue tree.

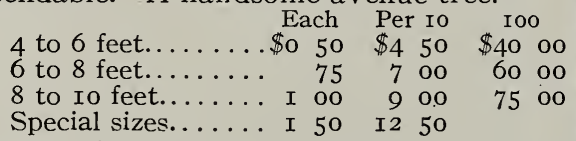

American (Platanus occidentalis). A noble tree with spreading branches and white or grayish bark. A very rapid grower.

European (Platanus orientalis). A large tree, with rounded head. Bark white; leaves large, five- to seven-lobed.

RED-BUD (Cercis canadensis). A small tree, 20 to 30 feet high, with rounded handsome leaves, producing an abundance of rosy pink flowers in early spring which make it an attractive object in any landscape. Should be planted on well-drained land. Each Per ro 2 to 3 feet............\$o 50 \$4 50 3 to 4 feet................ $75 \quad 650$ 4 to 6 feet............... I oo 9 oo 6 to 8 feet............... I 50 I 4 oo

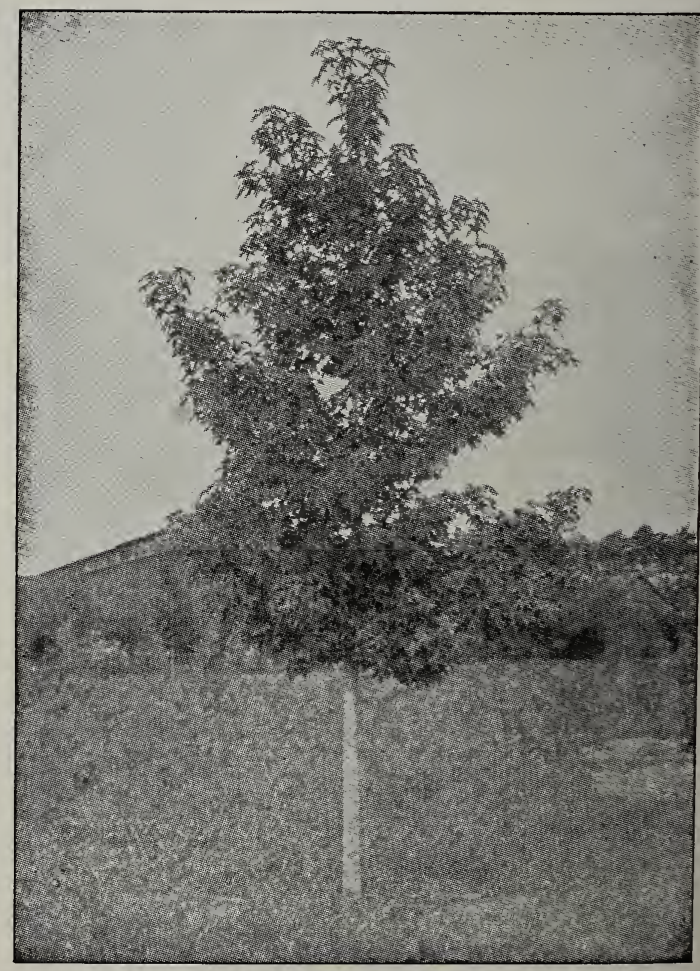

Sweet Gum

The Sweet Gum has no superior among our deciduous shade trees 


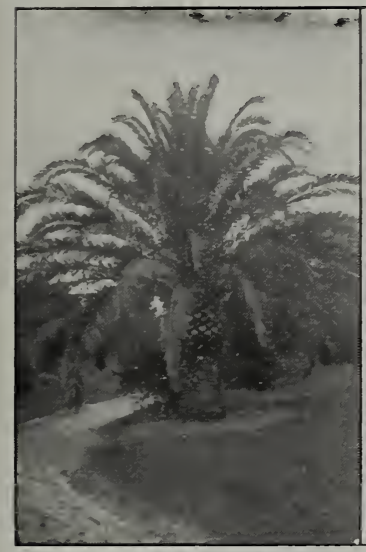

Phœnix canariensis

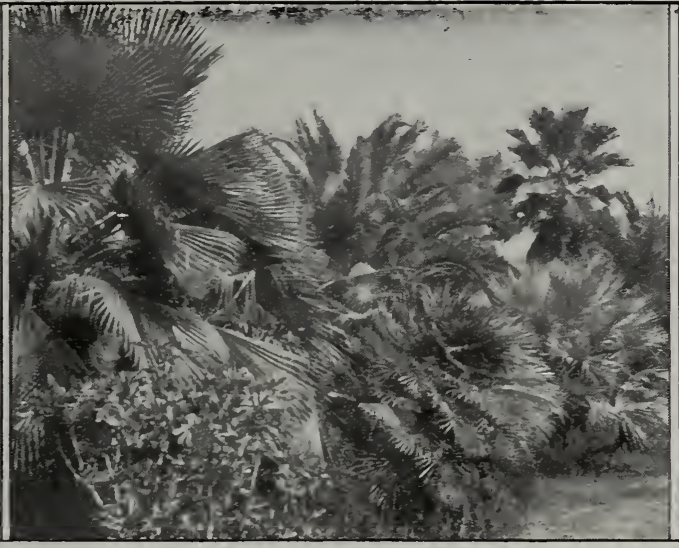

Pa'm Plarting

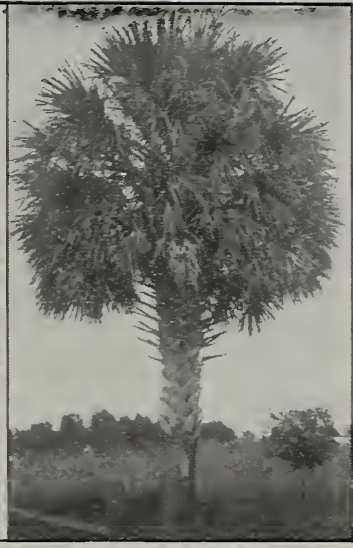

Sabal Palmetto

\section{PALMS AND GYCADS}

Palms are among the most striking plants which may be used for outdoor southern planting. Their bare, single stems and huge, arching leaves separate them from all other plants. Wherever seen, well-grown specimens always attract attention and give a decidedly tropical touch to the grounds and to the landscape. As street and shade trees, they are excellent and worthy of much more extensive use. The varieties which we offer our customers will be found most satisfactory for outdoor planting. All are pot-grown, or shipped with balls of earth, and may therefore be transplanted at any season of the year.

The place where a Palm is to be planted should be well prepared. The soil, if poor, should be thrown out, leaving a good-sized hole-30 inches square and deep is about right. Fill in with good, rich soil, carrying with it one-third well-rotted stable manure. Plant the Palm in this hole without disturbing in any way the soil that comes about its roots, pack tightly into place, tie the fronds rather closely together to keep them from being tossed about by the wind, thereby loosening the plant in the soil, and water freely. Later, the strings about the fronds should be loosened, and in ten weeks or so may be removed entirely. Fertilize liberally. Palms are gross feeders and

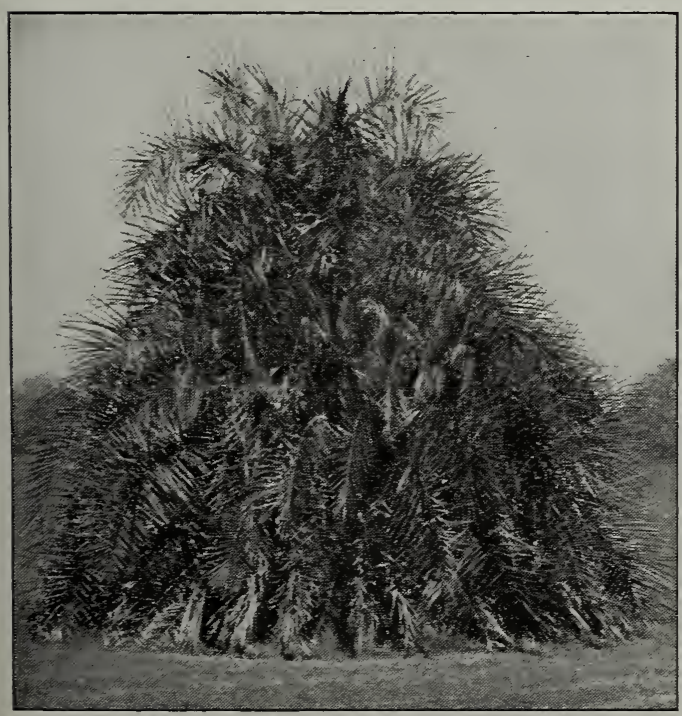

Phœnix reclinata (see page 6o) require plenty of plant-food for their best growth. Stable manure and other organic fertilizers give splendid results.

\section{HARDY PALMS AND CYCADS}

CHAM AROPS excelsa. The Chusan Fan Palm is one of the particularly hardy sorts, withstanding cold to several degrees below freezing. Reaches a height of about is feet; a valuable variety.

Each Per Io 4 -1nen pots............ \$o 75 \$6 50

6 -inch pots.............. I oo

GYCAS revoluta (Sago Palm). A Palm-like Cycad, reaching a height of 3 to 4 feet, with a handsome crown of deep green leaves curved outward from the center; very hardy; grows well out-of-doors in north Florida and along the Gulf Coast. Young plants have but a single stem; old ones are often branched. We have a particularly fine lot of these in home-grown plants of different sizes.

Each Per ro Small size ............. \$o 75 \$6 50 Medium size.............. I oo 9 oo Large and fine............ 


\section{SOUTHERn Planting facts}

Palms and Cycads

COCOS plumosa. This tree is one of the most beautiful of the Palms, adapted to south Florida and similar sections. Trunk 40 to 50 feet high, smooth, about 12 inches thick, marked with rings; leaves erect and spreading, about I 5 feet long. A fine Palm for avenue and street planting.

$$
4 \text {-inch pots..........\$0 } 75 \text { Each } \begin{array}{r}
\text { Per Io } \\
\$ 60
\end{array}
$$

OREODOXA Borinquena (Porto Rico Royal Palm). A very ornamental tall-growing Palm, with smooth trunk and plume-like foliage. Adapted to extreme south Florida, and for pot cuiture.

Each 4-inch pots, about 2 feet $\ldots \ldots \ldots . \$ 075$

PHOENIX canariensis. A stately Palm, with large trunk and large, pinnate, gracefully curved leaves. A rapid grower; very hardy and one of the best for outdoor planting in the Gulf Coast country. Each Per ro 6 -inch pots...........\$0 $75 \$ 650$ 2 to 3 feet............ 350 50 30 oo 3 to 4 feet............ 5 oo 40 oo

reclinata. A fine Palm, with slender trunk and beautiful pinnate leaves. Suckers are produced abundantly from the base, and if allowed to grow, develop into splendid clumps. Well adapted to south Florida. Each 6 -inch pots.............. \$I 00 Larger .............\$I.50 to 2 oo
Phœnix tenuis. A fine hardy Palm, similar to $P$. canariensis but with more slender trunk and smaller, arching leaves, that are light green and glaucous; a rapid grower. Very ornamental.

6 -inch pots..........\$0 $75 \$ 700$

RHAPIDOPHYLLUM hystrix (Needle Palm). This beautiful Palm is native to the southern United States from South Carolina to Florida, but rarely seen in cultivation. The trunk is short, 2 to 3 feet, covered with fiber in which are set numerous upright spines. The leaves are borne on long petioles, dark shiny green, under surface pale gray. Very beautiful and striking when planted in clumps. Each Per Io

Small size.............\$I oo \$9 00

Medium size........... 2502000

Large size............. 5 oo 45 óo

Extra size............. 8 oo 6000

SABAL glabra (Dwarf Palmetto). A native species of Palmetto with short trunk and large fan-shaped leaves almost circular in outline; dark bluish green. A very satisfactory Palm for low clumps and masses. Each Per Io 4-inch pots ...........\$o 50 \$4 50

Palmetto. This is the beautiful native Palm of the South, commonly called "Cabbage Palmetto." The trunk grows tall, the leaves are large, dark green, fan-shaped, with

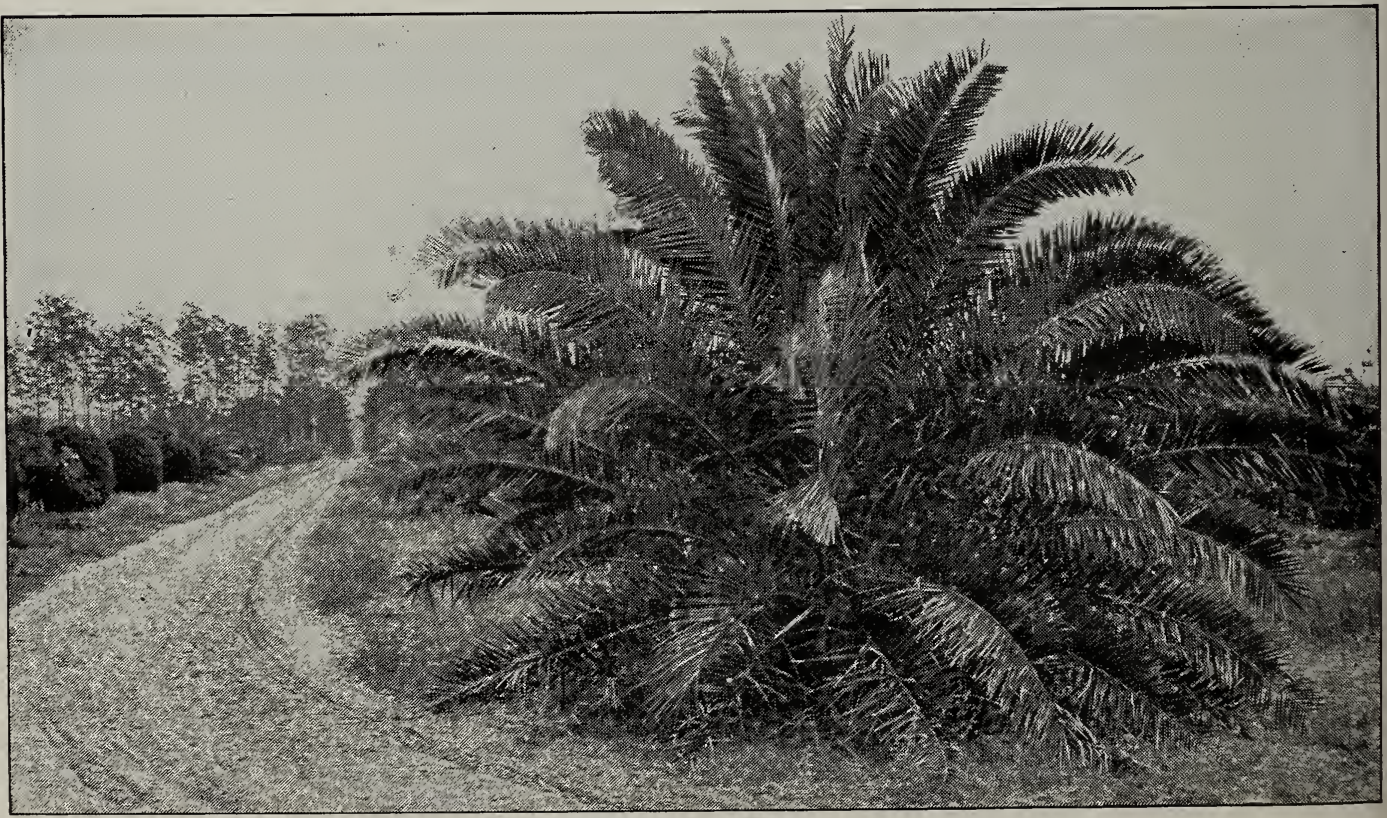

Phœnix canariensis 


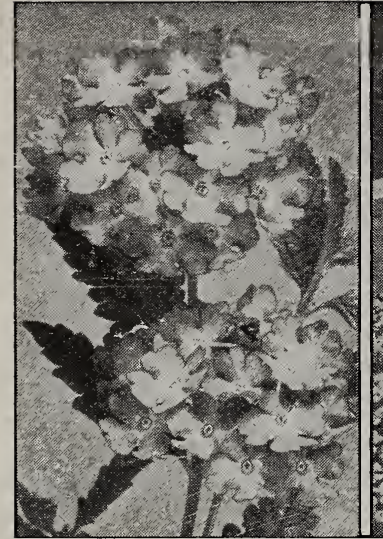

Verbena

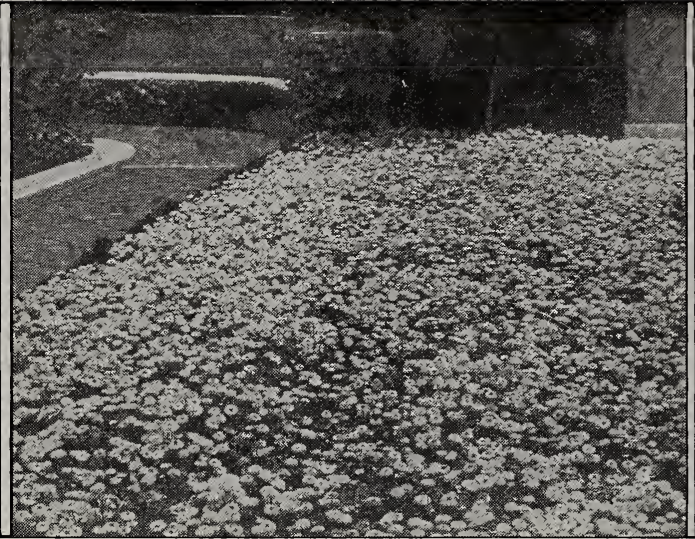

English Daisies

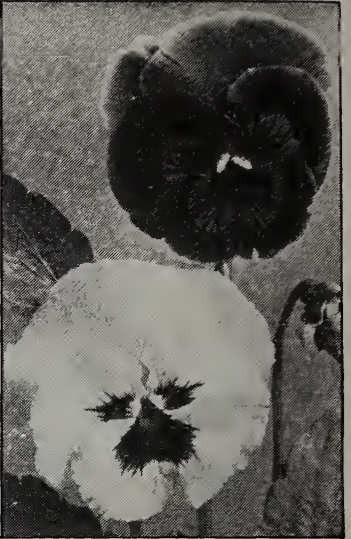

Pansies

\section{Bedding Plants}

Many bedding plants can be grown in the lower South. The most important thing is to make a proper selection of varieties to meet the soil conditions and plant them at the right season. To make this plain, it may be pointed out that violets, for instance, do well in winter, but are worthless in summer, while coleus are fine in summer and useless in winter. It is not always easy to place a plant in its best season-some are good through all the year-and a few miles farther north or south may change the seasonal conditions a great deal. The following lists have been based in the main upon such conditions as prevail in the latitude of north Florida.

The soil for plant beds should be well prepared with plenty of well-rotted stable manure and fertilizer. Water must be supplied freely, for the plants should grow vigorously if satisfactory results are to be secured.

Many of the bedding plants are fine for window- and porch-boxes.

\section{SUMMER-FLOWERING Ready March 1 to April 15}

Prices, except as otherwise listed, $\$ 1$ for 10 , $\$ 7.50$ per 100

ALTERNANTHERA. Dwarf, compact plants, good throughout the year, with bright foliage, much used for the edging of beds and for carpet bedding. We offer eight varieties in a wide range of colors-green, red, brown, etc.

BEGONIA. Very fine bedding plants, particularly adapted to shady or half-shady locations. Of easy culture and very satisfactory. We have the following varieties:

25 cts. each, $\$ 2$ for $10, \$ 15$ per 100

Gloire de Chatelaine. Dwarf, compact grower, bearing a profusion of rose-colored flowers. Hardy; satisfactory for pot culture or beds.

luminosa. Foliage reddish tinted; flowers red. Very fine.

Vernon. Pink-flowered; good bedding variety.

COREOPSIS lanceolata. Fine hardy plants, with showy bright yellow flowers, succeeding splendidly throughout the South. Blooms throughout the summer: $\$$ I for Io, $\$ 8$ per 100.
COLEUS. Rapid-growing plants, valuable for their handsome-colored foliage. Desirable for bedding out-of-doors or for growing in boxes. We can furnish an assortment of fifteen different varieties in the very finest shades of coloring. Our list embraces the following: Anna Pfeister, Beckwith Gem, Brilliancy, Chicago Bedder, Ebert, Erin, Fancy-leaved, Flambeau, John Pfeister, Little Gem, Lyons, Mrs. Rita Kirkpatrick, Prince Leopold, Setting Sun, Tapestry. Little Gem and Fancy-leaved are fine for pot and box planting.

CUPHEA. These bedding plants are well adapted for the edge of larger plantings or for carpet bedding. Easily grown and succeed under trying conditions.

ignea. Dark green leaves with elongated bright scarlet tubular flowers. Sometimes called Cigar Plant.

hyssopifolia. Shrubby, with pale lilac flowers and slender stems with small leaves.

SHASTA DAISY. A hardy perennial with large, pure white flowers, blooming throughout spring and summer. I5 cts. each, $\$ \mathrm{I} .20$ for IO. 
Bedding Plants

RUDBECKIA speciosa. A much-branched free-flowering perennial "Brown-eyed Susan." It produces a profusion of flowers throughout the summer. \$I for Io, \$8 per IOo.

STOKESIA. A beautiful plant, growing I 5 to 18 inches high, with beautiful lavender-blue flowers. Succeeds best in an open, sunny exposure. Field-grown, 25 cts. each; potgrown, I 5 cts. each.

\section{WINTER-FLOWERING}

\section{Ready November 15}

Prices, except as otherwise listed, $\$ 1$ for 10 , $\$ 7.50$ per 100

AGERATUM. One of the best winter bedding plants, giving a continuous mass of bloom throughout the season, and it also does well into the summer months. No other bedding plant surpasses it in its blue color.

CALENDULA (Marigold). A very showy, hardy annual which does well in the lower South during winter. In color the flowers vary from white to creamy white, orange, and yellow.

GERANIUM. One of the best bedding plants, with which excellent results can be secured all along the coast of Florida from Jacksonville southward, and in southern Florida for winter blooming. These should be given good drainage for best results. We can fur-
Geranium, continued nish Geraniums in single red, double red, double white, and single pink. 25 cts. each, $\$ 2$ for Io; larger plants, $50 \mathrm{c}$. and $75 \mathrm{c}$. each.

SALVIA. These fine bedding plants give excellent satisfaction, blooming throughout the winter, early spring, and on into the summer. IVe can furnish the following varieties:

azurea grandiflora. A hardy variety; lateflowering, producing spikes of light blue flowers.

farinacea. Perennial, with light blue flowers in long spikes. Grayish green foliage.

splendens (Scarlet Sage). A favorite bedding plant, producing spikes of beautiful scarlet flowers; very showy. Throughout most of Florida it will bloom during winter, in the spring and on through summer.

VERBENA. The Verbena is one of the very satisfactory plants for bedding, and blooms almost the whole year round. Very satisfactory for winter planting. Furnished mixed, in all the usual colors.

VIOLET. One of the most satisfactory winterand early spring-flowering plants, and should be planted in beds of well-prepared soil, preferably in half-shade, with the beds properly made up and plenty of moisture supplied. They will produce a wonderful profusion of bloom.

Russian. Deep blue` sweet-scented; very fine.

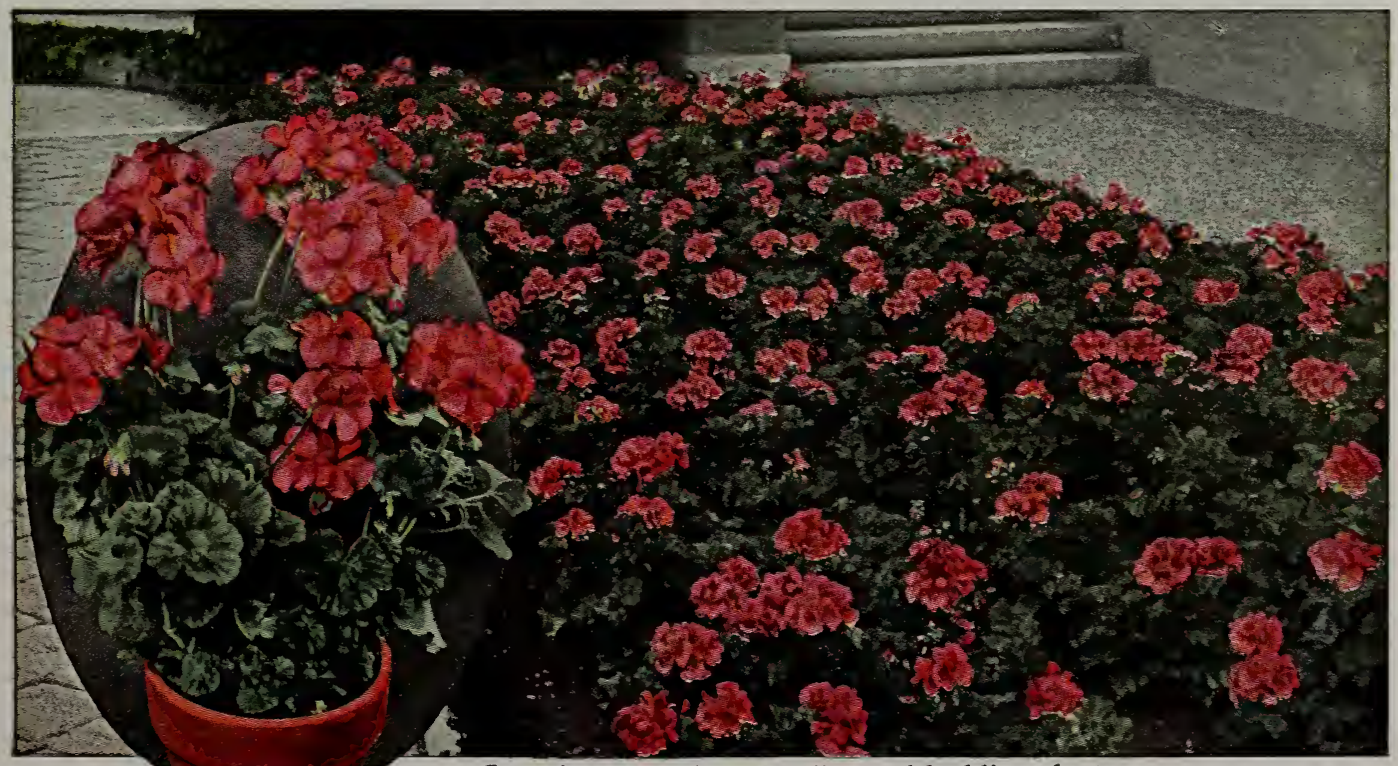

Geraniums are the best all-round bedding plants 


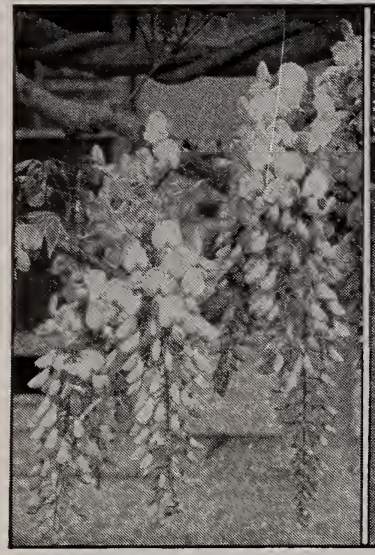

Purple Wistaria

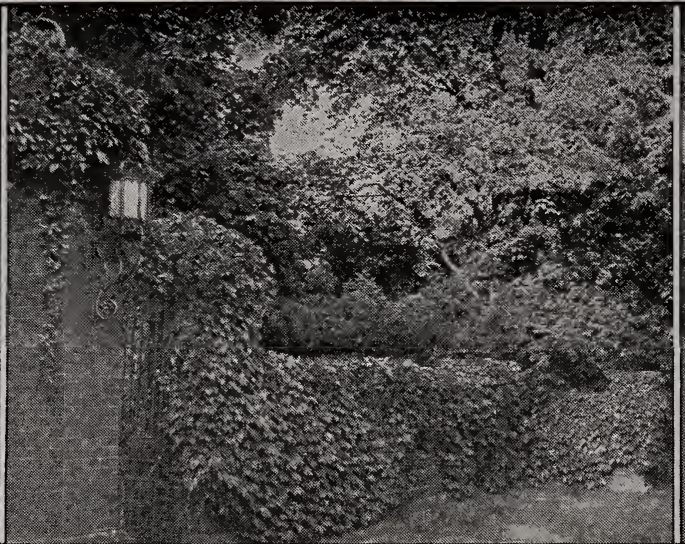

Wall Covered with Japan Ivy

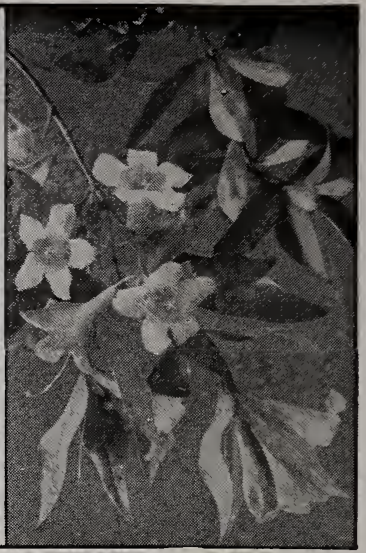

Yellow Jessamine

\section{VINES}

To add to the beauty of the home and its surroundings, Vines of different kinds are unsurpassed. If many bare, unsightly walls were covered by them, they would become things of beauty, for Vines

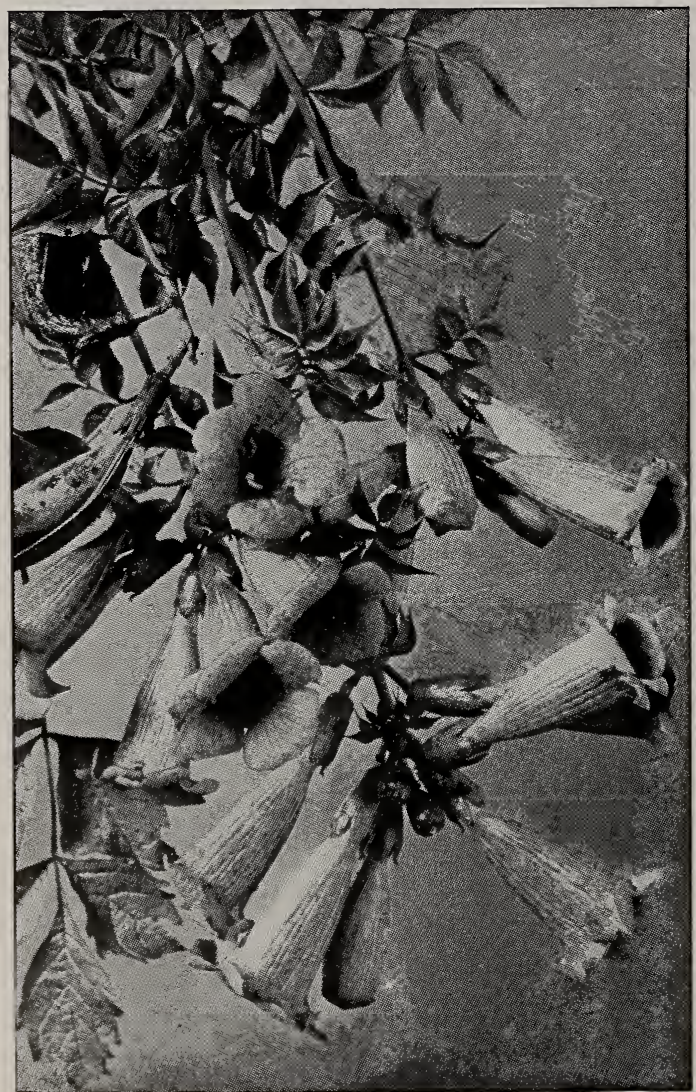

Bignonia radicans (see page 65) have the power to soften lines and cover up imperfections. Where it is desired to give an appearance of age to a building, they are unequaled.

Nothing can surpass the glory of the Wistaria, the Yellow Jessamine and Bignonia speci$o s a$, when in full bloom. The Japan Ivy and Virginia Creeper are well adapted for brick walls, or surfaces where a Vine is required to climb by fastening itself. The Honeysuckle and Trumpet Vine are splendid for covering mounds, dead trees and fences. The Yellow Jessamine, the two Honeysuckles, Allamanda and Rhyncospermum, are evergreen, and where an evergreen covering is desired they should be given preference. The Rhyncospermum, Yellow Jessamine and Trumpet Honeysuckle are sweet-scented. It should be borne in mind that the Climbing Roses are uesful for these same purposes.

For best results, the land should be well prepared, and, if planted near brick walls, the mortar and brickbats should be removed. Dig deeply and mix a fair amount of commercial fertilizer with the soil about two weeks before planting. After they are established, commercial fertilizer or stable manure may be used as a surface dressing. With good drainage, Vines require plenty of water.

PRICES ON VINES Each Per to Medium plants......... \$o 50 \$4 oo

Strong plants............. $75 \quad 650$

Extra-strong plants........ I oo

Small Ficus repens and Antigonon............. 25

ALLAMANDA Hendersonii. A strong-growing vine, with large, glossy evergreen foliage and large, trumpet-shaped, golden yellow flowers. Tender; adapted to south Florida. 
ANTIGONON leptopus (Mountain Rose). A handsome vine with heart-shaped leaves, producing large racemes of rose-pink flowers; adapted to sunny locations.

BIGNONIA. Strong-growing, free-flowering vine with beautiful trumpet-shaped flowers in different shades of yellow, orange and blue.

Chamberlaynii. A hardy evergreen vine, producing an abundance of bright yellow flowers in early spring.

radicans (Trumpet Vine). Leaves compound, deciduous, dark green; flowers brilliant orange, produced throughout the summer. Very hardy. (See page 63.)

speciosa. A hardy evergreen vine, with glossy leaves. Flower clusters large; purple.

venusta. One of the strongest-growing vines, climbing to a great height; evergreen with bright, glossy foliage; flowers borne in great profusion, tubular, bright reddish orange; very showy. Tender; adapted to south Florida.

BOUGAINVILLEA glabra Sanderiana. A showy vine, bearing large masses of purple flowers. A strong grower and reaches a great height. While tender, with care it does quite well even in north Florida. It may be grown as a shrub, with care in pruning.

ENGLISH IVY (Hedera helix). The wellknown English Ivy. An excellent covering for walls and tree trunks. In Florida succeeds best in shaded locations or northern exposures.

FICUS repens (Climbing Fig). No other vine is quite so satisfactory for covering foundations of buildings or wall. Small-leaved evergreen vine; quite hardy.

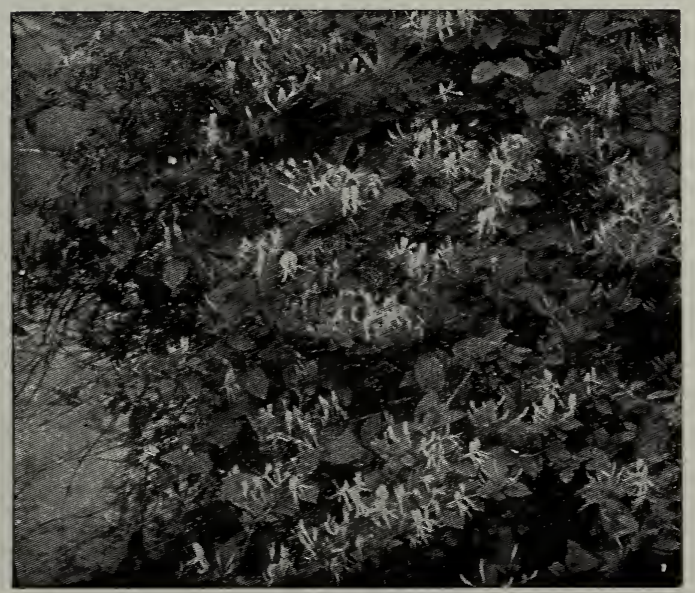

White Honeysuckle
HONEYSUCKLE (Lonicera). Rapid-growing vines, with handsome flowers. Make a dense covering adapted for porches, trellises, and for hiding unsightly places.

Trumpet (Lonicera sempervirens). A beautiful, strong-growing vine, with oval leaves, bluish green in color. Flowers showy, scarlet on the outside, yellow within, large and produced nearly the whole year with us. Even in winter it continues in bloom.

White (Lonicera japonica). A rapid-growing vine, stems slender, leaves dark green. Flowers sweet-scented, white, changing to yellow. Produces a dense covering.

JAPAN IVY (Ampelopsis Veitchii). A beautiful, rapid-growing vine, with three-lobed or threeparted, dark, glossy green leaves. A very beautiful vine, especially adapted for covering brick and stone walls. (See page 63.)

JASMINUM gracillimum. An evergreen vine or scrambling shrub, with beautiful green foliage and showy, white, star-shaped flowers. It may also be grown in shrub form. Quite hardy and a satisfactory vine.

MUSCADINE GRAPES. These make splendid vines for arbors and similar places. (See page 32.)

ROSES. See pages 37 to 44 for best climbing varieties.

RHYNCOSPERMUM (Rhyncospermum jasminoides). Leaves rounded, rather small, thick, shiny; flowers produced freely, white, star-shaped, small, very fragrant. A very desirable vine. Hardy and evergreen.

VIRGINIA CREEPER (Ampelopsis quinquefolia). A hardy, rapid-growing, clinging vine; leaves deciduous, dark green, fiveparted, gorgeously colored in fall. A splendid vine for walls, arbors, and porches.

WISTARIA (Wistaria chinensis). Magnificent, strong-growing, woody vines, hardy throughout the country. Leaves deciduous; the flowers are borne in large, pointed clusters, with or before the leaves in spring. Wistarias make handsome specimens when staked and grown as trees.

Purple. A very strong-growing sort, producing large panicles of purple flowers. (See page 63.)

White. A very fine variety, with large clusters of delicately scented white flowers.

YELLOW JESSAMINE (Gelsemium sempervirens). A slender, rapid-growing evergreen vine. Flowers yellow, fragrant, produced in profusion during the spring months. (See page 63.) 


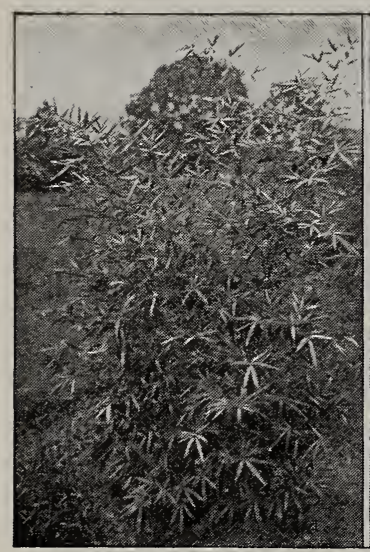

Bambusa aurea

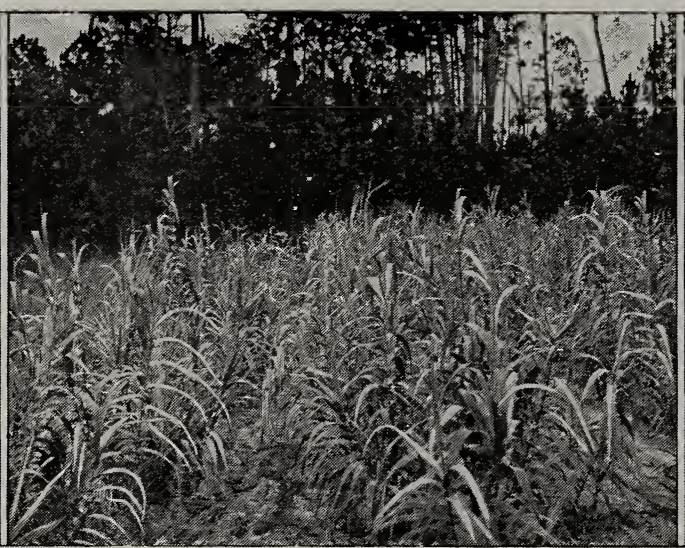

Planting of Ornamental Grasses

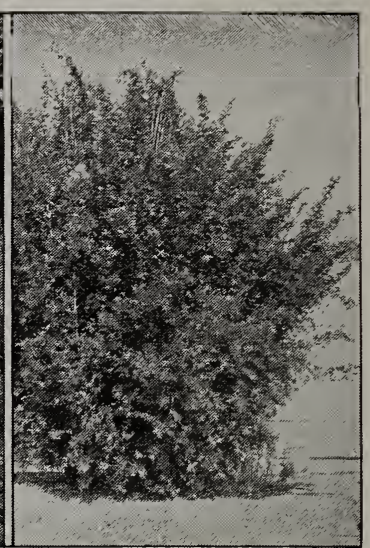

Bambusa argentea

\section{BAMBOOS, GRASSES, SEDGES}

Among ornamental plants, none are more important than the Bamboos and taller-growing Grasses. The long, willowy canes and fine foliage give a delicate, pleasing effect. Under suitable climatic conditions they will grow on very poor soil, particularly if well supplied with plant-food and water. Either commercial fertilizer or stable manure may be used to good advantage. The large-growing varieties of Bamboos make excellent windbreaks, and are also valuable for tall hedges and as screens for unsightly buildings or other objects. They are excellent for planting in ditches, canals and water-courses. In such locations they grow to perfection.

Those listed below have been carefully tested for hardiness and general beauty. They will withstand temperatures of twelve to fifteen degrees above zero without injury, and should be more generally used throughout the South. Nothing else takes their place, and, where tropical effects are desired, Bamboos are among the most satisfactory plants to use. They may be planted either in single clumps or in masses, but must be allowed a goodly amount of space.

PRICES ON BAMBOOS, PAMPAS GRASS, AND HARDY PLUME GRASS.

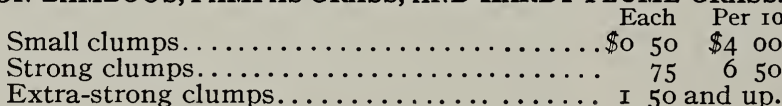

\section{BAMBOOS}

ARUNDINARIA falcata. A graceful Bamboo, reaching a height of Io to 12 feet. Grows in dense clumps; leaves fern-like. Hardy.

nitida. Dwarf, compact-growing Bamboo, with beautiful foliage, reaching a height of 3 to 4 feet, with rounded top.

BAMBUSA argentea. This very desirable variety reaches a height of 30 to 40 feet, with graceful, spreading top. Hardy.

argentea striata. This variety is the same as Argentea, except that the leaves are beautifully striped green and white. A strong grower. Hardy.

aurea. Stems yellow, reaching a height of Io to I2 feet. Rootstocks spreading; branches open and spreading. Hardy.

Metake. A handsome, broad-leaved Bamboo, reaching a height of 10 feet. Grows in large, dense masses; ornamental. Hardy.

verticillata. Canes striped yellow; 15 to 20 feet. Makes fine clumps; very hardy.

violescens. A low-growing Bamboo with dark, muchbranched stems; rootstocks spreading. Hardy.

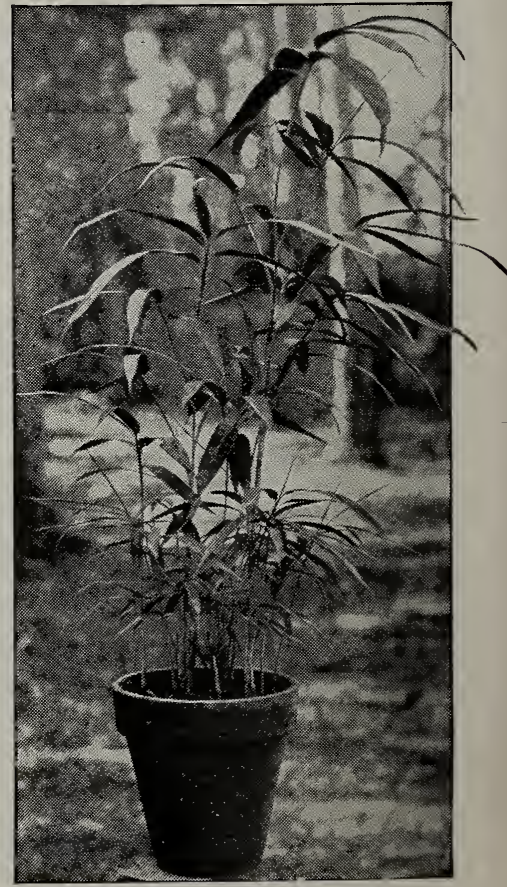

Bambusa Metake 
Bamboos, Grasses, Sedges

\section{ORNAMENTAL GRASSES AND SEDGES}

These are very valuable plants for many purposes-as individual specimens, for grouping, for the borders of walks or edges of beds of flowering plants of various sorts.

Prices on Ornamental Grasses and Sedges not priced with Bamboos. Medium clumps.......... \$o 35 \$3 oo Strong clumps............. $50 \quad 4$ oo

ERAGROSTIS chloromella (Blue Plume Grass). A handsome Grass with narrow, bluish green foliage. Leaves long, arching, and make a solid mat. Excellent for edging.

curvulea (Green Plume Grass). Foliage green, retaining its color the year round. Similar in habit to Eragrostis chloromella and very useful for the same purposes.

ERIANTHUS Ravennæ (Hardy Plume Grass). A hardy grass, reaching a height of ro or I2 feet, with numerous flower-spikes. It resembles Pampas Grass.

EULALIA gracillima univittata (Japan Rush Grass). A Grass of graceful habit, with narrow leaves, bright green in color, and silvery midribs. Height 5 to 6 feet.

PAMPAS GRASS (Gynerium argenteum). A large, strong-growing Grass producing splendid clumps 6 to 8 feet high, with white, plume-like flowers. A valuable ornamental Grass. May be used as a screen against walls or unsightly objects.

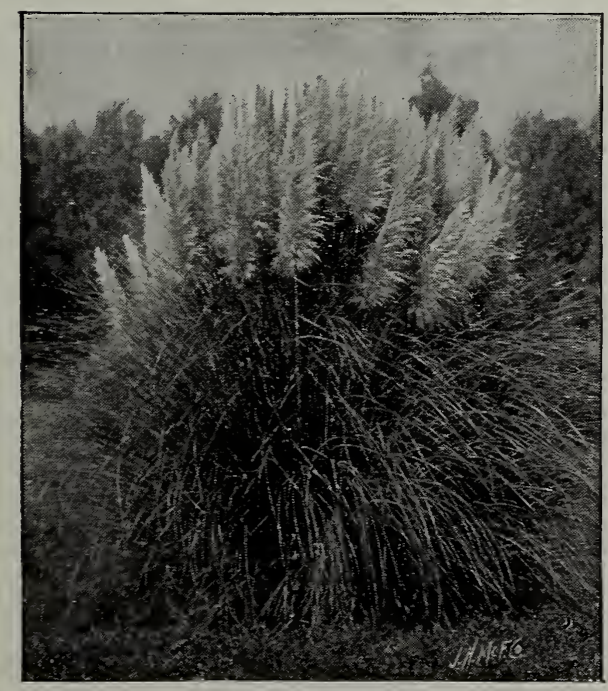

Pampas Grass
PANICUM palmifolium (Palm Grass). A vigorous-growing Grass with broad, handsome foliage; makes a splendid pot plant and is also good for growing out-of-doors. Leaves 4 or 5 inches broad; very ornamental.

PENNISETUM japonicum. This Grass reaches a height of about 4 feet, with narrow, bright green foliage and flower-heads tinged with purplish bronze.

longistylum (White Fountain Grass). A fine, dwarf Grass with broad feathery spikes 2 to 4 inches long. One of the best Grasses for bedding purposes.

Rupelianum (Purple Fountain Grass). An ornamental Grass with purplish plumes and graceful green foliage. Very fine for edging beds of cannas or other tall-growing plants.

\section{Sedges}

CYPERUS alternifolius. An attractive Sedge, growing in clumps, and reaching a height of 18 to 36 inches; leaves drooping, spreading in umbel-like clusters. A good plant for pot culture and for planting out-of-doors in Florida.

ISOLEPIS gracilis. Stems of this Sedge are 6 to Io inches long, slender, round, erect at first, afterwards drooping. Easily cultivated; makes a good pot plant and very fine for window- or porch-boxes.

\section{LAWN GRASSES}

In the lower South lawns are not so easily made as in some other parts of the country. The Grasses are started not from seed but by setting out parts of the plants, either stems or rooted stems. While the lawn is young, considerable attention is required to keep it free from weeds. The Grasses which succeed farther north are not suitable, and the two grasses commonly used are the following.

Per 100 cuttings, 75 cts.; per bushel, $\$ 1.50$

BERMUDA. A fine-leaved Grass which, with proper attention, makes a very dense mat; not adapted to shady places.

ST. AUGUSTINE. A broad-leaved Grass which makes a coarse sward, but with care and attention makes a very satisfactory lawn. This Grass is unsurpassed for growing under trees or in other shady locations. 


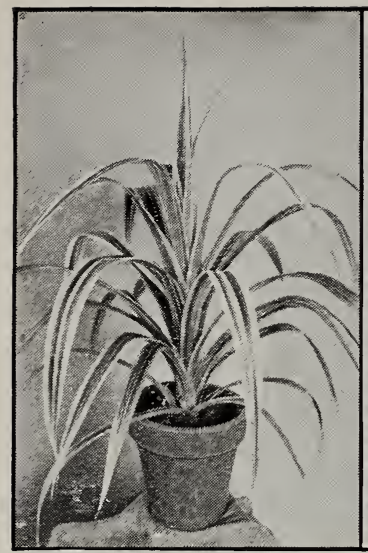

Pandanus Veitchii

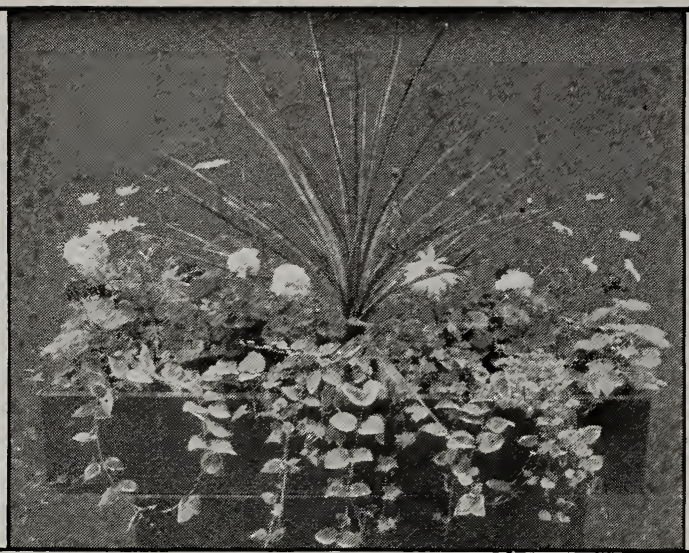

Window-Box Planting

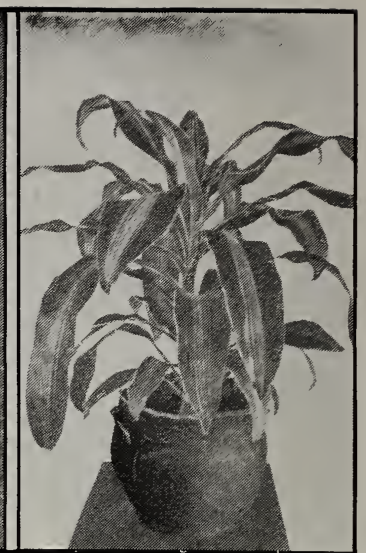

Dracæna

\section{Decorative Plants}

House plants are usually expected to grow and look well under very hard and trying conditions. Most plants require sunshine, moisture in the soil and in the air, a free movement of the air itself and good soil in which to grow and remain healthy. In the house good soil may be furnished, but the other things are of ten difficult to secure. The following list of plants contains many sorts selected purposely with the idea of meeting these unfavorable conditions and at the same time combining the necessary decorative effect in their form and appearance. In this class may be grouped Ficus, Pandanus, Vinca and Ophiopogon. In addition to giving satisfaction under trying conditions, they will respond to better treatment in more vigorous grown and greater beauty. See also Palms and Ferns.

ARALIA filicifolia. A shrubby plant with fern-like foliage, reaching a height of about 8 feet. Fine in all sizes.

Guilfoylei. A handsome, showy shrub for house or outdoor culture. Leaves green, margined with white. Each Per ro Nice plants...........\$0 $75 \$ \$ 6 \quad 50$ Extra-strong plants......... I oo 850

CROTONS. Shrubby plants with foliage variegated in many different brilliant shades. They require plenty of moisture and high temperatures. $\quad$ Each Per ro 4 -inch pots..........\$o $75 \$ \$ 600$ 6 -inch pots.............. I oo 850

DRACANA indivisa. This fine plant has long, narrow, graceful foliage. A fine variety for vases or porch-boxes, and may be grown outof-doors in southern Florida.

ensiformis. An excellent variety with medium green foliage. Fine for porch-boxes.

Lord Wolseley. Fine; bright red leaves.

terminalis. A very decorative variety, with crimson foliage, striped with pink and white. Does well under average house conditions; is also a fine summer porch plant.

Prices on Dracænas: $\quad$ Each Per ro 4-inch pots...........\$0 $75 \$ 650$ 6 -inch pots............... I oo 850

FICUS altissima. A splendid house plant, with large, roundish oblong leaves.

elastica. The common Rubber Plant with bright, shiny leaves. Will stand much abuse.
Prices on Ficus: $\quad$ Each Per Io I 2 to $\mathrm{I} 8$ inch........... $\$$ I oo $\$ 8$ 50 I 8 to 24 inch............ I 50 I2 00 2 to 3 feet................ 2 oo

GREVILLEA robusta (Australian Silk Oak). Young plants of this species are very fine for decorative purposes. (See page 55.)

OPHIOPOGON japonicus. A low-growing plant with dark green, grass-like foliage. A good plant for window and porch-boxes. Each Per Io 3 -inch pots............\$O $25 \quad \$ 200$ 4 -inch pots............ 50 400

PANDANUS Veitchii. One of the finest decorative plants, with sword-like, sharp-pointed foliage; green striped with creamy white.

$$
\begin{aligned}
& 4 \text {-inch pots...........\$I oo } \$ 8 \text { 50 } \\
& 6 \text {-inch pots.............. } 2 \text { oo }
\end{aligned}
$$

SANSEVIERIA laurentii. A variety of Bow String Hemp with beautifully banded dark light green sword-like leaves, with a yellow stripe on the margins. Adapted for culture under trying concitions. $75 \mathrm{cts}$. and $\$ \mathrm{I}$ each.

VINGA major variegata. A trailing plant with glossy green leaves, margined with creamy white. Flowers blue. One of the best plants for hanging-baskets, vases, and porch-boxes. minor. A dark green trailing plant, valuable for boxes and for cemetery planting.

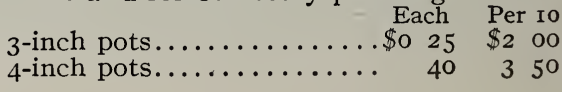




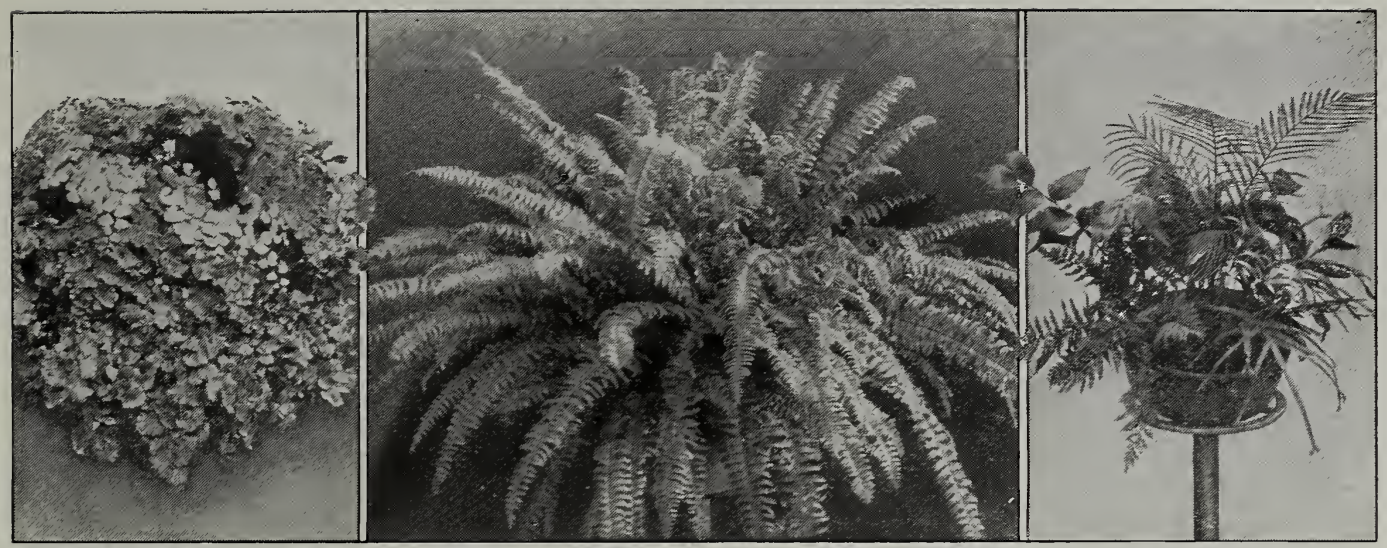

Adiantum

Boston Fern

Fern Dish

\section{Ferns and Asparagus}

For house decoration few plants surpass the Ferns for general use, both on account of their great beauty and the ease with which they may be kept in good condition. Many plants require much sunshine for their best development, but these are naturally at home in partial shade. The soil in which they are planted should be rich and well supplied with vegetable matter in the form of leaf mold. Provide good drainage and water freely. The varieties which we can furnish are among the verv best decorative varieties. They are well grown, vigorous, and healthy.

NEPHROLEPIS davallioides furcans (Staghorn Fern). Fronds 2 to 3 feet long, upright at first, later drooping. A fine decorative Fern. exaltata (Sword Fern). Stiff and upright; valuable for shady places in open grounds and for window-boxes.

bostoniensis (Boston Fern). A fine decorative Fern, very vigorous, and succeeds under trying conditions.

Dwarf Boston. A dwarf form of the largegrowing Boston Fern, with the same graceful habit and type of foliage.

elegantissima (Lace Fern). The small leaflets are divided into miniature fronds, giving both sides of the fronds a beautiful appearance.

John Wanamaker (The Wanamaker Boston Fern). Fronds long, narrow, and graceful.

Piersonii (Pierson's Boston Fern). The pinnæ are subdivided into small fronds making a graceful plumy plant.

robusta. A strong-growing crested form; makes a large-sized symmetrical plant.

Roosevelt. Pinnæ waved, giving the fronds a distinct appearance. A robust grower.

Scottii. A rather dwarf variety with spreading leaves, growing in compact clusters.

splendida. A very strong-growing variety, producing fronds of many different types.

Teddy Junior. Of vigorous dwarf growth, with wavy pinnæ and green fronds. Grows well under trying conditions.

Whitmanii. Resembles N.elegantissima, but the leaves are more open, fronds almost the same on both sides; dense growth.
Nephrolepis Whitmanii compacta. Leaves I 5 to 8 inches long. More compact in growth than Whitmanii. A very fine variety.

MAIDENHAIR FERN (Adiantum cuneatum). Beautiful, graceful drooping fronds.

Prices on the above fifteen varieties: 4-inch pots, $75 \mathrm{cts}$. each; larger sizes, $\$ 1, \$ 2$, and up

NEPHROLEPIS Goodii (Baby's Breath Fern). Specimen plants are fluffy and dainty, with fine feathery fronds.

Scholzellii (Crested Fern). The fronds are erect and arched. A very handsome variety, splendid for table decorations.

superbissima. The twisted, dark green fronds look as if numerous small Ferns were growing out of them.

Prices on the above three varieties: 4-inch pots, $\$ 1$ each; larger sizes, $\$ 1.50$, and up

\section{FERNS FOR FERN DISHES}

These small or dwarf ferns are used for filling dishes for table decorations. Our stock includes the best varieties. $35 \mathrm{cts}$. each.

\section{ASPARAGUS}

Asparagus plumosus. A popular decorative plant with sprays of dark green feathery foliage. Suitable for shady places.

Sprengeri. Leaves narrow, dark green, branches drooping. Fine for hanging-baskets and porch-boxes. Grows well in shade.

Prices on Asparagus. Each Per ro 3 -inch pots ............ \$o $35 \quad \$ 3$ oo 4 -inch pots ............... 50 . 4 oo 


\title{
SOUTHERN PLANTING FACTS
}

\section{Planting Information}

The land on which trees are to be set should be thoroughly prepared before planting. Too frequently this important matter is neglected or poorly done, but it pays to give particular attention to this part of the work. It is easier to put the land in good condition before planting than after, and, if the trees are to bring the results desired, it must be done at some time. Generally it is best to clear the land a year in advance of planting, then grow a crop of cowpeas or velvet beans and turn it back into the soil in advance of planting. Good results may be secured without this, but it is a good plan to follow whenever possible.

\section{Staking}

After the land has been well plowed, harrowed and leveled, a 3- or 4-foot stake should be set where each tree is to stand.

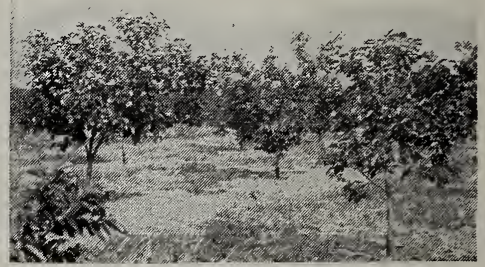

View in Persimmon orchard planted with our trees

\begin{abstract}
Laths make good stakes for this purpose. While a number of different plans may be used in spacing the trees, it is usually best to set them in squares or in rectangles (spaced a little farther apart nne way than the other).
\end{abstract}

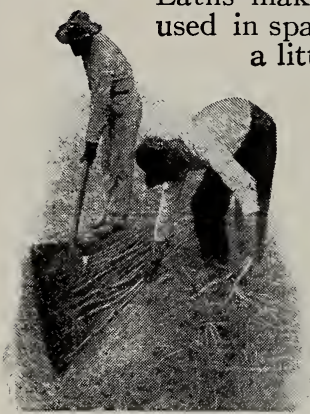

Heeling-in Peach trees

\section{Planting Distances}

The distance apart at which the trees should be set depends upon the character of the soil, the moisture it contains, the kind of trees and the ideas of the planter. Usually they should be given a goodly distance. A table of usual planting distances is given on the inside back cover page.

\section{Care of Trees on Arrival}

When the trees arrive, if everything is in readiness, they may be taken directly to the field and set out, taking the trees from the boxes as needed. If the number is large, or there is a delay of more than a few days, it is best to open up the boxes or bales and heel-in the trees. This is done by digging a trench deep enough to accommodate the roots nicely, straight down on one side, sloping out to the ground-level on the other. In this trench place the roots, the tops in slanting position, cover with earth, packing well among the roots, use some water, and cover the tops with packing material, straw or grass, to shade them. From this heeling-in place they may be taken for planting, and carefully protected from the sun with damp burlap until placed in the holes.

\section{Digging Holes-Fertilizers}

It is best to dig the holes just in advance of planting to prevent drying or baking; also loss of moisture. The holes should be made 6 inches wider and deeper than necessary to accommodate the roots. Place the top-soil in a pile by itself when the holes are dug. Commercial fertilizer

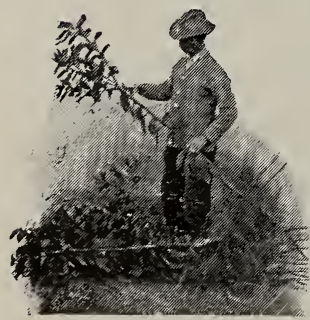

Pruning tops of Grapefruit trees analyzing about 6 per cent phosphoric acid, 4 per cent ammonia and 2 per cent potash may be used at the rate of one-half to one pound per tree, thoroughly mixed with the

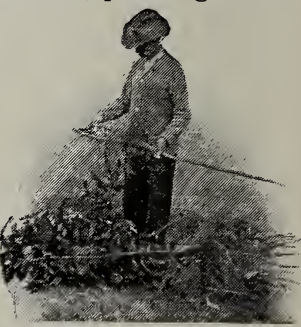

Root-pruning Grapefruit trees top-soil in filling in around the roots. We do not recommend the use of stable manure in the holes, though on pecans, persimmons, roses and ornamentals in general, it may be used to advantage as a mulch after planting, when well rotted.

\section{Pruning}

Some kinds of nursery trees must be pruned before shipping. Others are not pruned. It is a safe rule with practically all plants that the tops should be cut back before planting. Any broken roots should be trimmed off before the trees are set. 


\section{GLEN SAINT MARY NURSERIES}

Planting Information

\section{Setting the Trees}

Set the trees the same depth they stood in the nursery rows. The exact point can be determined by the earth-marks, or the "collar." Citrus trees, particularly, are very much injured by too deep planting, and it is a safe rule with all trees and shrubs to set them a little higher than they grew rather than lower. Spread out the roots carefully by hand, and pack the earth well around them. When the hole is three-quarters filled up, pack thoroughly

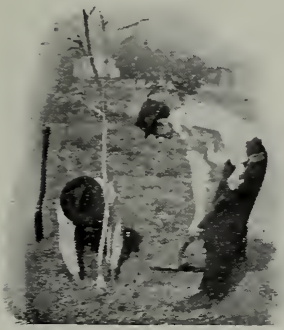

Planting a shade tree with the feet. This is important. More trees are lost from loose packing than from any other cause. After packing thoroughly, and before the hole is quite filled up, pour in water, especially if the soil is dry. As the water sinks down into the earth, it

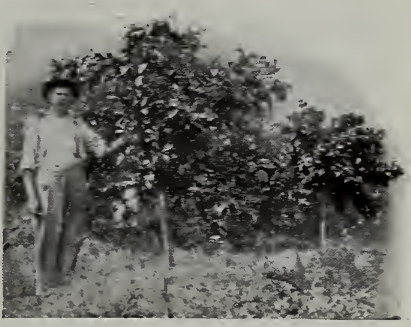

One of our 2-year-old Grapefruit trees, eleven months after planting, in the grove of Mr. John H. Derby, Rockledge, Florida. helps to pack the soil in all the small corners among the roots. When the water has sunk away, fill up the balance of the hole, fack again with the feet, straighten up the tree and level off. If the weather and soil are dry it is often an excellent plan to bank up around the tree with dry soil This prevents evaporation of moisture from the tree, keeps it steady in the ground, and is a great protection. This bank can be removed later on after it has served its purpose. During the winter, banking is a good protection against frost.

\section{General Care}

After carefully planting trees or shrubs they should receive such care and attention as will keep them in thrifty growing condition, and, if the best results are desired, they should never be allowed to become stunted in their growth. To bring about this condition they must be cultivated frequently, fertilized from time to time, and kept free from insects and diseases. Only those who give their trees the care they require can hope to secure the maximum results from their plantings. Consult your successful neighbors.

\section{Cultivation}

The ground around newly set plants must be kept free from weeds, because a growth of weeds deprives the trees of needed moisture and plant-food. Lawn specimens may be cared for by simply cutting out the turf in a circle of 2 feet radius around the trees, and keeping the circles well cultivated. Young orchard trees may be handled by cultivating a narrow strip 3 to 5 feet wide on each side of the tree-rows and the remainder of the ground (not cultivated) should be planted with a cover-crop to shade the soil and improve its condition when it is plowed under. It is best to continue the cultivation of the narrow strip throughout the season, or well up into autumn. Of course, if heavy rains occur, cultivation of young trees may at times be cmitted, but even then weeds must not be allowed to grow up around the trees, thereby shading them to an injurious degree.

The cultivation of older trees differs in some particulars from that given young trees. In the first place cultivation should begin in spring some time before the trees start into growth and should be continued at intervals of ten days or two weeks throughout the spring months up until about June I5 or July I. A cover-crop should then be given possession of the ground until autumn. The best cover-crops in the lower South are beggarweed, cowpeas and velvet beans. In spring, the whole surface of the ground should be cultivated, and if the weather is dry, cultivation should be given at more frequent intervals.

The most important objects of cultivation are to preserve a dust mulch and conserve moisture. The best cultivation tools are a disc harrow, an extension disc, an Acme harrow and, for heavy lands, a spring-tooth harrow. The plow for cultivating is not usually required. Its use comes when the cover-crop is turned under or in the fall.

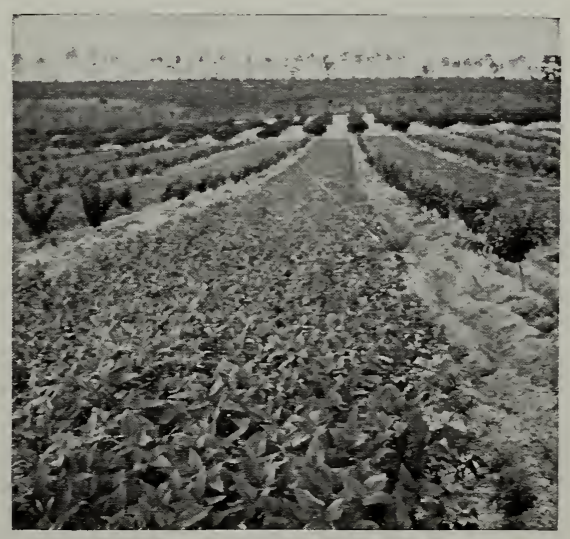

Plan for cover-crop and cultivation of young orchard 


\section{SOUTHERN PLANTING FACTS}

\section{Planting Information}

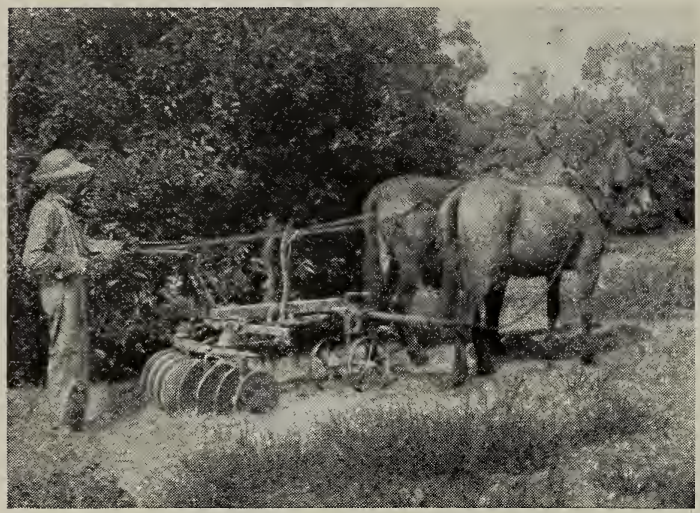

Disc harrow at work in an Orange grove

required on shade trees, for instance, it is a g in diameter. Young fruit trees may be given two or three pounds for each year of age, and fruiting trees have to be fertilized according to their condition and the crop indications.

If a young orange tree received one-half pound at time of planting in January, it should receive a pound in March, another in June, and another in September. In its second year, it should be fertilized in February, April, June and September, giving about one pound and a half at each application. After the second year, there should be a gradual increase as the trees become older; those who secure best results fertilize liberally. Something depends on the character of the soil.

In fertilizing young trees, the fertilizer should be scattered in a band 2 feet wide, beginning back 6 inches from the trunk. As they become older, the fertilizer should be spread out toward the ends of the branches, and in old orchards or groves it should be broadcasted over the whole surface as the roots make their way into all parts of the soil. After applying fertilizer the ground should be cultivated.

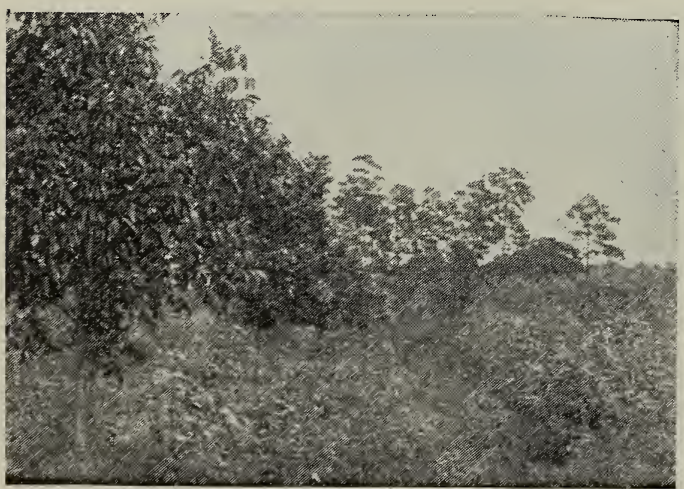

Cover-crop of beggarweed in a Pecan orchard

\section{Fertilizers}

The fertilizer already recommended for use at time of planting will be found about right for young trees and, under most conditions, its use may be continued until the trees are well grown and commence to bear. On shade trees and shrubs its use may be continued throughout. When fruit trees begin to bear, the composition of the fertilizer applied should be changed. The amount of potash should be increased. In general, it will be found that a fertilizer containing 2 per cent ammonia, 6 per cent phosphoric acid, and an increased amount of potash will be about right. Of course, the composition of the fertilizer has to be varied to meet special conditions.

The general tendency in the use of commercial fertilizers is to make frequent applications of plan to use from one to two pounds for each inch

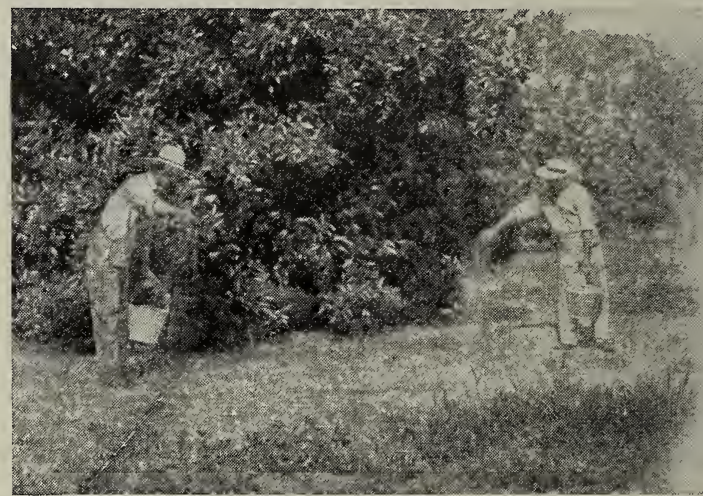

Distributing fertilizer around the outside branches small amounts. In arriving at the quantities

\section{Insects and Diseases}

These must be watched for and guarded against. Dead branches should be removed from the tops of trees and burned. They often contain spores of diseases or have become the breedingplaces of noxious insects. In some localities many insects may be controlled effectively through the agency of friendly fungi. In others it is necessary to spray as well. In a general way it will be found that bordeaux mixture is effective against fungi, lime-sulphur wash as a winter spray against scale insects and fungi on deciduous trees, rust mite, purple mite and red spider on citrus; arsenate of lead against biting or chewing insects, and whale-oil soap or miscible oil against sucking insects such as white fly and against various scale insects. 


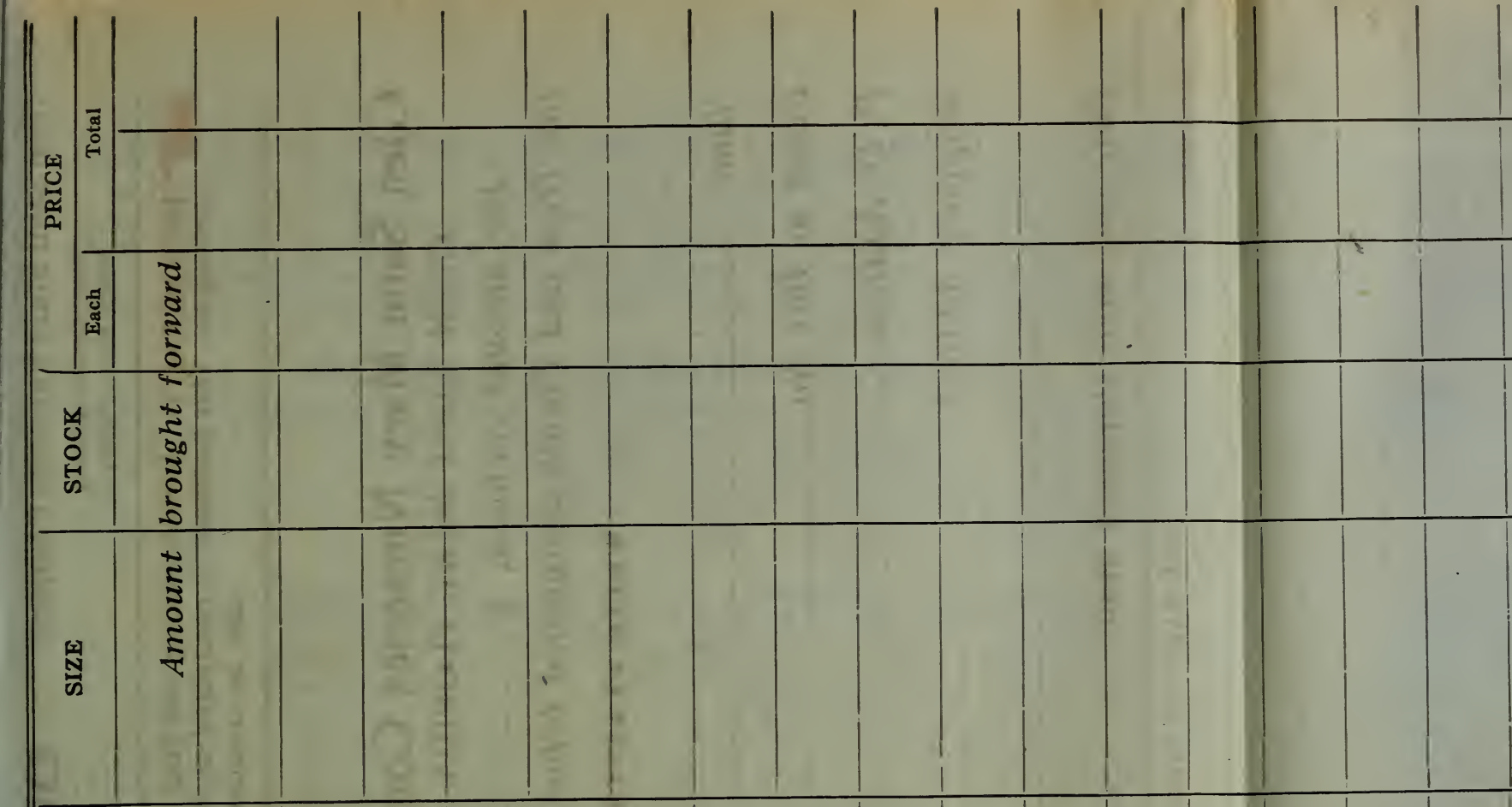




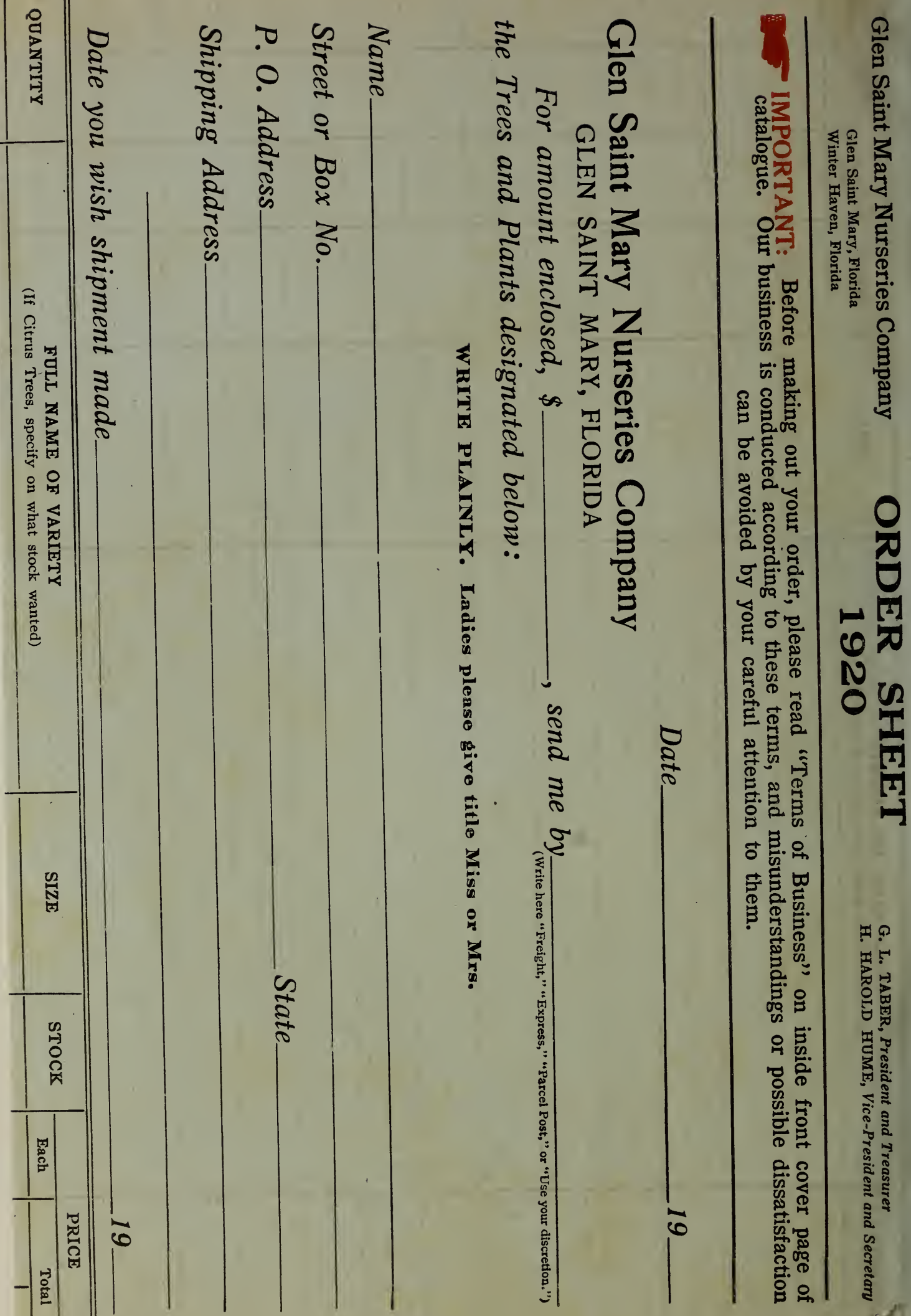




\section{LARGE-SIZED TREES AND SHRUBS FOR IMMEDIATE RESULTS}

In the foregoing pages of our Catalogue we have listed the regular sizes of trees and plants. Very frequently our customers are interested in large-sized specimens with which to secure quicker effects from their plantings. We are able to furnish these in a number of different sizes and varieties, and we are prepared to move them with large balls of earth about the roots. We shall be pleased to furnish descriptions and prices upon request, stating size and kind desired.

\section{PROPER DISTANCES FOR PLANTING}

Oranges on common stocks...25 to $30 \mathrm{ft}$. each way Oranges on $C$. trifoliata...... I 8 to $20 \mathrm{ft}$. each way Kumquats.............. Io to I2 $\mathrm{ft}$. each way Peaches and Apples......... I8 to $20 \mathrm{ft}$. each way Plums.................. I5 to I $8 \mathrm{ft}$. each way Japan Persimmons.......... I5 to $20 \mathrm{ft}$. each way
Pears, Le Conte..........25 to $30 \mathrm{ft}$. each way Pears, General varieties.....20 to $25 \mathrm{ft}$. each way Grapes, Bunch varieties..... 8 to Io $\mathrm{ft}$. each way Grapes, Muscadine type..... I 8 to $25 \mathrm{ft}$. each way

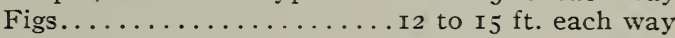
Pecans.............40 to $50 \mathrm{ft}$. each way

\section{NUMBER OF TREES OR PLANTS TO THE ACRE}

\begin{tabular}{|c|c|c|c|}
\hline $\begin{array}{l}\text { Distance } \\
\text { apart, feet }\end{array}$ & $\begin{array}{l}\text { Distance } \\
\text { apart, feet }\end{array}$ & $\begin{array}{l}\text { Distance } \\
\text { apart, feet }\end{array}$ & $\begin{array}{l}\text { Distance } \\
\text { apart, feet }\end{array}$ \\
\hline 8 by $8 \ldots \ldots 6680$ & I3 by $13 \ldots \ldots \ldots 257$ & Is by I $8 \ldots \ldots \ldots$ I34 & 30 by 30 . \\
\hline 9 by $9 \ldots \ldots \ldots . .537$ & I4 by I $4 \ldots \ldots \ldots 222$ & Ig by $19 \ldots . . \ldots . . .120$ & 35 by 35 . \\
\hline Io by Io.. & I5 by I5 $\ldots \ldots$ & 20 by 20. & 40 by $40 \ldots$ \\
\hline II by II........360 & I6 by $16 \ldots \ldots \ldots$ I 70 & 22 by $22 \ldots$ & 45 by $45 \ldots$ \\
\hline I2 by I $2 \ldots \ldots \ldots \ldots 302$ & I 7 by I $7 \ldots \ldots \ldots$ I5o & 25 by $25 \ldots \ldots \ldots$ & 50 by $50 \ldots$. \\
\hline
\end{tabular}

\section{CONTENTS}

PAGE

Terms of Business................................ cover

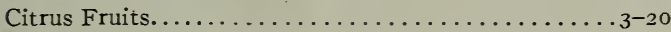

Nut Trees.........................

Deciduous Fruits......................... $25-39$

Tropical and Sub-Tropical Fruits................ 40

Roses........................... . . . 45

Trees and Shrubs Shipped with Balls of Earth.....46, 47

Arborvitæs and Other Conifers.................. 48

Shrubs and Hedge Plants................ 49-54

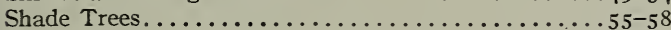

Palms and Cycads......................
Bamboos, Grasses, Sedges. $\ldots \ldots \ldots \ldots \ldots \ldots \ldots$

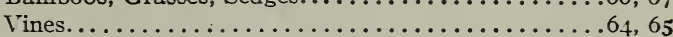

Bedding Plants.........................6. $66_{2}$

Bulbous and Tuberous Plants................68

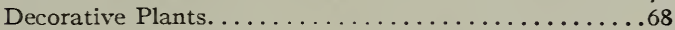

Ferns and Asparagus.....................69

Planting Information..................... $70_{72}$

Large-sized Trees and Shrubs for Immediate Results..

Third cover

Proper Distances for Planting............ Third cover Number of Trees or Plants to the Acre........ Third cover

\section{INDEX}

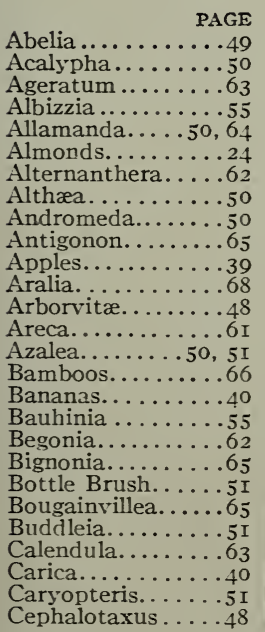

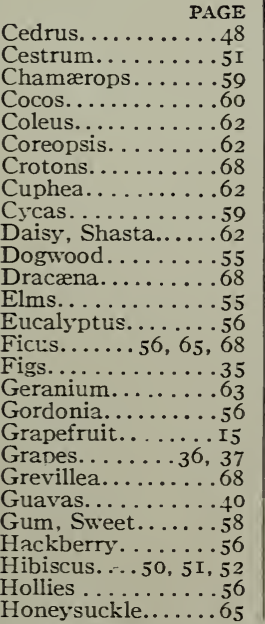

\begin{tabular}{|c|c|}
\hline PAGE & AGE \\
\hline .52 & Oleander... \\
\hline ypericum. & Ophiopogon. \\
\hline ex. . & Oranges... \\
\hline y, English & Oreodoxa. \\
\hline y, Japan.......65 & Pandanus... \\
\hline sminum.... & Papaya... \\
\hline amine, Yellow.. 65 & Parkinsonia. . . . 5 57 \\
\hline$\ldots \ldots 48$ & Peaches....... \\
\hline ntia..........6 & Pears...........36 \\
\hline qquats.......20 & Pecans. . . . 2I-24, 57 \\
\hline tania........6. & Persimmons, Japan \\
\hline rel, Cherry ....55 & $29-32$ \\
\hline ons........ I4-I9 & Phœenix. \\
\hline cothoë........552 & Phyllanthus.. \\
\hline ........ I9 & Pittosporum ......53 \\
\hline$\ldots \ldots 65$ & Plums........33, 34 \\
\hline olia......52, 57 & Poinsettia.... \\
\hline aviscus.....553 & Pomegranates. \\
\hline le... & Pomegranate, Flow- \\
\hline k Orange...... 53 & ering. . \\
\hline berries.....38, 39 & Pomelo..... \\
\hline le, Crape.....5 I & Poplar. \\
\hline$\ldots \ldots \ldots 57$ & Privet....... \\
\hline Silk & yrus.... \\
\hline$\cdots \cdots .33$ & Raphiolepis.......54 \\
\hline
\end{tabular}

PAGE Red-Bud.........58 Retinospora.......48 Rhapidophyllum. .60 Rhyncospermum ..65 Roses........4 $1-45$ Rudbeckia.......63 Sabal........60,6I Salvia..........6 63 Sansevieria ......68 Seaforthia........6. 6I Spiræa............5t Spirea, Blue.....5 I Stokesia........63 Sycamores........58 Tea Plant........54 Umbrella, Texas...58 Verbena........6.63 Viburnum...........54 Vinca...........6. 68 Violet.............6. 63 Virginia Creeper...65 Vitex..........54 Walnuts. . . . . . 2t Washingtonia.....6. 6 I Willow, Flowering. .56 Wistaria........65 


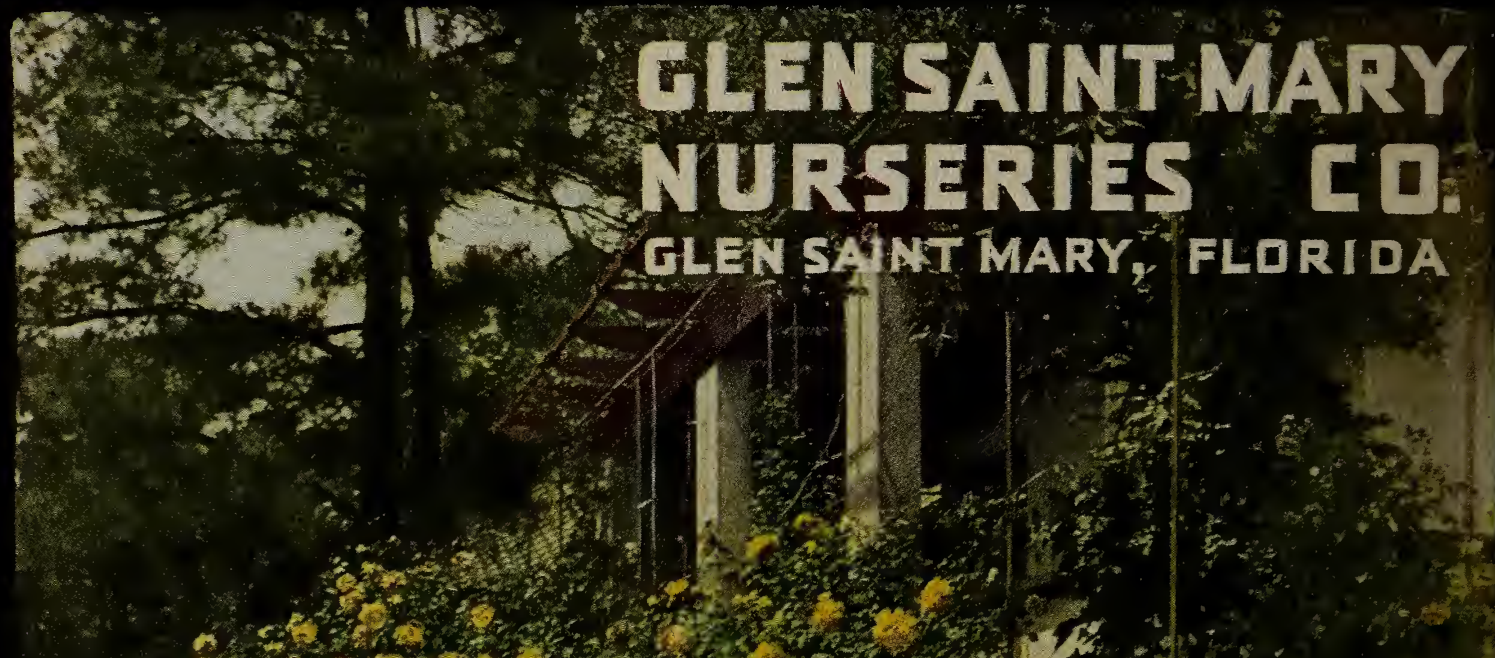

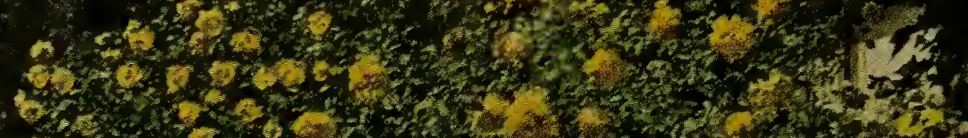

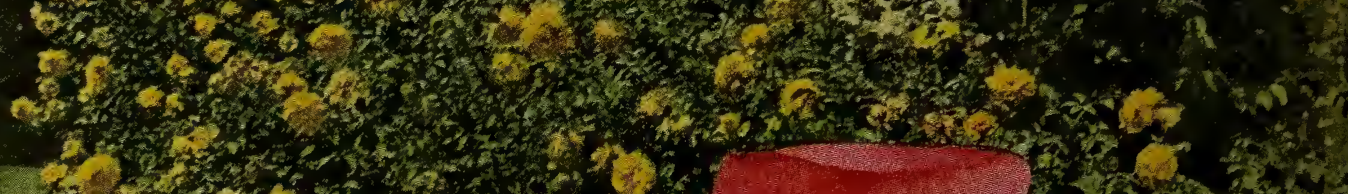

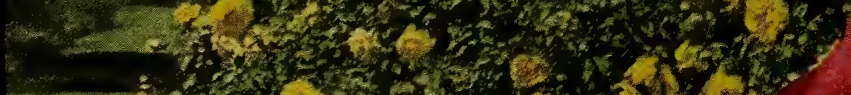

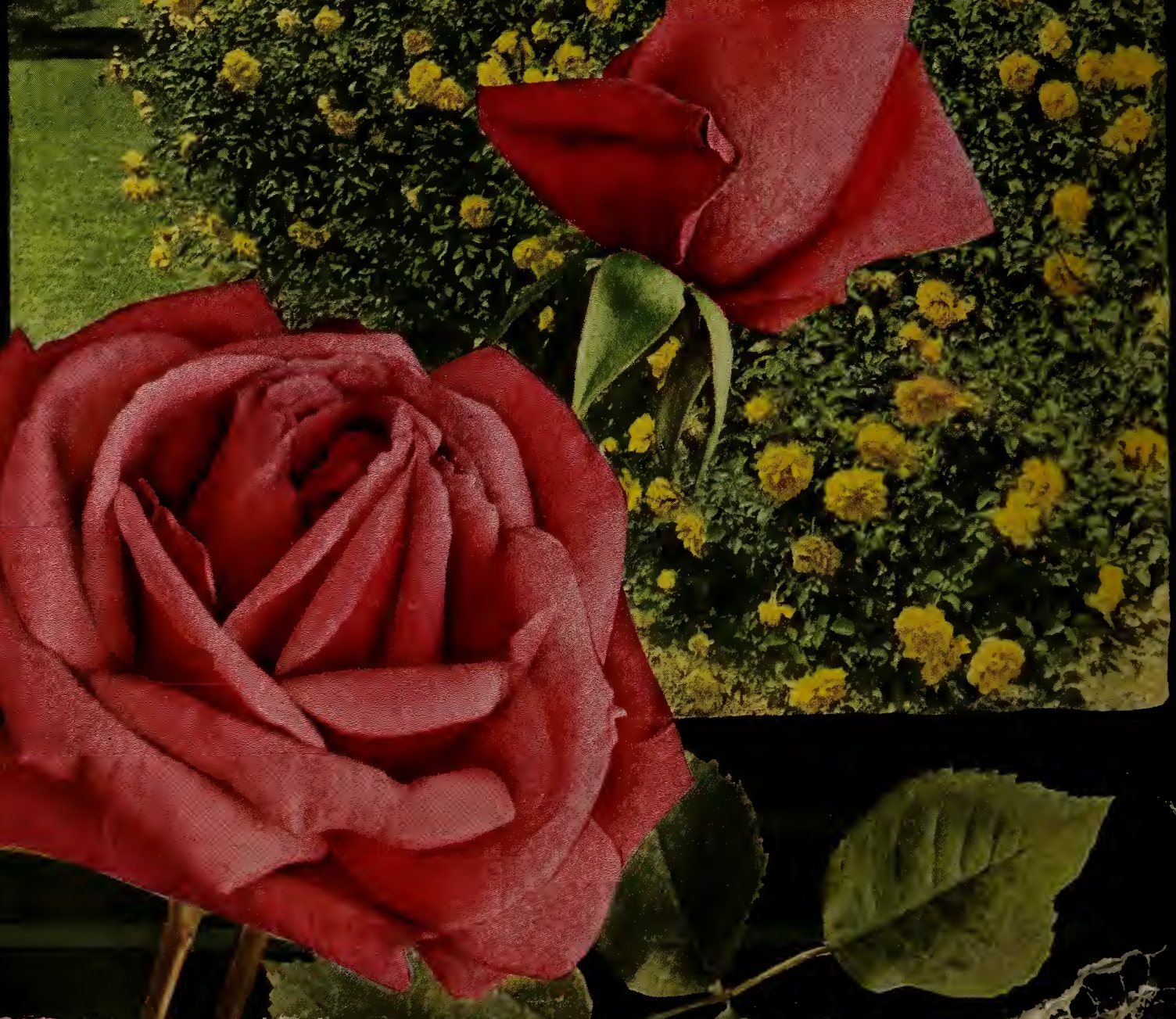

